NUREG/CR-4097

SAND84-2630

RV

Printed March 1985

REEEVED BY OSTI JUL 01085

\title{
Test Series 4: Seismic-Fragility Tests of Naturally-Aged Exide EMP-13 Battery Cells
}

Lloyd L. Bonzon, Donald B. Hente

Prepared by

Sandia National Laboratories

Albuquerque, New Mexico 87185 and Livermore, California 94550

for the United States Department of Energy

under Contract DE-AC04-76DP00789

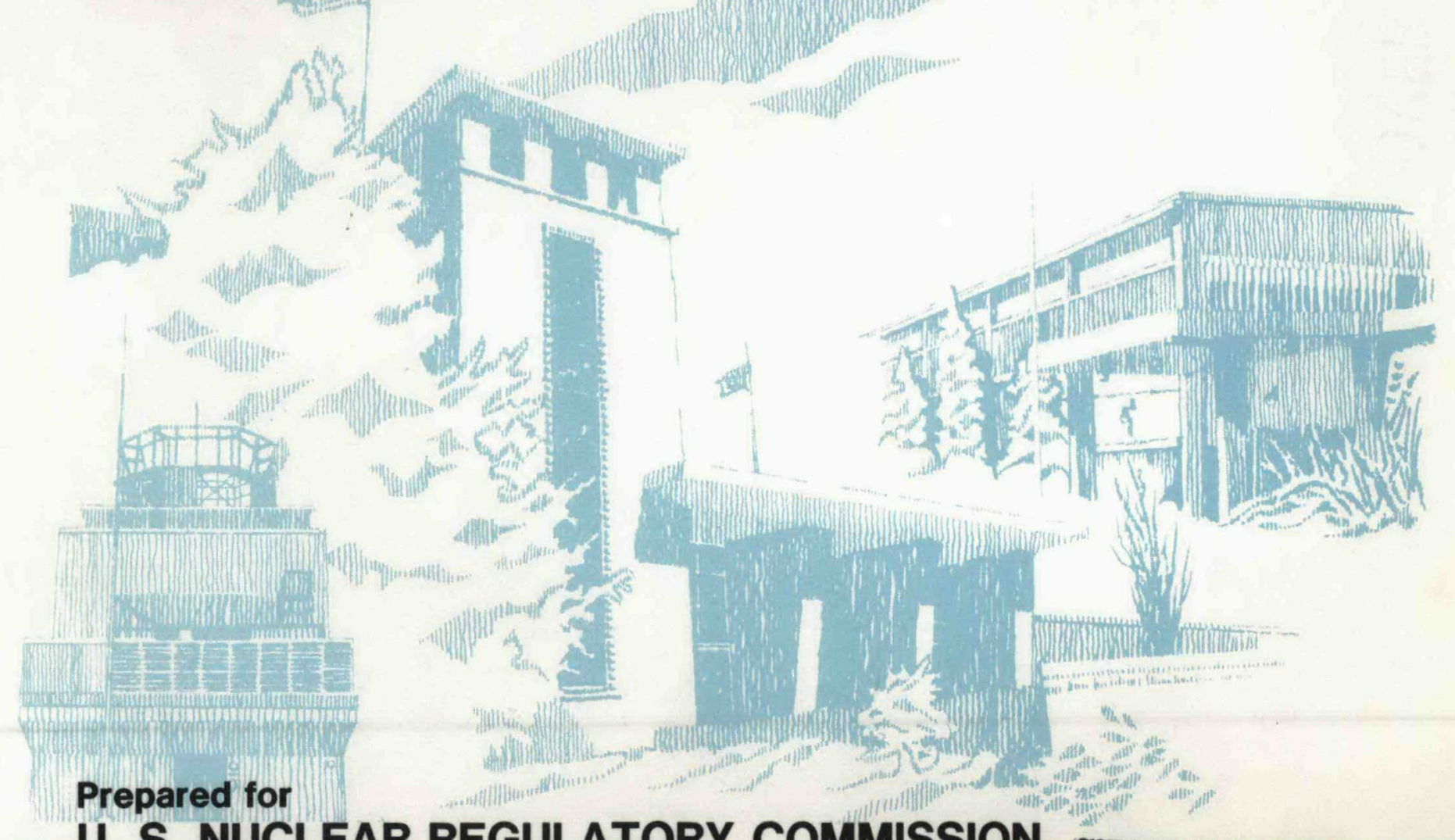




\section{DISCLAIMER}

This report was prepared as an account of work sponsored by an agency of the United States Government. Neither the United States Government nor any agency Thereof, nor any of their employees, makes any warranty, express or implied, or assumes any legal liability or responsibility for the accuracy, completeness, or usefulness of any information, apparatus, product, or process disclosed, or represents that its use would not infringe privately owned rights. Reference herein to any specific commercial product, process, or service by trade name, trademark, manufacturer, or otherwise does not necessarily constitute or imply its endorsement, recommendation, or favoring by the United States Government or any agency thereof. The views and opinions of authors expressed herein do not necessarily state or reflect those of the United States Government or any agency thereof. 


\section{DISCLAIMER}

Portions of this document may be illegible in electronic image products. Images are produced from the best available original document. 


\section{NOTICE}

This report was prepared as an account of work sponsored by an agency of the United States Government. Neither the United States Government nor any agency thereof, or any of their employees, makes any warranty, expressed or implied, or assumes any legal liability or responsibility for any third party's use, or the results of such use, of any information, apparatus product or process disclosed in this report, or represents that its use by such third party would not infringe privately owned rights.

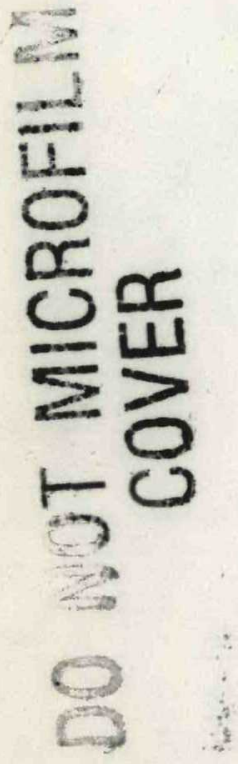

\section{Available from}

GPO Sales Program

Division of Technical Information and Document Control

U.S. Nuclear Regulatory Commission

Washington, D.C. 20555

and

National Technical Information Service

Springfield, Virginia 22161 
NUREG/CR-4097

TI85 013843

SAND8 4-2630

RV

TEST SERIES 4: SEISMIC-FRAGILITY TESTS OF NATURALLY-AGED EXIDE EMP-13 BATTERY CELLS

\author{
March 1985 \\ Lloyd L. Bonzon \\ Donald B. Hente \\ Sandia National Laboratories \\ Albuquerque, New Mexico 87185 \\ Operated by \\ Sandia Corporation \\ for the
}

U.S. Department of Energy

\author{
Appendices Prepared by \\ Bharat M. Kukreti \\ Jerry Schendel \\ James D. Tulk \\ W. John Janis \\ David A. Black \\ Gordon D. Paulsen \\ Brian D. Aucoin \\ Ontario Hydro
}

Toronto, Ontario. Canada

Performed under Sandia Contract No. 47-4077

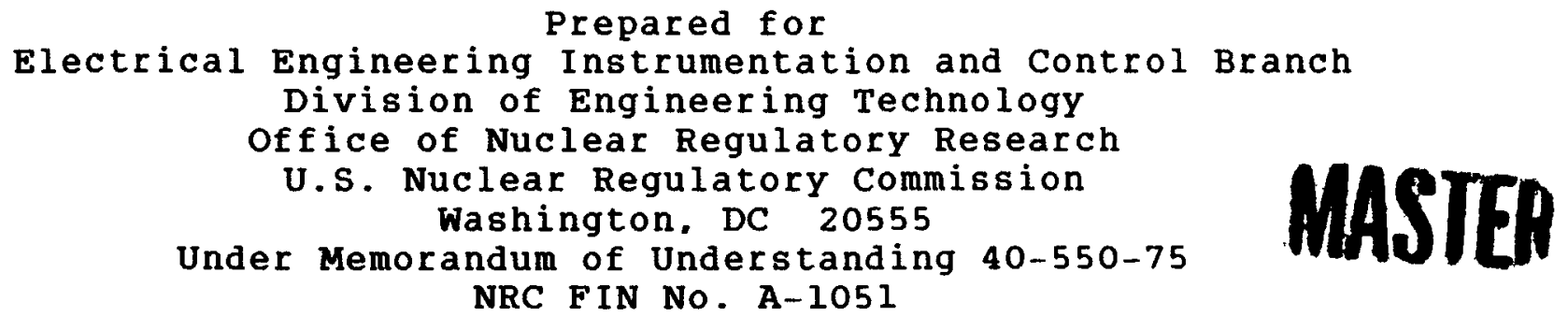

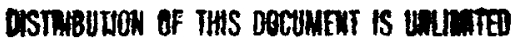

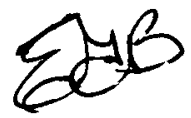


Related Publications in this series

- L. L. Bonzon and D. B. Hente, "Test Series 1:

Seismic-Fragility Tests of Naturally-Aged Class 1E Gould NCX-2250 Battery Cel1s." SAND84-1737. NUREG/CR-3923, Sandia National Laboratories. Albuquerque, New Mexico, September 1984 .

- L. L. Bonzon and D. B. Hente, "Test series 2:

Seismic-Fragility Tests of Naturally-Aged Class lE Exide FHC-19 Battery Cells." SAND84-2628. NUREG/CR-4095. Sandia National Laboratories. Albuquerque. New Mexico, March 1985.

- L. L. Bonzon and D. B. Hente. "Test Series 3:

Seismic-Fragility Tests of Naturally-Aged Class IE C\&D LCU-13 Battery Cells." SAND84-2629. NUREG/CR-4096. Sandia National Laboratories, Albuquerque, New Mexico, March 1985.

- L. L. Bonzon and D. B. Hente. "Test series 4:

Seismic-Fragility Tests of Naturally-Aged Exide EMP-13

Battery Cells." SAND84-2630. NUREG/CR-4097. Sandia National Laboratories. Albuquerque. New Mexico, March 1985.

- L. L. Bonzon and D. B. Hente. "Seismic-Fragility Baseline Tests of New Class IE Battery Cells," SAND84-263l. NUREG/CR-4098. Sandia National Laboratories. Albuquerque, New Mexico. (To be published.)

- L. L. Bonzon and D. B. Hente, "Age-Related Degradation of Naturally-Aged Class 1E Battery Cells." SAND84-2632, NUREG/CR-4099, Sandia National Laboratories, Albuquerque, New Mexico. (To be published.) 


\section{ABSTRACT}

The seismic-fragility of naturally-aged nuclear station safetyrelated batteries is of interest for two reasons: (1) to determine actual failure modes and their thresholds and (2) to determine the validity of using the electrical capacity of individual cells as an indicator of the "end-of-life" of a battery if subjected to a seismic event. This report, the fourth in a test series of an extensive seismic research program. covers the testing of 27-year old lead-antimony Exide EMP-13 cells from the Shippingport Atomic Power station.

The Exide cells were tested in two configurations using a triaxial shake table: single-cell tests, rigidly mounted: and multicell (five-cell) tests, mounted in a typical battery rack. In general the test philosophy was to monitor the electrical properties (including discharge capacity) of cells through a graduated series of increasing zero period accelerations (ZPA) g-level steps until either the shake-table limits were reached or until electrical "failure" of the cells occurred.

A total of nine electrically active cells was used in the two different cell configurations. None of the nine cells failed during the actual seismic tests when a range of ZPAs up to $1.5 \mathrm{~g}$ was imposed. Subsequent discharge capacity tests of five of the cells showed. however. that none of the cells could deliver the accepted standard of $80 \%$ of their rated electrical capacity for three hours. In fact, none of the five cells could deliver more than a $33 \%$ capacity.

Two of the seismically tested cells, and one untested. lowcapacity cell were disassembled for examination and metallurgical analyses. The inspection showed the cells to be in poor condition. The negative plates in the vicinity of the bus connections were extremely weak, the positive buses were corroded and brittle, negative and positive active material utilization was extremely uneven, and corrosion products littered the cells. These conditions, plus loss of negative grid material. clogged electrolyte channels, and positive plate surfaces choked with positive grid corrosion products all contributed to the low postseismic capacities. 
CONTENTS

$\underline{\text { Page }}$

Executive summary. . . . . . . . . . . . . . . . . . 1

l.o Background. . . . . . . . . . . . . . . . . . . 2

1.1 General . . . . . . . . . . . . . . . . . . 2

1.2 Historical and Programmatic Perspective . . . . . 2

2.0 Program Objectives. . . . . . . . . . . . . . . . . . 2

2.1 Evaluation of Battery Aging Methodologies. . . . 2

2.2 Seismic-Fragility Testing of Batteries. . . . . . 3

3.0 Approach and Report Format. . . . . . . . . . . . 3

3.1 Report Format . . . . . . . . . . . . . . . . . 4

4.0 Seismic-Fragility Tests of

Naturally-Aged Exide EMP-13 Cells. . . . . . . . . . . 5

4.1 Cell selection and Condition. . . . . . . . . . 5

4.2 Results During Seismic-Fragility Tests. . . . . . 5

4 .3 Postseismic Capacity Tests. . . . . . . . . . . . 7

4.4 Posttest Disassembly and Evaluation. . . . . . . 8

5.0 Conclusions . . . . . . . . . . . . . . . 9

6.0 References. . . . . . . . . . . . . . . 9

Appendices . . . . . . . . . . . . . . . . . . . . . A-i 

This work was performed at the ontario Hydro Research Center, Toronto. Ontario. Canada, under Sandia National Laboratories (SNL) contract 47-4077. It covers the period from July 1 , through December 31, 1984. The SNL technical project monitors are Lloyd L. Bonzon and Donald B. Hente.

The overall development and execution of this program were carried out by Mr. B. M. Kukreti assisted by Mr. J. Schendel of the Electrical Design Department. Dr. James D. Tulk of the Applied structural and Solid Mechanics section. Mechanical Research Department. provided the expertise in seismic technology and coordinated the research activities. Messrs. D. A. Black and G. D. Paulsen of the Mechanical Testing and Development Section. Mechanical Research Department, provided expertise in seismic testing. Messrs. W. John Janis and B. D. Aucoin of the Chemical Research Department performed the seismic testing and the subsequent cell disassembly. 


\section{EXECUT IVE SUMMARY}

The seismic-fragility of naturally-aged nuclear station safetyrelated batteries is of interest for two reasons: (1) to determine actual failure modes and their thresholds and (2) to determine the validity of using the electrical capacity of individual cells as an indicator of the "end-of-life" of a battery if subjected to a seismic event. This report. the fourth in a test series of an extensive seismic research program. covers the testing of 27-year old lead-antimony Exide EMP-13 cells from the Shippingport Atomic Power station.

The Exide cells were tested in two configurations using a triaxial shake table: single-cell tests, rigidly mounted: and multicell ( $f$ ive-cell) tests. mounted in a typical battery rack. In general the test philosophy was to monitor the electrical properties (including discharge capacity) of cells through a graduated series of increasing zero period accelerations (ZPA) g-level steps until either the shake-table limits were reached or until electrical "failure" of the cells occurred.

A total of nine electrically active cells was used in the two different cell configurations. None of the nine cells failed during the actual seismic tests when a range of ZPAs up to 1.5 $g$ was imposed. Subsequent discharge capacity tests of five of the cells showed, however. that none of the cells could deliver the accepted standard of $80 \%$ of their rated electrical capacity for three hours. In fact. none of the five cells could deliver more than a $33 \%$ capacity.

Two of the seismically tested cells, and one untested, lowcapacity cell were disassembled for examination and metallurgical analyses. The examination showed the cells to be in poor condition. The negative plates in the vicinity of the bus connections were extremely weak, the positive buses were corroded and brittle, negative and positive active material utilization was extremely uneven, and corrosion products littered the cells. These conditions, plus loss of negative grid material. clogged electrolyte channels, and positive plate surfaces choked with positive grid corrosion products all contributed to the low posttest capacities.

This effort is a subpart of a broader program to evaluate the accelerated aging methods used in qualifying class IE batteries (e.g.. in IEEE std 535-1979). By seismic-fragility testing naturally-aged battery cells, the actual failure modes and their thresholds can be determined. This determination serves to focus the evaluation and development of other aging methods on those specific failure modes. thresholds, and locations that have been observed. 
Other activities that are in progress include: (1) "baseline" examination and seismic testing of new. same type, cells from the three manufacturers of Class $1 E$ batteries: (2) accelerated aging of new. same type, cells and subsequent seismic testing: (3) accelerated-aging of naturally-aged cells to an 18-year age and subsequent seismic testing: (4) compiling of typical nuclear plant required response spectra for comparison with the fragility levels experienced in these and follow-on tests; and (5) additional lead-chemistry evaluations of battery internal components.

\subsection{BACKGROUND}

\subsection{General}

The seismic-fragility of naturally-aged nuclear station safetyrelated batteries is of interest for two reasons: (1) to determine actual failure modes and their thresholds and (2) to determine the validity of using the electrical capacity of individual cells as an indicator of the "end-of-life" of a battery if subjected to a seismic event.

\subsection{Historical and Programmatic Perspective}

The concern over the seismic susceptibility of nuclear station safety-related batteries was generated by the number of battery problems that periodically had been reported in Licensee Event Reports (LERs). $1-8 *$ Following the problems reported at the Connecticut Yankee station. 8 the NRC conducted an investigation which concluded that aged batteries may be vulnerable to common-mode failures because of a seismic event. 9 The NRC then issued Information Notice 83-11. Possible Seismic Vulnerability of old Lead Storage Batteries on March 14, 1983, to make nuclear power plant personnel aware of the finding. 10 Increasing concern over the possible adverse behavior of aged batteries in seismic events resulted in the NRC-sponsored Qualification Testing Evaluation (QTE) research program initiating an effort to evaluate the adequacy of batteries to survive seismic acceleration levels. Il These series of reports are the initial efforts of that research program.

\subsection{PROGRAM OBJECTIVES}

\subsection{Evaluation of Battery Aging Methodologies**}

The overall research programl has seven main objectives:

\footnotetext{
* Reference 1 contains more detail on the historical and programmatic perspective.

** The overall program is discussed in greater detail in Reference 12 .
} 
1. To determine seismic failure modes and thresholds, primarily using naturally-aged cells.

2. To identify the dominant aging mechanism(s) through this testing experience. in conjunction with other test experience and expert evaluations.

3. To compare the response of naturally-aged cells to the response of new cells aged by the accelerated methods described in IEEE std. 535-1979 and to compare dominant failure modes in both cases.

4. To identify appropriate accelerated aging methodologies for the dominant failure mode(s).

5. To demonstrate those accelerated aging methodologies through a specific demonstration test program.

6. To make final recommendations for appropriate acceleratedaging methodology(ies) for nuclear station batteries.

7. To develop in situ testing methods which can predict the remaining age and seismic "tolerance" of batteries.

2.2 Seismic-Fragility Testing of Batteries*

The seven objectives of the overall program can be grouped into four subprograms or goals. Objectives $1-3$ relate to an effort to determine by test the actual failure modes and thresholds experienced in natural aging. Objectives $3-5$ relate to an effort to compare/correlate current accelerated-aging methods and to recommend. develop, and prove modified aging methods based on the dominant failure modes observed. Objectives 5-6 lead to recommended aging method changes and incorporation into appropriate standards and guides. Objective 7 will lead to a predictive technique to determine "end-of-qualified" life of batteries.

This report covers the fourth in a test series to determine the seismic-fragility of naturally-aged battery cells: thus, it corresponds to the subgroup defined by objectives $1-3$ above and continues the effort of the first test series. 1

\subsection{APPROACH AND REPORT FORMAT}

Naturally-aged. Class IE, battery cells have been obtained from four nuclear power stations in the United states and sent to the

* The specifics of the seismic-fragility testing program are discussed in greater detail in Reference 13. 
Ontario Hydro Research Center for cell conditioning and subsequent seismic testing and analyses. All three manufacturers of Class $1 E$ batteries are represented among the four groups of cells obtained. The Test Series 1 report discussed the results of testing 12-year old Gould NCX-2250 battery cells. The Test Series 2 report discussed the results of testing 10-year old Exide FHC-19 cells. The Test series 3 report discussed the results of testing 10-year old C\&D LCU cells. This report discusses the results of testing 27-year old Exide EMP-13 cells obtained from the shippingport Atomic Power station. (No preference of treatment for testing or suspected failure should be implied from order of testing: the cells were tested in the order received.)

The details of the testing are summarized in the Appendices to this report. The generic approach followed this pattern: cell conditioning and pretest electrical capacity measurements were made: cells were exposed to simulated seismic (fragility) tests in both single and multicell configurations: posttest electrical capacity checks were made on cells which "survived": selected cells were disassembled and evaluated; and the results were analyzed and reported.

\subsection{Report Format}

Ontario Hydro staff performed all testing and analyses: their results, presented in four stand-alone reports, are included as Appendices:

A: Seismic Testing of Naturally Aged Exide EMP-13 station Battery Cells

B: Seismic Testing of Shippingport Nuclear Power station Batteries-Cell Inspection and Capacity Tests

C: Seismic Testing of Exide Aged Batteries

D: Seismic Testing of Aged Shippingport Nuclear Power Plant Batteries

Appendix $A$ is the collection and summary of the complete ontario Hydro effort along with results and conclusions sections.

Appendix B describes the preseismic cell conditioning, pre- and postseismic electrical capacity tests, and the results of both the single and multicell configuration tests and cell disassembly. Addendum 1 to Appendix B provides cell specifications provided by the battery manufacturer: Addendum 2 provides discharge data obtained during the seismic tests: and Addendum 3 provides the calculations to convert discharge times at the 1 -hour rate to the 3 -hour rate. 
Appendix $C$ and $D$ report on the single and multicell configuration testing. respectively. Both reports describe the test procedures followed. the test equipment used, and interpret the results of the tests. Figures show the response spectrum in each of the $X, Y$, and $Z$ axes from accelerometers located both on a terminal post of the cell and on the base of the shaketable mounting jig.

In addition. Sections 4 and 5, which follow, draw from the Appendices the salient results and conclusions.

\subsection{SEISMIC-FRAGILITY TESTS OF NATURALLY-AGED EXIDE, EMP-13, CELLS}

\subsection{Cell selection and condition}

After the Shippingport Atomic Power station was scheduled for decommissioning. Department of Energy staff released 20 randomly selected 27-year old EMP-13 cells for this test program.

Because of shipping damage and low electrolyte levels, eight of the cells were discarded when received. The remaining 12 cells were placed on an equalizing and then a floating charge. Subsequent discharge capacity measurements showed that all cells had lost capacity while in service but that nine cells still had a rated electrical capacity of better than $80 \%$ as measured in a standard three-hour test. The other three cells were rejected for seismic testing but one was disassembled to observe internal damage. Thus the cells used for these seismic tests were not degraded to a beyond an "end-of-life" condition.

\subsection{Results During Seismic-Fragility Tests}

The Appendices describe the test methods, results, and analyses in detail. Only the results are highlighted here, as summarized in Tables 1 and 2. As noted previously, the cells in both cell configurations were exposed to a graduated series of increasing ZPA g-level steps until "failure" of the cells occurred or the limits of the shake table were reached. No electrical or mechanical failure modes were noted for either the single or multicell configuration at any of the acceleration levels attained.

The ZPA Response Levels are the zero period accelerations of a normalized spectrum fitted to the experimental data over the 4 to $33 \mathrm{~Hz}$ range. The ZPA is used to express the intensity of the seismic motion of a typical seismic environment. The ZPAs shown are for the spectra when the shake table limits were reached.

The single cells listed in Table 1 were rigidly mounted to the shake table in a jig designed to minimize relative motion between the table and the cell jar. This rigid mounting was 


\section{Table 1}

Seismic-Fragility Test Results

single-Cell Tests

\begin{tabular}{|c|c|c|c|}
\hline $\begin{array}{l}\text { Cell } \\
\text { No. }\end{array}$ & $\begin{array}{l}\text { Run } \\
\text { Sequence* }\end{array}$ & $\begin{array}{l}\text { ZPA Response } \\
\text { Levels-g** } \\
(x / y / z)\end{array}$ & Comments \\
\hline 1 & $\begin{array}{l}1 \\
2 \\
3 \\
4\end{array}$ & $1.83 / 1.56 / 1.47 * \star \star *$ & Shake table limit \\
\hline 5 & $\begin{array}{l}1 \\
2 \\
3 \\
4 \\
5\end{array}$ & $1.65 / 1.5 / 1.5$ & $\begin{array}{l}\text { Clamps came loose. } \\
\text { Test stopped to tighten. } \\
\text { shake table limit }\end{array}$ \\
\hline 8 & $\begin{array}{l}1 \\
2 \\
3 \\
4\end{array}$ & $2.18 / 1.77 / 1.37$ & Shake table limit \\
\hline 11 & $\begin{array}{l}1 \\
2 \\
3 \\
4\end{array}$ & $2.16 / 1.59 / 1.63$ & Shake table limit \\
\hline
\end{tabular}

* The acceleration levels were generally increased for each run listed, so the runs imply cumulative severity.

* As measured on the shake table base mounting plate.

*** This run spectral data are plotted and available in the Appendices. 
Table 2

Seismic-Fragility Test Results

Multicell Tests

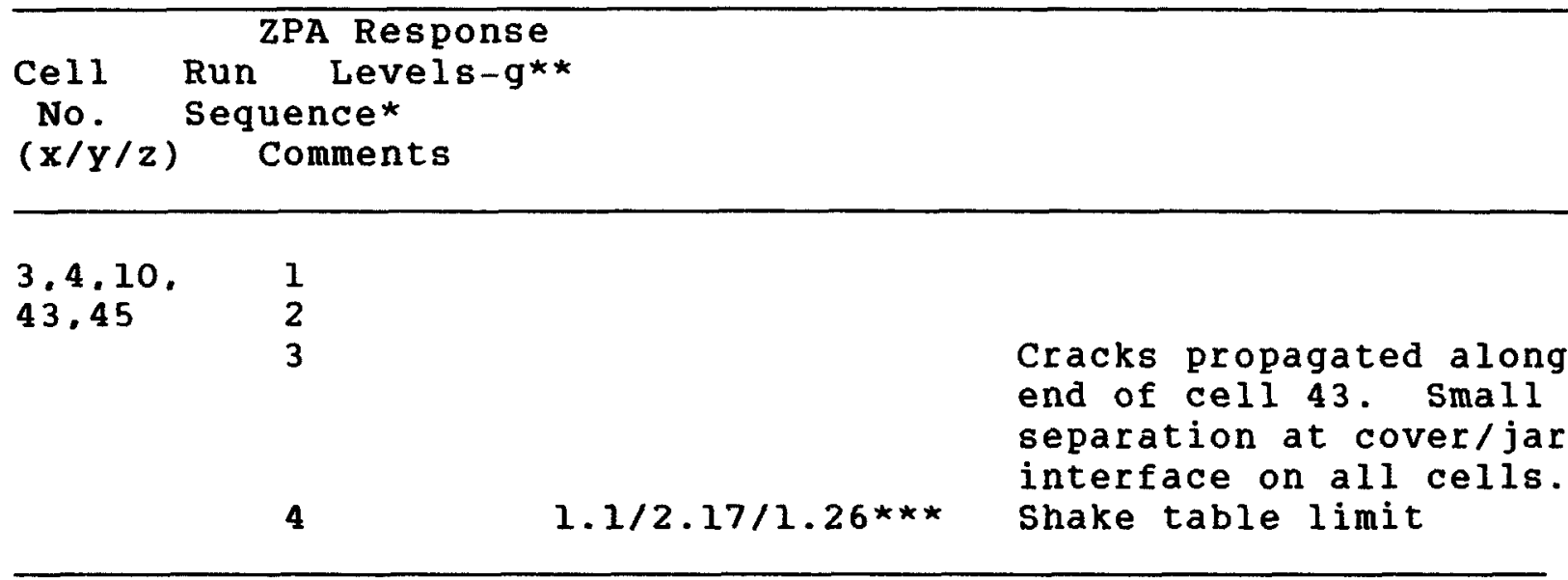

* The acceleration levels were generally increased for each run listed. so the runs imply cumulative severity.

** As measured on the shake table base mounting plate.

*** This run spectral data are plotted and available in the Appendices.

intended to investigate the failure modes (if any) of the internal components of the cells (e.g.. lead plates. lead hangers, and the like).

The five cells 1 isted in Table $2(3,4,10,43,45)$ were mounted in a multicell battery rack configuration based on the design of a "typical" seismically-qualified station battery rack. The purpose for this configuration was to check for (1) the influences of the rack-to-cells and cell-to-cell interactions on the cell responses and (2) the effect of typical rigid cell-to-cell electrical couplers between cell terminal posts. Overall. there seemed to be no particular differences in cell response as a result of testing in the single or multicell configurations.

\subsection{Postseismic Capacity Tests}

Following the seismic testing, five of the seismically tested cells were measured for their electrical discharge capacities. The results of those measurements are shown in Table 3 . In all 
Table 3

Cell Capacities Before and After Seismic Testing (Given in Percent of Rated Electrical Capacity)

\begin{tabular}{rrr}
\hline Cell & Before Testing & After Testing \\
\hline 3 & 84 & 13 \\
4 & 93 & 22 \\
10 & 96 & 22 \\
43 & 98 & 33 \\
45 & 82 & 30 \\
\hline
\end{tabular}

five cells the postseismic capacity was well below the accepted criterion of $80 \%$ even though all cells had a preseismic capacity of above $80 \%$.

\subsection{Posttest Disassembly and Evaluation}

Two of the tested cells ( 43 and 45 ) and one of the untested. low-capacity cells (15) were disassembled and inspected for internal damage. All components were found to be in poor condition. Corrosion products dislodged from the positive plate grids were found throughout the cell: e.g., in the sediment spaces. on top of the plates, loosely attached to the positive busses and terminal posts, and, in the seismically tested cells, lodged between positive plates and adjacent separators.

While no cracks were observed in post or bus material when the cells were opened, moderate hammer blows to the positive post broke the bus away from the post and showed areas where chemical attack had taken place. The chemical attack was most severe on the underside of the bus and decreased as the cross section was traversed from bottom to top. The positive plates were solid and not warped. but the active lead buttons near the extremities of the plates were clogged with active lead oxides. Other buttons in the centers of the plates were not so densely packed with oxides.

The negative plates were weak and brittle at their tops with a considerable amount of loose negative plate material. In addition most negative plates were severely erupted on both sides. Nonerupted areas corresponded to the positions of the plastic spacers. 
The extremely poor condition of both the negative and positive plates (e.g.. loose active material, clogged lead buttons, and corroded bus bars) undoubtedly resulted in the very low postseismic discharge capacities.

\subsection{CONCLUS IONS}

The tests and analyses can be summarized as follows (from Appendix A):

1. The twenty-seven year old Exide EMP-13 cells that were the subject of this study were in poor condition. They were all able to survive repeated strong shaking without sudden failures. but had all suffered from major losses in electrical capacity.

2. Internal components of the cells that were disassembled were in poor condition with extensive corrosion and embrittlement. The seismic testing caused corrosion products and active plate material to break away from the plates and lead to a loss in capacity.

3. There were no signs of damage to the jars during any of the tests. This includes tests with multi-cell racks.

Sandia staff concurs with the Ontario Hydro conclusions. Although these 27-year old cells were on-line as a part of a station battery to provide emergency power, the results of our testing indicate that the cells may not provide the minimum $80 \%$ discharge capacity after exposure to a seismic event.

\subsection{REFERENCES}

1. L. L. Bonzon and D. B. Hente. Test Series 1: SeismicFragility Tests of Naturally-Aged Class lE Gould NCX-2250 Battery Cells. SAND84-1737. NUREG/CR-3923, Sandia National Laboratories. Albuquerque. New Mexico, September 1984 .

2. LER 75-4, Turkey Point-4, "Cracked and Buckled Plates." Event date: October 13, 1974. Report date: October 23,1984 .

3. LER 77-55, Fitzpatrick-1, "Cracked Battery Cell Case," Event date: October 20, 1977, Report date: November 14. 1977.

4. LER 79-59, Fitzpatrick-1, "Cracked Battery Cell Case," Event date: September 4. 1979, Report date: October 2. 1979.

5. LER 81-42, Browns Ferry-1, "Cracked Cell," Event date: July 22. 1981. Report date: August 14. 1981. 
6. LER 82-7. Indian Point-2, "Battery Inoperable Due to Cracked Cel1." Event date: February 2, 1982, Report date: March 19. 1982 .

7. LER 82-16, Indian Point-2, "Battery Cell Cracks." Event date: April 23, 1982. Report date: May 24, 1982.

8. LER 82-6. Connecticut Yankee, "Cracked Emergency DC Battery Cells." Event date: September 19, 1982, Report date:

October 5, 1982 .

9. Eric W. Weiss, Possible Generic Battery Problem. Memo for R. William Mills, Chief, Events Analysis Branch, Office of Inspection and Enforcement. Nuclear Regulatory Commission. November 26,1982 .

10. IE Information Notice No. 83-11. Possible Seismic Vulnerability of old Lead storage Batteries, Office of Inspection and Enforcement, Nuclear Regulatory Commission, Washington. D.C.. March 14, 1983.

11. L. L. Bonzon, et al.. "An Overview of Equipment Survivability studies at Sandia National Laboratories (SNL)," SAND83-0759C. Proceedings of the ANS/ENS International Meeting on Light Water Reactor severe Accident Evaluation. Cambridge, Massachusetts, August 28 September 1. 1983 .

12. Ltr, L. L. Bonzon, SNL, to William Farmer, NRC, subject: "Test Plan to Evaluate Nuclear station Class IE Battery Aging Methodologies." dtd June 20, 1984

13. Ltr, L. L. Bonzon, SNL, to william Farmer, NRC, subject: "Test Plan for Seismic Testing of Naturally-Aged Nuclearstation stationary Battery Cells," dtd June 12, 1984. 


\section{APPENDIX A}

Executive Summary

Seismic Testing of Naturally Aged

Exide EMP-13 station Battery Cells
J. D. Tulk
D. A. Black
W. J. Janis
B. M. Kukreti

Ontario Hydro Reaserach Division 


\section{A. ontario hydro}

\section{EXECUTIVE SUMMARY}

SEISMIC TESTING OF NATURALLY AGED EXIDE EMP-13 STATION BATTERY CELLS

J.D. Tuik, Mechanical Research Department

D.A. Black, Mechanical Research Department

W.J. Janis, Chemical Research Department

B.M. Kukreti, Electrical Design Department

A sample of 27 year old lead acid storage batteries from the Shippingport Nuclear Power station (Shippingport, PA) were tested on a shaker table. The intensity of the shaker tests reached the full capacity of the table. There were no sudden changes in output voltage for any of the nine cells during the stimulated earthquakes. Following the tests, however, the capacity of the cells was found to be sharply reduced. A number of cells were disassembled and examined. Internal components were found to be in poor condition, with loss of negative plate material and generalized corrosion.

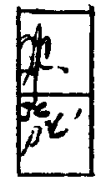

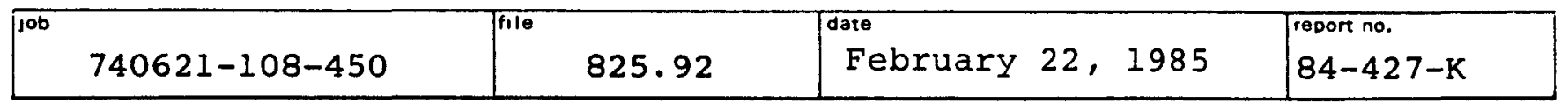


$\underline{\text { Page }}$

$\begin{array}{lll}1.0 & \text { INTRODUCTION } & 1\end{array}$

2.0 TEST METHODS AND RESULTS 2

2.1 Initial Inspection and Conditioning 2

2.2 Seismic Testing - Single Cells 2

2.3 Multi Cell Rack Test 4

2.4 Post Seismic Capacity Tests and Inspection 4

3.0 CONCLUSIONS 5 .

$\begin{array}{lll}4.0 & \text { ACKNOWLEDGEMENTS } & 6\end{array}$

$\begin{array}{ll}\text { REFERENCES } & 7\end{array}$

$\begin{array}{ll}\text { TABLES AND FIGURES } & 7\end{array}$ 
To Mr. B.A. Oliver

Manager

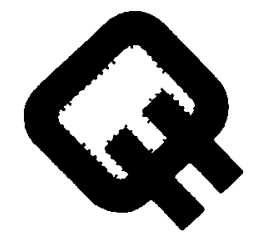

\title{
ontario hydro research division
}

Electrical Design Department

\author{
SEISMIC TESTING OF NATURALLY AGED EXIDE EMP-13 \\ STATION BATTERY CELLS
}

J.D. Tulk, Mechanical Research Department

D.A. Black, Mechanical Research Department

W.J. Janis, Chemical Research Department

B.M. Kukreti, Electrical Design Department

\subsection{INTRODUCTION}

The large lead-acid storage battery cells that are the subject of this report are used to provide dc power for nuclear power stations during and after an earthquake. It is well known that these cells deteriorate with age and it is normal practice to test them at regular intervals to ensure that they are capable of meeting a specified level of performance. What is not so well understood however, is the effect of age on the mechanical fragility of the cells and whether the cells would be capable of surviving seismic events at the operating basis earthquake (OBE) or safe shutdown earthquake (SSE) levels and to continue to meet the load profile required by the Class lE system. Because of the importance of storage batteries to the Class $1 \mathrm{E}$ system, the US Nuclear Regulatory Commission has requested Sandia National Laboratories (SNL) to evaluate the impact of aging and seismic exposure on battery capacity. Ontario Hydro has been subcontracted to carry out capacity and seismic shaker tests on naturally aged cells supplied by SNL from several Us nuclear power stations (SNL contract 47-4077). The orogram addresses possible variations between designs produced by different manufacturers.

This report describes the results of a series of experiments carried out at the Ontario Hydro Research Laboratories on a set of twenty-seven year old Exide EMP-13 cells from the Shippingport Nuclear Power Station (Shippingport, PA). During the shaker tests, no sudden loss of output voltage was recorded, even when the intensity of the shaking reached the limit of the table. However, following the tests, it was found that the capacity (time to discharge) of all of the cells had been reduced sharply. To determine the nature of the damage that was

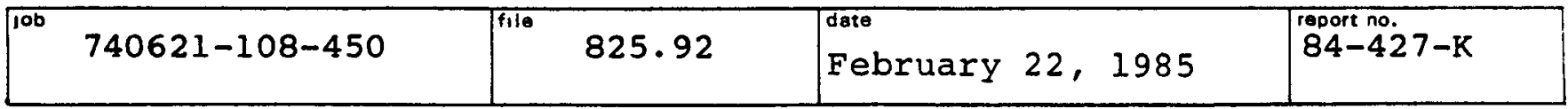


caused by the shaking, several cells were disassembled for inspection and metallurgical examination. The results indicate that this batch of cells was in generally poor condition with widespread corrosion and damage to the plates.

This report summarizes the test and results for this batch of cells. A more detailed discussion of the tests and results is contained in reports C84-121-P (battery condition and performance)/1/. B84-44-P (seismic test results, single cells)/2/ and 84-428-P (seismic tests, rack mounted cells) $/ 3 /$.

The tests described here were part of a larger program of testing of aged cells. Other cell types tested to date have included Gould FKR (Pickering NGS)/4,5,6/, Gould NCX2250 (Fitzpatrick NPS) $/ 7 /$, C\&D LCU-13 (North Anna NPS)/9/ and Exide FHC-19 (Calvert Cliffs NPS)/8/.

The Exide EMP-13 cells are of an obsolete type that is no longer being installed in nuclear power plants. They were however the oldest samples of station cells that could be obtained and it was for this reason that they were included in the program.

\subsection{TEST METHODS AND RESULTS \\ 2.1 Initial Inspection and Condition}

Twelve Exide EMP-13 cells were received from the Shippingport plant. There was no superficial damage, but the cells showed signs of aging, including swollen and warped plates and black precipitate on the bottom of the jars. Our experience with aged station cells suggests that the condition of these cells was consistent with their type and age. The cells were conditioned (charged and discharged several times to stabilize their internal chemical state) and tested for capacity. The electrical state of the cells prior to the seismic tests is summarized in Table 1 .

\subsection{Seismic Testing - Single Cells}

The shaker table and instrumentation used in these experiments is described in Reference 2. The table provides independent motion in three directions. The motion is based on a quasirandom signal, filtered to match the frequency content of a typical earthquake. The duration of each test was 30 seconds. The seismic test method is based on the recommendations of IEEE std 344-1975 and IEEE Std 501-1978.

For the first phase of the seismic testing, the cells were mounted individually on the shaker table in a stiff frame, designed to minimize relative motion between the cell jar and 
the table (see Figure 1). This series was intended to investigate possible failure modes of internal components. The rig was designed to minimize the danger of jar failure and acid spill. Accelerometers were mounted on the base of the frame and on the top of one of the posts of the cell.

Each cell was subjected to a series of tests at successively higher acceleration levels. The test sequence for each cell is shown in the test $\log$ given in Table 2. In this record, the acceleration level for each test is quoted in terms of the $\mathrm{ZPA}$ fitted IEEE 501 spectrum.

During the seismic tests, the cells were discharged against a resistive load at a one hour discharge rate. They were considered to have passed a seismic test if they remained above $1.75 \mathrm{~V}$ during and immediately after the test. The cells were shaken at progressively higher levels up to the machine limit. Each of the four cells that were tested in the single cell frame passed all of the tests. Table 2. provides a log of the test sequence, while Table 3 summarizes the results. Figures 3-14 show response spectra for the final test for each cell. There were no sudden drops in cell voltage during any of the shaker tests.

The seismic test results are presented in this report and in References 2 and 3 in terms of acceleration response spectra of the table motion. To provide a convenient means of comparing the acceleration levels encountered during various tests; each test spectrum is compared to a normalized spectrum defined in IEEE Std 501-1978 /10/. The shape of this spectrum is intended to reflect the frequency content of the "typical" seismic environment for electrical equipment. The intensity of the simulated seismic motion is expressed in terms of the ZPA (zero period acceleration).

\subsection{Multi-Cell Rack Test}

The single cell tests were designed to focus on failure modes of internal components. To examine the possible failure modes that would be encountered with normal in-plant mounting arrangements, a shaker test was carried out on a set of five cells mounted on a rack that resembled typical seismically qualified battery racks (see Figure 2). The test $\mathrm{log}$ and results are shown on Tables 2 and 3 . Figures $15-17$ show response spectra for the final test with the rack mounted cells. Again, no failures occurred. 
For practical reasons, the rack that was used for these tests held only five cells. Full scale racks in power stations are typically much longer. The present tests could be non-conservative since long strings of cells could, under violent shaking, impose large impact loads on cells at the end of the string. These tests provide no positive indication that this is a potential source of trouble. Nevertheless, we suggest that in severe seismic environments, it would be beneficial to separate cells into groups of three or so, with rigid partitions on the rack and flexible electrical connections between groups.

\subsection{Post Seismic Capacity Tests and Inspection}

Following the shaker table tests the cells were re-tested for electrical capacity. The results of these tests are shown on Table 1. There was considerable loss of discharge capacity for all cells and none were able to meet the acceptance criterion of $80 \%$ rated capacity.

Following these tests, four of the cells were disassembled and inspected. It was found that the internal components were in poor condition. On the negative plates, the grid material was cracked and broken near the top of the plates, while a significant proportion of the active material (sponge lead) had apparently been shaken out of the grids by the seismic tests. Plate surfaces were severely pitted and erupted, apparently a result of excessive gassing during service. On the positive plates, there were signs of extensive corrosion. During the shaker tests, a considerable amount of corrosion product had been shaken loose from the plates and in some instances, caused short-circuits between positive and negative plates. Negative bus material was corroded and brittle. Photographs illustrating the post-test condition of the cells can be found in Reference 1 .

\subsection{CONCLUSIONS}

1. The twenty-seven year old Exide EMPI3 cells that were the subject of this study were in poor condition. They were all able to survive repeated strong shaking without sudden failures, but had all suffered from major losses in electrical capacity. 
2. Internal components of the cells that were disassembled were in poor condition with extensive corrosion and embrittlement. The seismic testing caused corrosion products and active plate material to break away from the plates and lead to a loss in capacity.

3. There were no signs of damage to the jars during any of the tests. This includes tests with multi-cell racks. 


\subsection{ACKNOWLEDGEMENTS}

Test cells for this project were provided by Sandia National Laboratories. This support is gratefully acknowledged. Lloyd Bonzon and Done Hente of SNL are thanked for their large contribution to the project. Within ontario Hydro, contract co-ordination was handled by the Electrical Design Department. We are grateful to Colin Royce and Jerry schendel for their efforts. Much of the testing and analysis was carried out by Brian Aucoin of the Chemical Research Department and Gordon Paulson of the Mechanical Research Department. Their able work was essential to the successful outcome of the project.

Approved by:

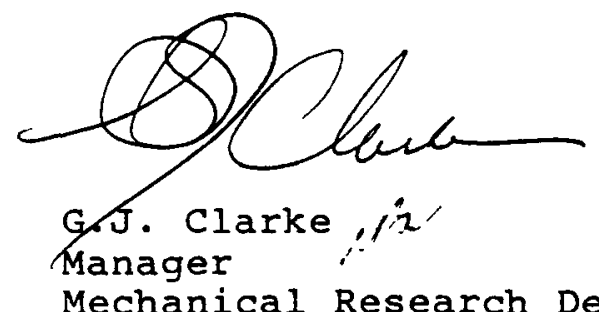

Mechanical Research Department

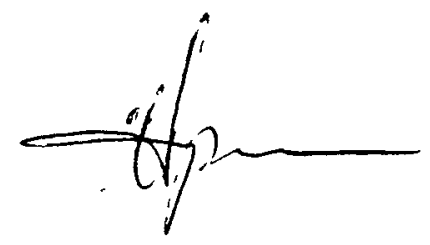

O.A. Kupcis

Manager

Chemical Research Department

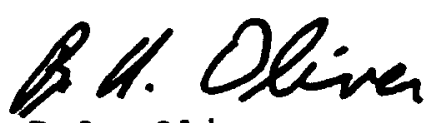

B.A. Oliver

Manager

Electrical Design Department

Design and Development Division

JDT /DAB/WJJ / BMK : LG
Submitted by:

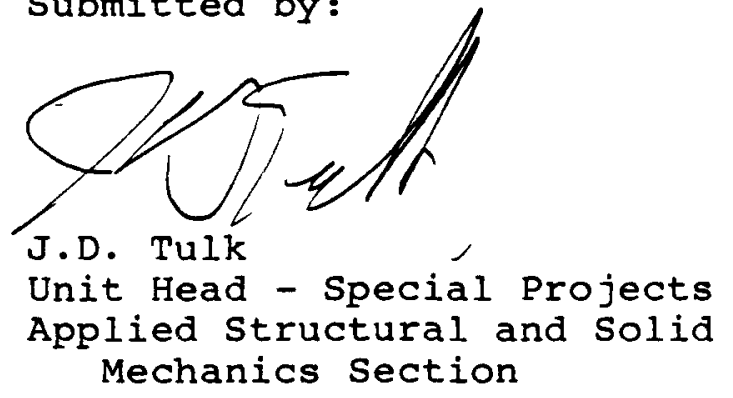

C. A. Blach

D.A. Black

Engineer

Lines, Materials \& Seismology

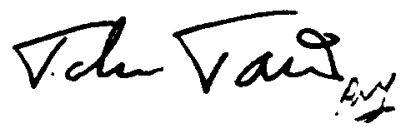

W.J. Janis

Chemist

Organic Section

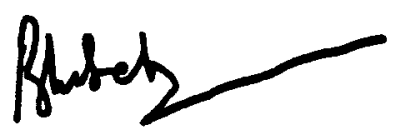

B.M. Kukreti

Engineer

Electrical Design Dept 


\section{REFERENCES}

1. W.J. Janis, "Seismic Testing of Shippingport Nuclear Power Station Batteries - Cell Inspection and Capacity Tests". Ontario Hydro Research Division Report C84-121-P.

2. D.A. Black and G.D. Paulsen, "Seismic Testing of Exide Aged Batteries". Ontario Hydro Research Division Report B84-44-P.

3. D.A. Black and G.D. Paulsen, "Seismic Testing of Exide Aged Batteries in a Rack". Ontario Hydro Research Division Report No 84-428-P.

4. W.J. Janis, "Seismic Testing of Aged Nuclear Generating Station Batteries - Cell Inspection and Capacity Tests". Ontario Hydro Research Division Report No C84-5-K.

5. G.D. Paulsen, "Seismic Qualification of Station Cells". Ontario Hydro Research Division. Report No B83-96-H.

6. D.A. Black and G.D. Paulsen. "Seismic Testing of Gould Cells Removed from Pickering GS in a Rack". Ontario Hydro Research Division Report No B84-38-P.

7. J.D. Tulk, D.A. Black, W.J. Janis and B.M. Kukreti, "Seismic Testing of Naturally Aged Station Battery Cells". NUREG/CR3923 SAND 84-13. (also issued as Ontario Hydro Research Division Report No B84-211-K).

8. J.D. Tulk, D.A. Black, W.J. Janis and B.M. Kukreti, "Seismic Testing of Naturally Aged C\&D LCU-13 Station Battery Cells". Ontario Hydro Research Division Report No $84-4250 \mathrm{~K}$.

9. J.D. Tulk, D.A. Black, W.J. Janis and B.M. Kukreti, "Seismic Testing of Naturally Aged Exide FHC-19 Station Battery Cells". Ontario Hydro Research Division Report No $84-426-K$.

10. IEEE Std 501-1978, "IEEE Standard, Seismic Testing of Relays". The Institute of Electrical and Electronics Engineers Inc., 1978. 
TABLE 1

CELL CAPACITIES BEFORE AND AFTER SEISMIC TESTING

\begin{tabular}{|c|c|c|c|c|c|c|}
\hline \multirow[b]{2}{*}{ Cell } & \multicolumn{3}{|c|}{$\begin{array}{l}\text { Time to } 1.75 \mathrm{VPC} \\
\text { at } 3 \mathrm{~h} \text { Rate (min) }\end{array}$} & \multicolumn{3}{|c|}{$\begin{array}{c}\text { Per Cent of Rated Capacity } \\
\text { at } 3 \mathrm{~h} \text { Rate }\end{array}$} \\
\hline & $\begin{array}{l}\text { Pre- } \\
\text { Seismic }\end{array}$ & $\begin{array}{l}\text { Post- } \\
\text { Seismic* }\end{array}$ & $\begin{array}{c}\text { Post- } \\
\text { Seismic } \\
\text { Plus } \\
\text { Seismic** }\end{array}$ & $\begin{array}{l}\text { Pre- } \\
\text { Seismic }\end{array}$ & $\begin{array}{l}\text { Post- } \\
\text { Seismic* }\end{array}$ & $\begin{array}{c}\text { Post- } \\
\text { Seismic } \\
\text { Plus } \\
\text { Seismic** }\end{array}$ \\
\hline $\begin{array}{r}3 \\
4 \\
10 \\
43 \\
45\end{array}$ & $\begin{array}{l}151 \\
167 \\
172 \\
177 \\
147\end{array}$ & $\begin{array}{l}10 \\
25 \\
25 \\
45 \\
40\end{array}$ & $\begin{array}{l}24 \\
39 \\
39 \\
59 \\
54\end{array}$ & $\begin{array}{l}84 \\
93 \\
96 \\
98 \\
82\end{array}$ & $\begin{array}{r}4 \\
14 \\
14 \\
25 \\
22\end{array}$ & $\begin{array}{l}13 \\
22 \\
22 \\
33 \\
30\end{array}$ \\
\hline Avg & 163 & 29 & 43 & 91 & 16 & 24 \\
\hline
\end{tabular}

* Cells not recharged following seismic testing.

* * Capacity during seismic test at $1 \mathrm{~h}$ rate converted to $3 \mathrm{~h}$ capacity and added to post-seismic capacity, as discussed in Appendix 3 . 
TABLE 2

TEST LOG OF SEI SMIC TESTS ON EXIDE CELLS

\begin{tabular}{|c|c|c|c|c|}
\hline $\begin{array}{c}\text { Test } \\
\text { No }\end{array}$ & $\begin{array}{l}\text { Run } \\
\text { No }\end{array}$ & $\begin{array}{c}\mathrm{Ce} 11 \\
\text { No }\end{array}$ & $\begin{array}{l}\text { Approx ZPA } \\
\text { Level (g) } \\
\text { IEEE 501 }\end{array}$ & Comments \\
\hline 1 & $\begin{array}{l}1 \\
2 \\
3 \\
4\end{array}$ & $\begin{array}{l}8 \\
8 \\
8 \\
8\end{array}$ & $\begin{array}{l}0.8 \\
1.0 \\
1.3 \\
1.7\end{array}$ & Shaker limit \\
\hline 2 & $\begin{array}{l}1 \\
2 \\
3 \\
4\end{array}$ & $\begin{array}{l}1 \\
1 \\
1 \\
1\end{array}$ & $\begin{array}{l}0.8 \\
1.0 \\
1.3 \\
1.7\end{array}$ & Shaker limit \\
\hline 3 & $\begin{array}{l}1 \\
2 \\
3 \\
4 \\
5\end{array}$ & $\begin{array}{l}5 \\
5 \\
5 \\
5 \\
5\end{array}$ & $\begin{array}{l}0.8 \\
1 \cdot 0 \\
1 \cdot 0 \\
1 \cdot 3 \\
1.7\end{array}$ & $\begin{array}{l}\text { Jar clamps came loose. Test stopped. } \\
\text { Shaker limit. }\end{array}$ \\
\hline 4 & $\begin{array}{l}1 \\
2 \\
3 \\
4\end{array}$ & $\begin{array}{l}11 \\
11 \\
11 \\
11\end{array}$ & $\begin{array}{l}0.8 \\
1.0 \\
1.3 \\
1.7\end{array}$ & Shaker limit. \\
\hline \multicolumn{5}{|c|}{ Multi-Cell Rack Test (July 26/84) Cells $43,10,4,3,45$} \\
\hline & $\begin{array}{l}1 \\
2 \\
3 \\
4\end{array}$ & & $\begin{array}{l}0.8 \\
1.0 \\
1.3 \\
1.5\end{array}$ & No failures. \\
\hline
\end{tabular}


TABLE 3

MINIMUM ZPA VALUES(g)

\begin{tabular}{|c|c|c|c|}
\hline Cell & Location & Direction & ZPA \\
\hline 8 & $\begin{array}{l}\text { base } \\
\text { base } \\
\text { base } \\
\text { terminal } \\
\text { terminal } \\
\text { terminal }\end{array}$ & $\begin{array}{l}X \\
Y \\
Z \\
X \\
Y \\
Z\end{array}$ & $\begin{array}{l}2.18 \\
1.77 \\
1.37 \\
2.00 \\
2.24 \\
1.47\end{array}$ \\
\hline 1 & $\begin{array}{l}\text { base } \\
\text { base } \\
\text { base } \\
\text { terminal } \\
\text { terminal } \\
\text { terminal }\end{array}$ & $\begin{array}{l}X \\
Y \\
Z \\
X \\
Y \\
Z\end{array}$ & $\begin{array}{l}1.83 \\
1.56 \\
1.47 \\
1.84 \\
2.00 \\
1.63\end{array}$ \\
\hline 5 & $\begin{array}{l}\text { base } \\
\text { base } \\
\text { base } \\
\text { terminal } \\
\text { terminal } \\
\text { terminal }\end{array}$ & $\begin{array}{l}X \\
Y \\
Z \\
X \\
Y \\
Z\end{array}$ & $\begin{array}{l}1.65 \\
1.50 \\
1.50 \\
1.65 \\
1.54 \\
2.61\end{array}$ \\
\hline 11 & $\begin{array}{l}\text { base } \\
\text { base } \\
\text { base } \\
\text { terminal } \\
\text { terminal } \\
\text { terminal }\end{array}$ & $\begin{array}{l}X \\
Y \\
Z \\
X \\
Y \\
Z\end{array}$ & $\begin{array}{l}2.16 \\
1.59 \\
1.63 \\
1.85 \\
2.00 \\
1.56\end{array}$ \\
\hline $\begin{array}{l}\text { 43, } 10,4,3,45 \\
\text { (rack test) }\end{array}$ & $\begin{array}{l}\text { base } \\
\text { base } \\
\text { base } \\
\text { terminal } \\
\text { terminal } \\
\text { terminal }\end{array}$ & $\begin{array}{l}X \\
Y \\
Z \\
X \\
Y \\
Z\end{array}$ & $\begin{array}{l}1.1 \\
2.17 \\
1.26 \\
1.31 \\
0.8 \text { * } \\
1.22\end{array}$ \\
\hline
\end{tabular}

* accelerometer malfunction 

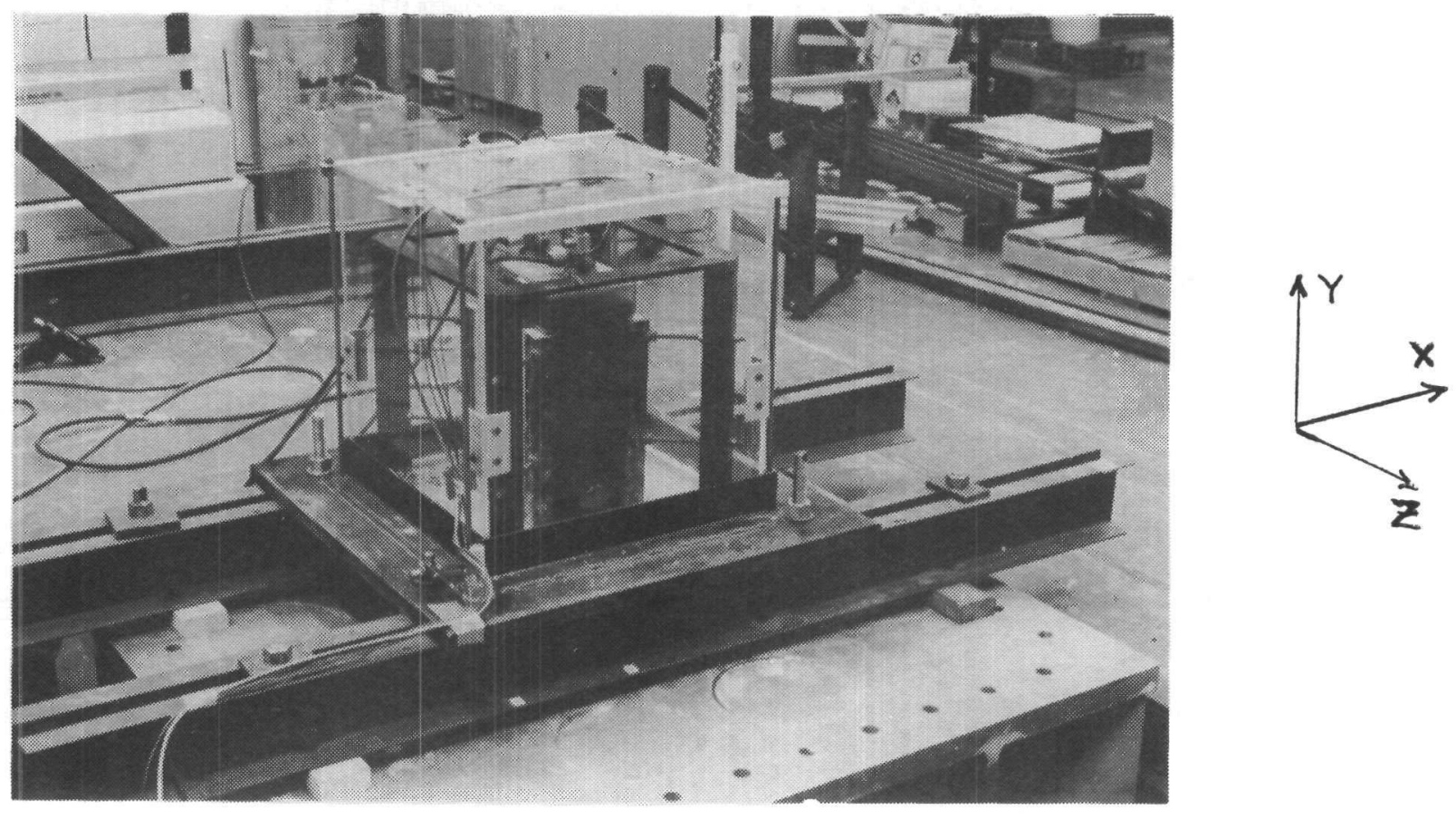

FIGURE 1

MOUNTING ARRANGEMENT FOR SINGLE CELL TESTS

THE CELL IS CLAMPED IN PLACE BY THREADED RODS.

ACCELEROMETERS ARE MOUNTED ON THE BASE AND ON A CELL TERMINAL POST. ACCELEROMETER DIRECTIONS ARE AS INDICATED. 


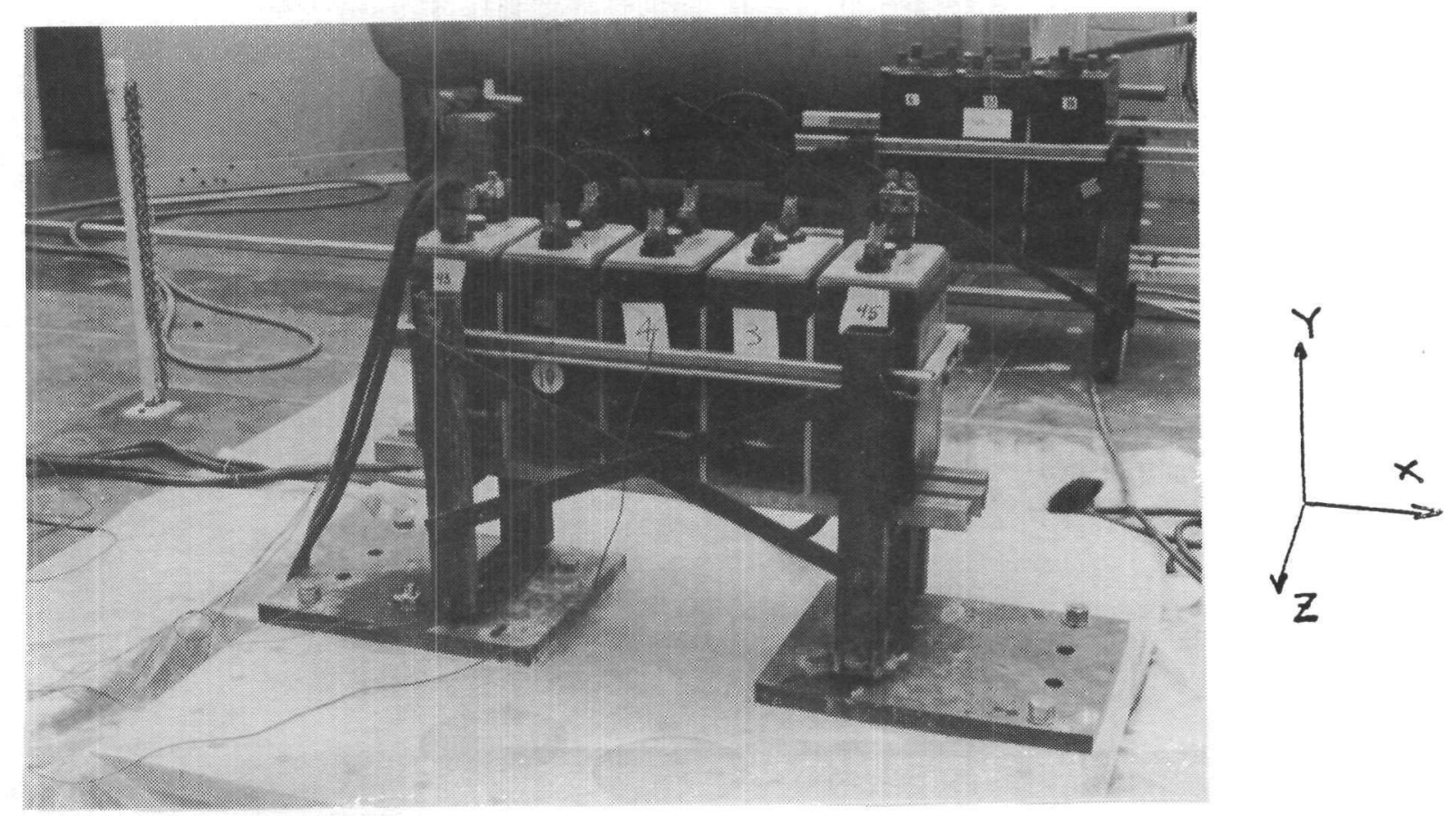

FIGURE 2

MOUNTING ARRANGEMENT FOR BATTERY RACK TESTS

ACCELEROMETERS ARE MOUNTED ON THE BASE AND ON A CELL TERMINAL POST. ACCELEROMETER DIRECTIONS ARE AS INDICATED. 


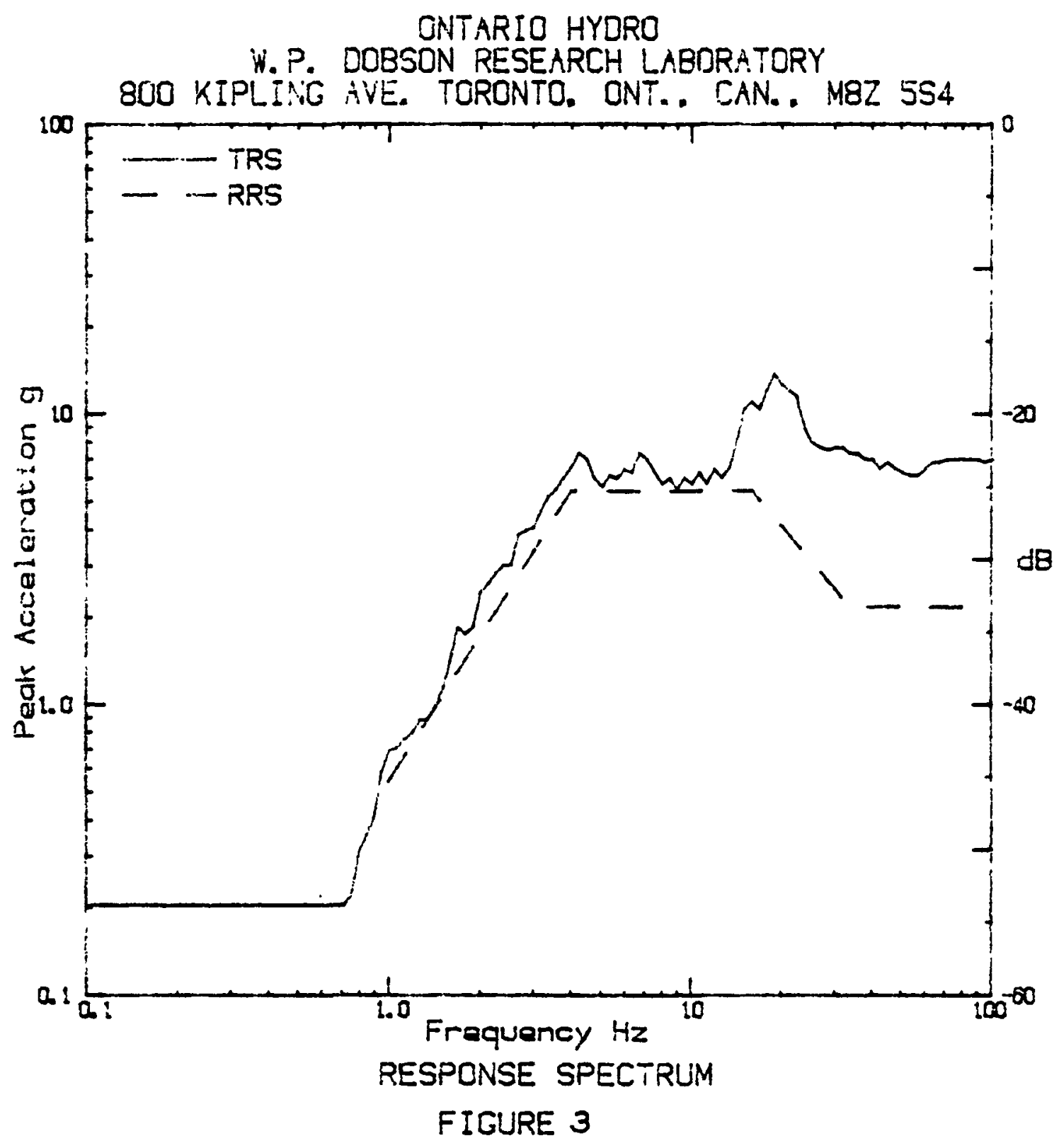

TEST ITEM

Station cella Exida Modal EMP 13. Sarial 9.

PARTICLLARS

March i4,84. Time 12:28, Temp('O) 23. Humidity(5) 39.

Prose (frajioo. 2. Graph $51: 0$

SPECIFICATIONS

Spacs IEEE SOl. Conditions span 6.8, voltaga \& currant monitorad

ANALYSIS

Type Heximax. Damping (\$) 5. B. W. = i/l2 Dctoves, Axis X

Shakar $\pm-i-$ txial. $2 P X=$ ?. iBg

ACCELERDMETER

Wilcoxon. Serial 575\%. Range dB58. Location bose-mounting jig.

Ti 702. Channal : 


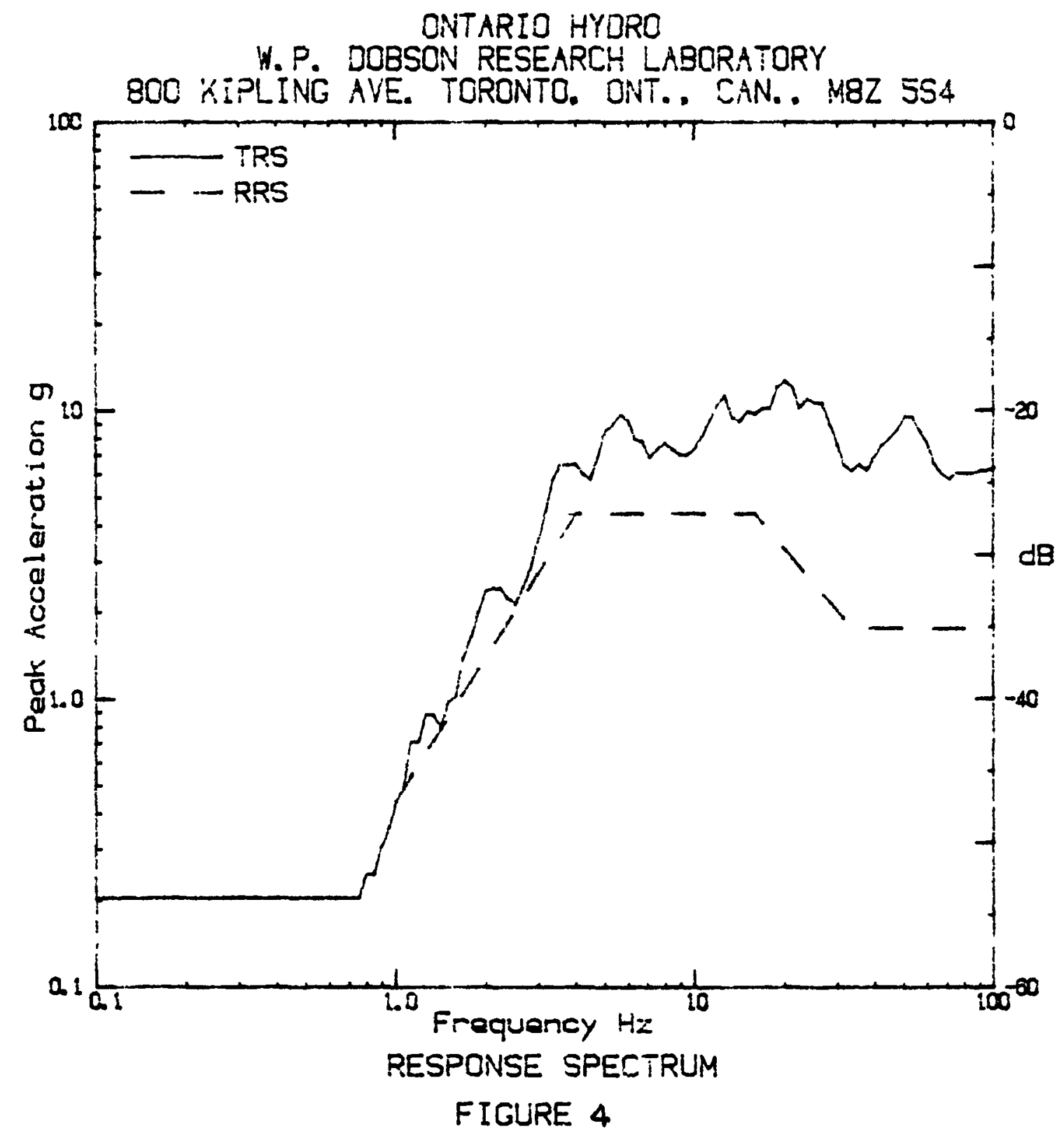

TEST ITEM

Station celis. Exida. Modal EMP 13. Seria! 8.

PARTICU!_ARS

March 14/84. Time ila 28. Tamp('C) 23. Humidity(x) 39.

Praes (kPa) 100. 2. Graph 5111

SPECIFICATIONS

Spece IEEE 50i. Conditions span 6.8. voltage 8 currant monitored

ANALYSIS

Type Maximax, Damping (a) 5, 9. Shaker tri-axial. ZPA=1.77@

ACCELEROMETER

Wilcoxon. Sarial 5761. Range d858. Locction base-molinting jig.
TT 702. Channel 2 


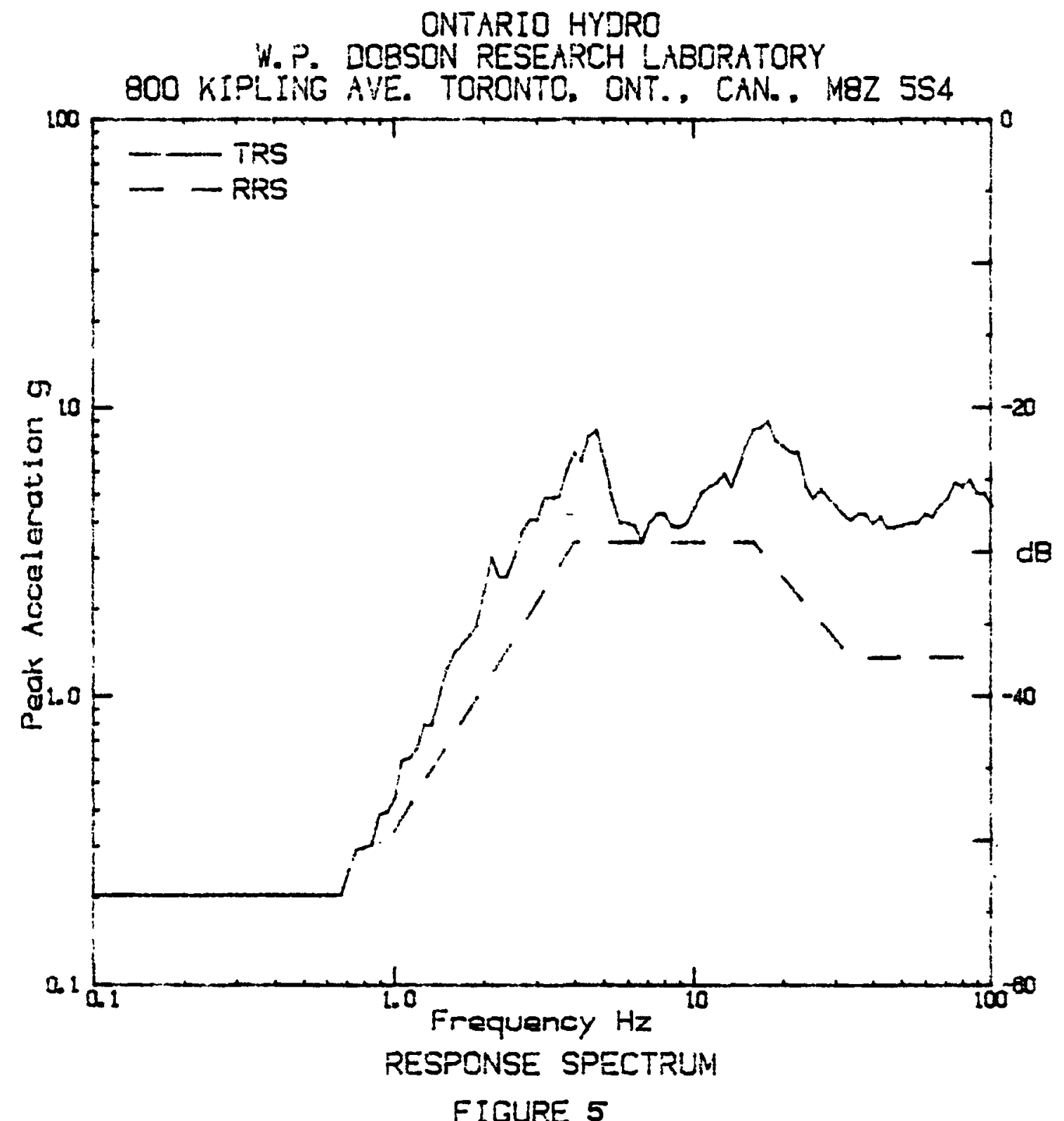

TEST ITEM

Station cails, Exide. Model EMP 13. Serial 8.

PART ICULARS

March 14/84, Time 11s 29, Tamp ('C) 23. Humidity(x) 39.

Preso (kPa) ioc. 2. Greph 5112

SPECIFICATIONS

Specs IEEE 50\%, Conditions span 6. 8. voitage \& currant monitored

ANALYSIS

Type Yoximax, Damping (Z) S, B. $\mathrm{K}_{0}=\mathrm{i} / 12$ Dctaves, Axis Z, Shaker tri-axial. ZPA=1. $37 \mathrm{~g}$

ACCELEROMETER

Wicoxon. Serieil 5901. Range deSa, Location bcse-mounting jig. TT 702. Channal 3 


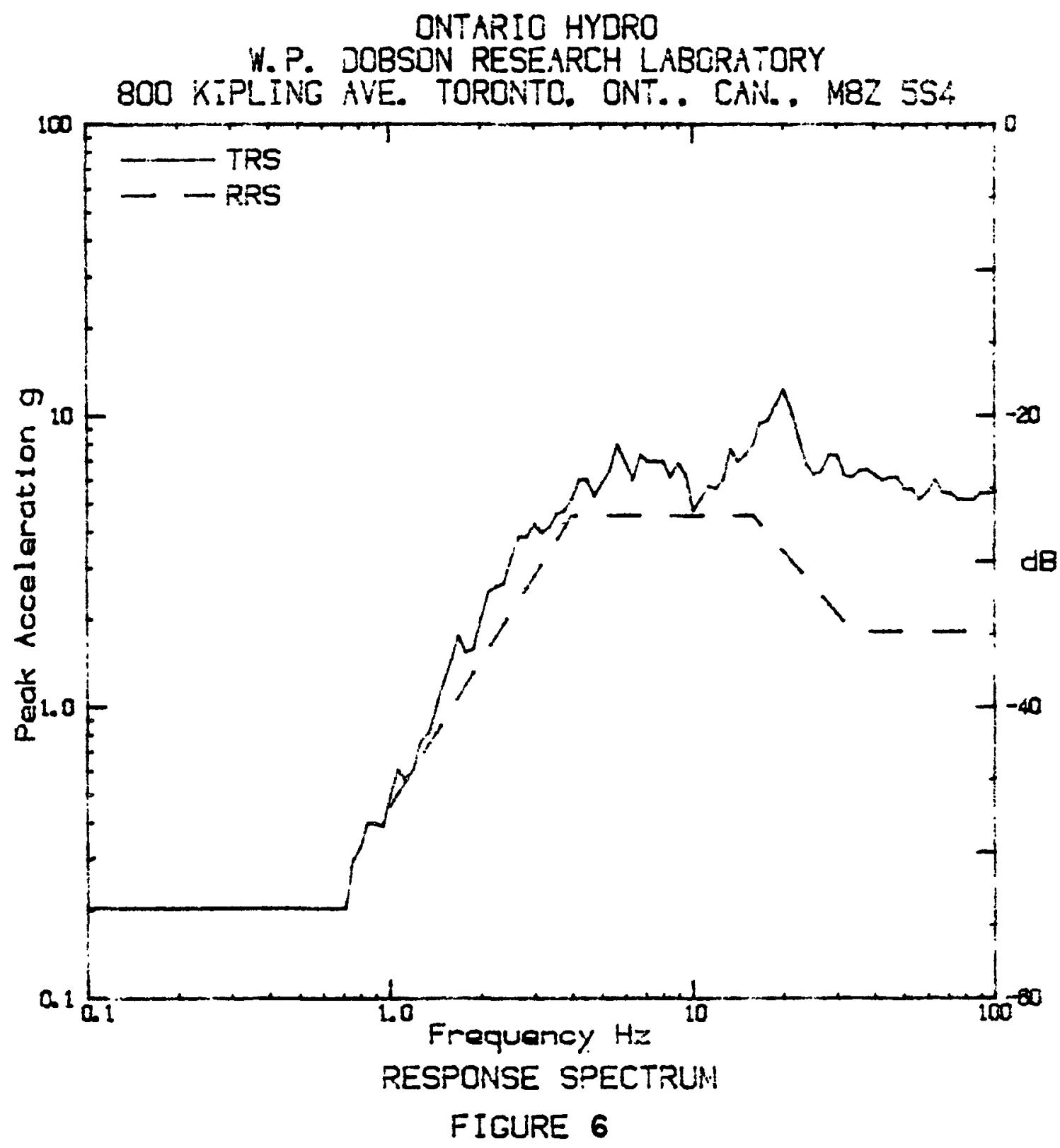

TEST ITEM

Station calis. Exide. Modal EMP 13. Saricl 1

PARTICULARS

Warch 14,'94, Time 1:45. Temp('C) 23, Humidity (o) 39.

Prass (kPO) 100.2. Graph $5 i 16$

SPECIFICATIONS

Specs IEEE 501 . Conditions span 6.8. voltage \& aurrant monitored

ANALYSIS

Type Maximax, Demping (x) 5, 8. $w_{0}=1 / 12$ Getaves, Axis $x$

Shaker tri-cxial. $Z P X=1.83 g$

ACCELEROMETER

Wilcoxon. Sarial 5757. Range dB58, Location bcse-mounting jig. $\pi$ 710, Channel 1 


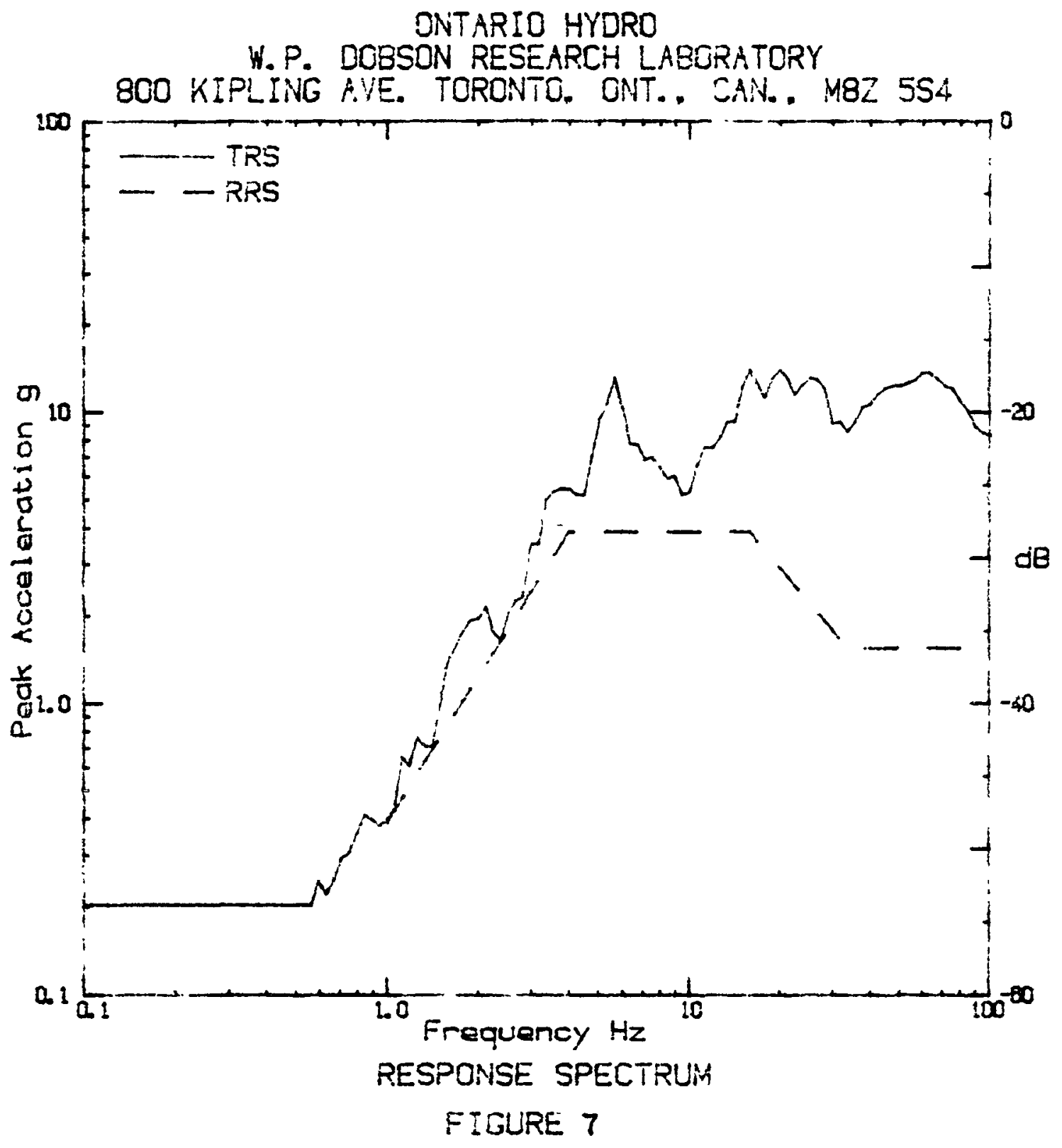

TEST ITEM

Stotion calls, Exida Modal EMP 13. Serial 1

PARTICULARS

March 14,84, Time 1: 45, Temp ('C) 23. Humidity $(0) 39$.

Praes (KPa) 100 2. Graph 5117

SPECIFICATIONS

Specs IEEE 501. Conditions span 6.8, voltage \& current monitored

ANALYSIS

Type Maximex. Damping (\#5. 6. $\%=1 / 12$ Dataves, Axis $Y_{0}$ Shaker tri-oxiol. $2 P A=1.56 \mathrm{~g}$

ACCELEROMETER

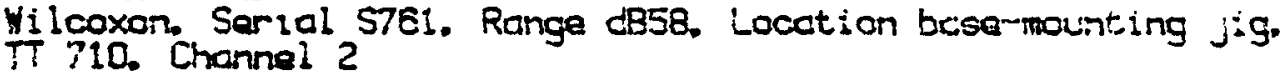




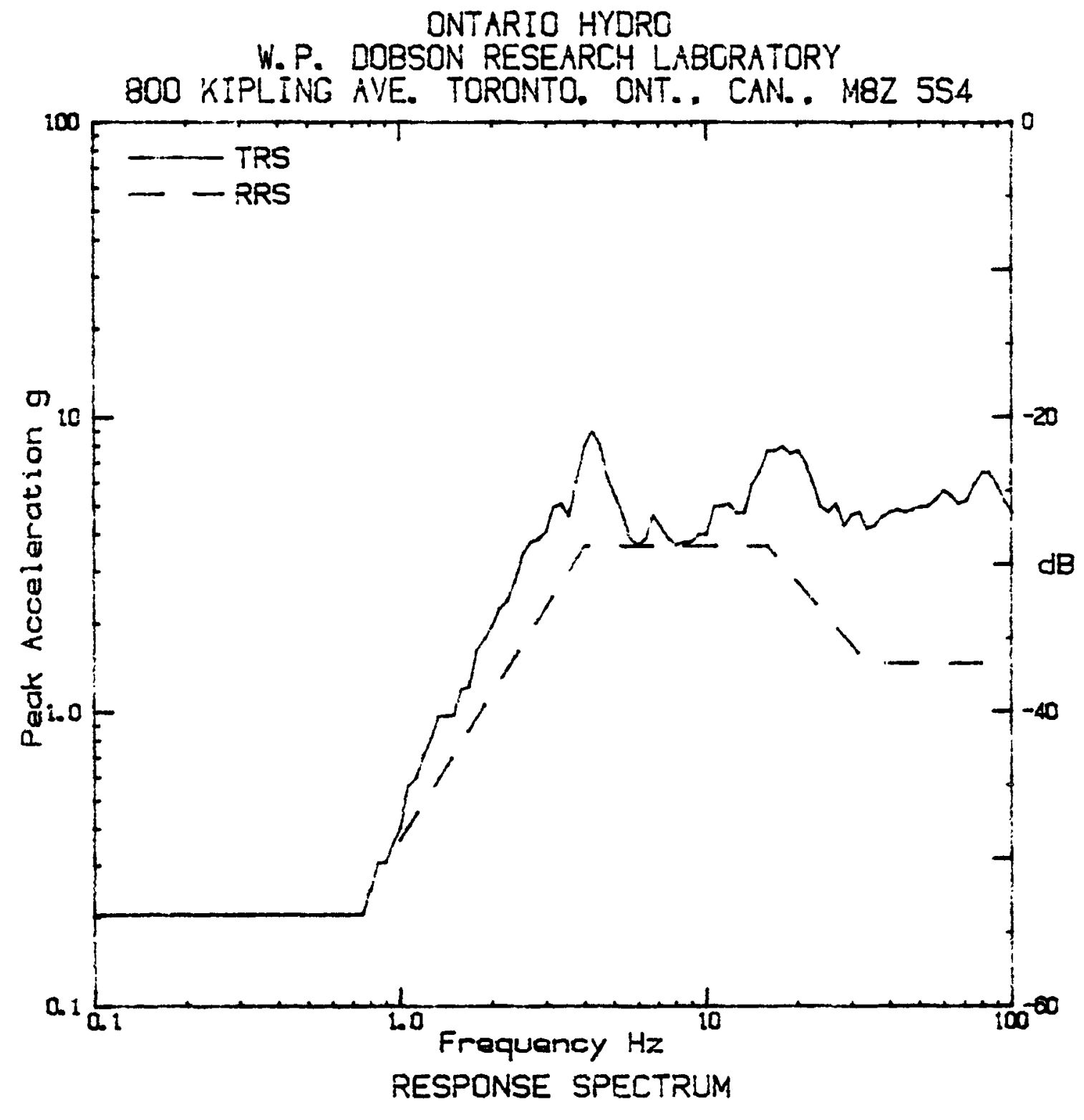

FIGURE 8

TEST ITEM

Station calls, Exida Madal EMP 13. Serial 1

PARTICULARS

March 14:84, Time 1: 45. Temp('C) 23. Humidity(s) 39.

Prass (kPa) 100 2. Graph 5118

SPECIFICATIONS

Specs IEEE 501. Conditions span 6.8. voltage 8 currant manitorad

ANALYSIS

Type Maximcx, Damping (⿻) 5. B. $W_{0}=1 / 12$ Dctovee. Axis Z. Shaker tri-oxial. ZPR $=1.47 g$

ACCELEROMETER

Wilcoxon. Sorial 5901. Range dB58, Location base-mounting jig. TT 710. Channel 3 


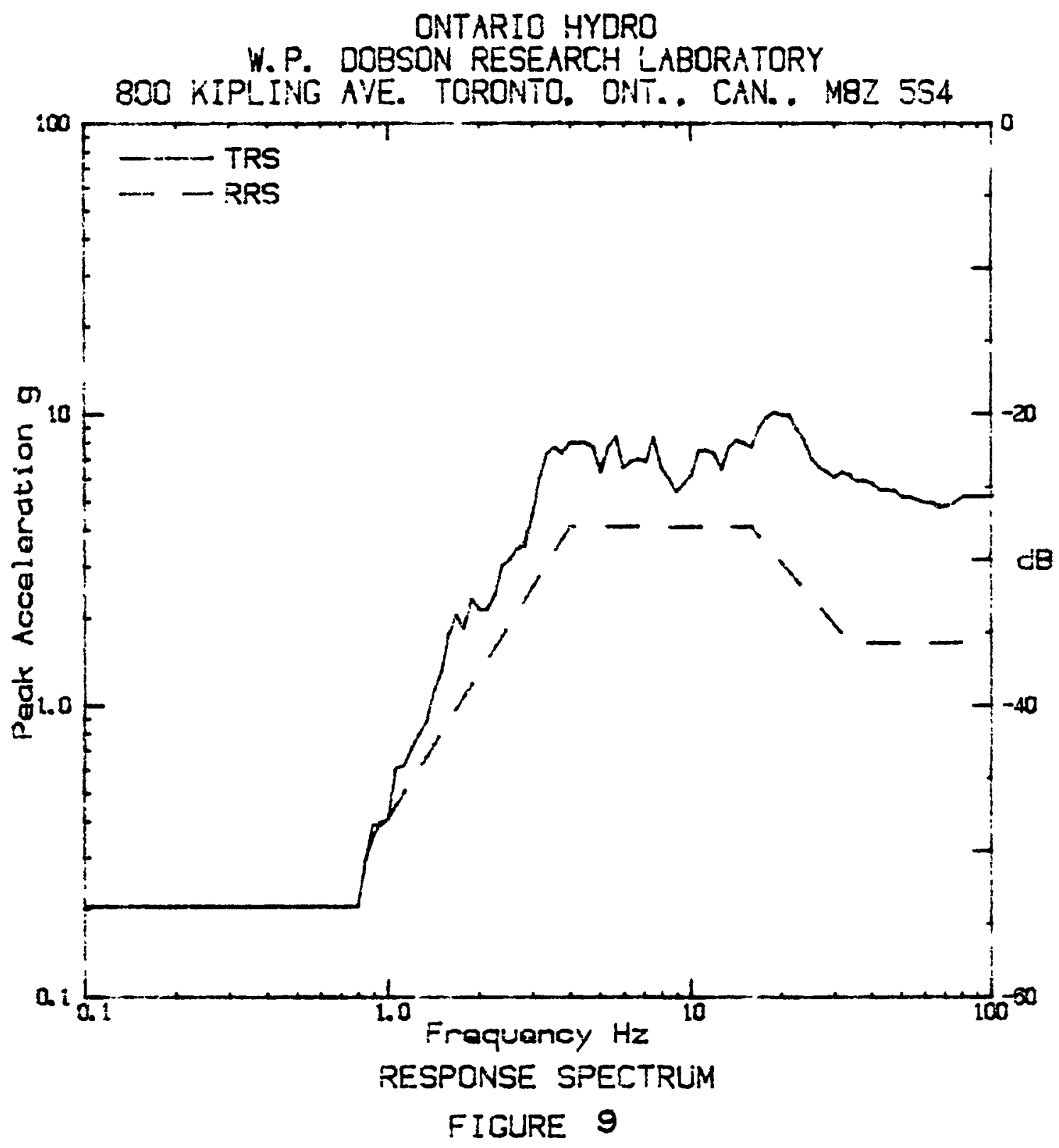

TEST ITEM

Station cells. Exide. Hadai EMP 13. Sorial 5.

PARTICLULARS

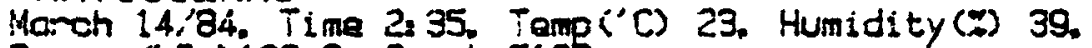

Prass (kPa) 1002 . Graph 5122

SPECIFICATIONS

Spacs IEEE 501. Conditions span 6.8, voltoge 3 cumpant monitored

ANALYSIS

Type Maximax. Damping (\%) 5. B. W. = 1/12 Detaves, Axis X. Shater t-i-cxial. 2PX=1. $55 \mathrm{~g}$

ACCELEROMETER

Wilcoxon. Seriai S757. Ronge d858. Locetion base-mounting jig: TT 720. Channei i 


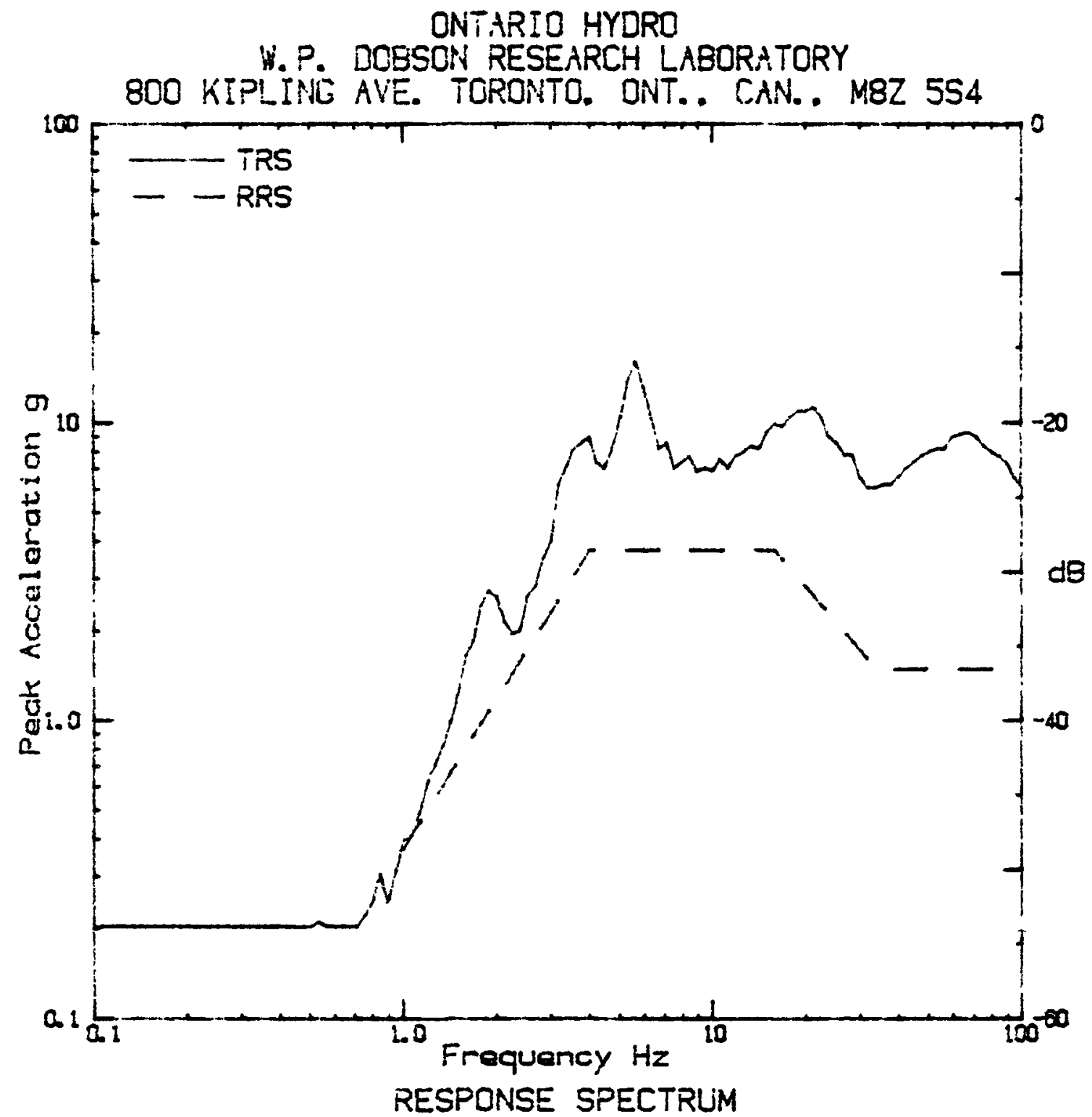

FIGURE 10

TEST ITEM

Stotion ceils, Exide. Modal EMP 13, Sarial 5.

PARTICULARS

March 14;84, Time 2335. Temo('C) 23. Humidity(z) 39.

Prass (KPa):00. 2. Graph 5123

SPECIFICATIONS

Specs IEEE 50\%. Conditions span 8.8. voltage \& CLrrent monitored

ANALYYSIS

Type Meximox. Damping (D)5. B. $W_{0}=1 / 12$ Detaves. Axis $Y_{0}$ Shaker tri-axial. $2 p h=1.5 g$

ACCELEROMETER

Wileoxion. Sarial S76!. Range d858. Locotion base-mounting jig.

IT 720. Channel 2 


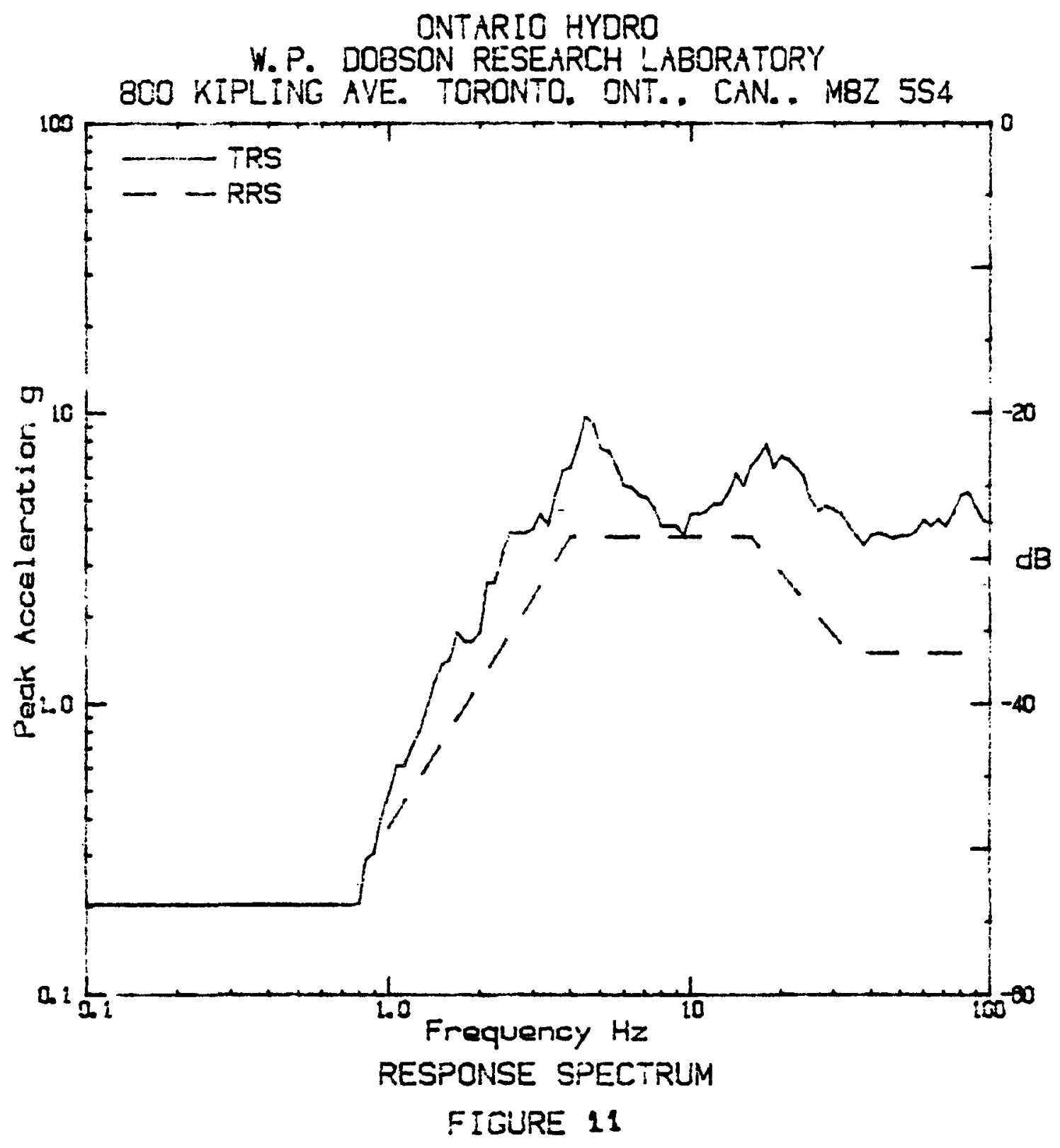

TEST ITEM

Station colls. Exide Hodal EMP 13. Seriai 5.

PARTICULARS

March 14/84. Time 2: 35. Temp('C) 23. Humidity $(\Leftrightarrow) 39$.

Press (KPa) 100. 2. Graph 5124

SPECIFICATIONS

Specs IEEE 501. Conditions span 3.8. voltage \& eurrant monitored

ANALYSIS

Type Moximax. Domping (\%) 5. B. Wo $=1 / 12$ Gctoves, Axis Z.

Shakar tri- $=x i c l .2 \mathrm{PP}=1.5 \mathrm{~g}$

ACCELEROMETER

Wilcoxen Sariai S90l. Range d858. Lecction base-mounting jis. 


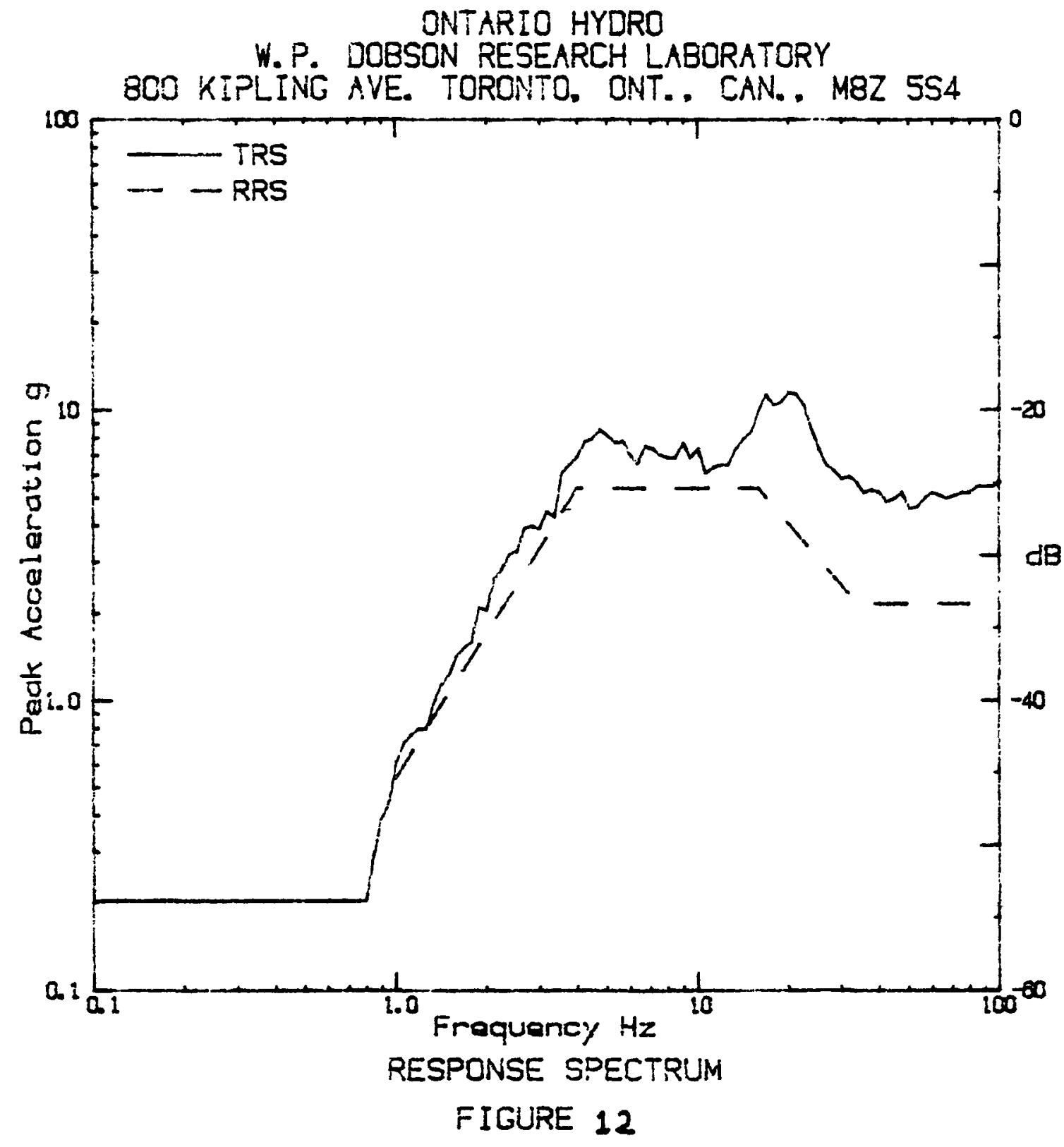

TEST ITEM

Station cells. Exida. Modal EMP i3. Seriel 11.

PAFTICULARS

March i4/84. Time 3800 jamp ('C) 23. Humidity (\%) 39.

Press (kPa) 100. Z. Graph 5128

SPECIFICATIONS

Specs IEEE 501. Conditions span 6.8. voltoge \& currant monitored

ANALYSIS

Type Maximax. Damping (む) 5, B. $K_{0}=1 / 12$ Dctaves. Axis $X_{0}$ Shaker tri-axial. ZPR $=2.169$

ACCEL_ERDMETER

Wilcoxon. Sariai S757. Range dB58. Location bose-mounting jig. iT 730. Channel ? 


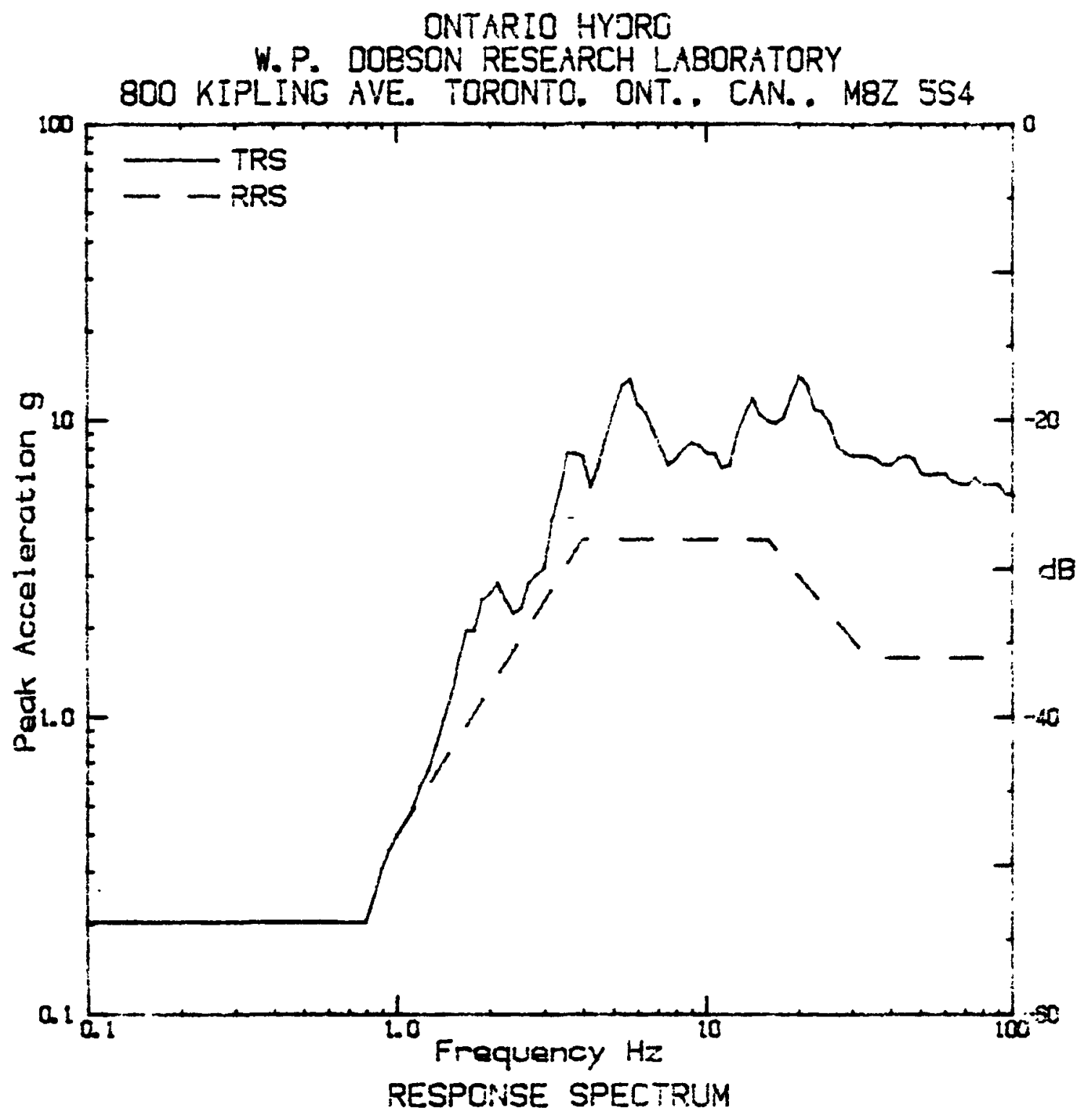

FIGURE 13

\section{TEST ITEM}

Station calls. Exida Model EMP 13. Seriai il.

\section{PARTICULARS}

Marah 14/84, Time 33 CO. Temp ('C) 23, Humidisy (') 39.

Prass (KPaj ica 2. Graph 5129

SPECIFICATIONS

Space IEEE 501. Conditions span 0.8. voltage \& aurrent monttored

APALYSIS

Type Maximax, Demping $\cos 5$, B. $W_{0}=1 / 12$ Detaves, Axis $Y$.

Shaker to $i-a x i a l$. $Z P X=1.59 g$

ACCELEROMETER

Wilcoxon. Serial 5761. Range de5e. Locotion base-mounting jig. TT 730. Channei 2 


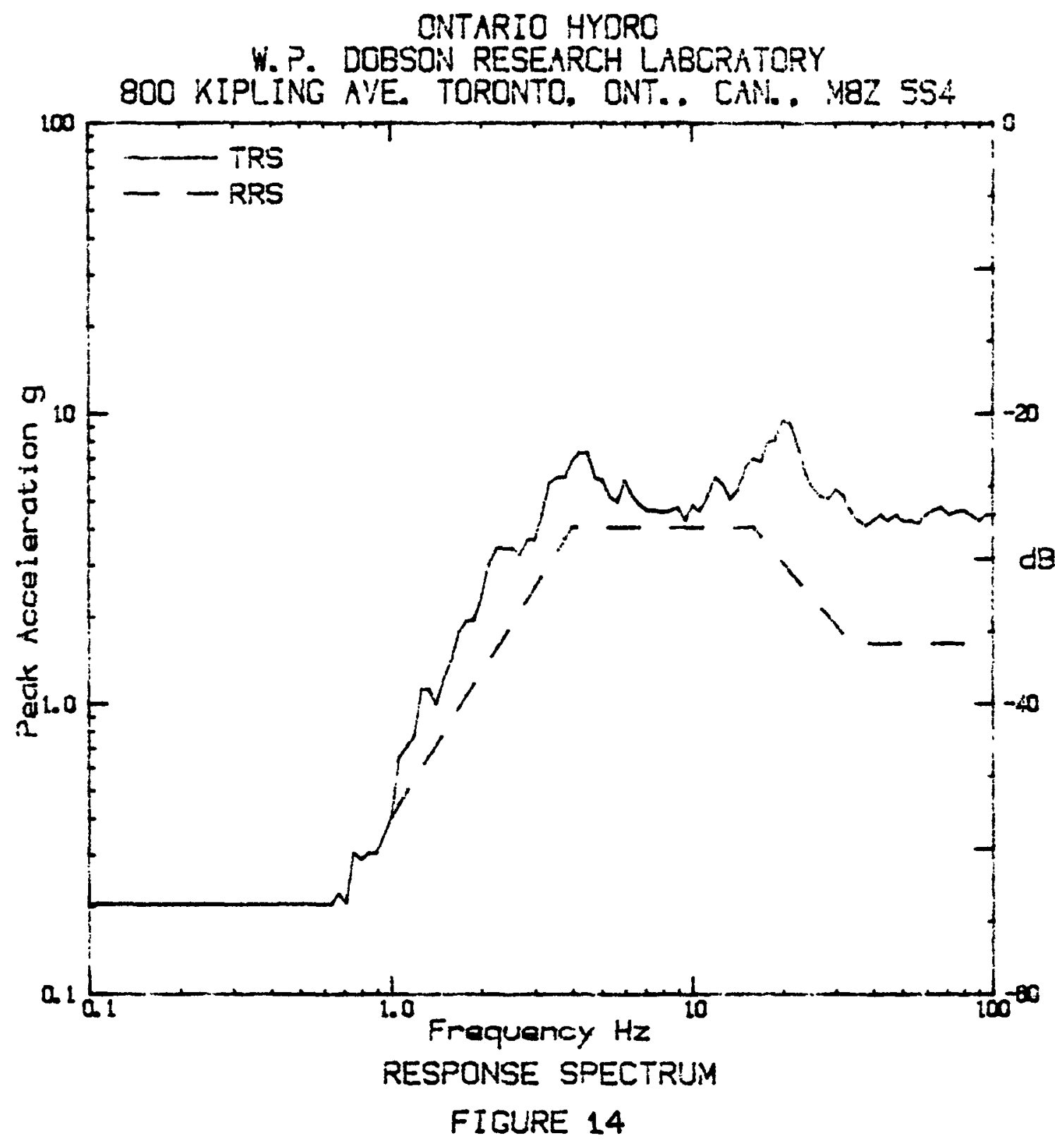

TEST ITEM

Stotion callo. Exida Madal EMP 13. Sartal 11.

PARTICLLARS

March 14/84. Time 3a00. Tamp $\left\langle{ }^{\prime} C\right)$ 23. Humidity 00 39.

Prese (KPo) iod. 2. Graph 5130

SPECIFICATIONS

Specs IEEE 501. Conditions span 8.8. voltoge a current monitorad

ANALYSIS

Type Haximax, Damping

Shoker tri-cixial. $Z P_{n=1.83 g}$

ACCELERDMETER

Wilcoxono Seriel 5901 . Range dB58. Location bssa-mounting jig. T. 730 . Channal 3 


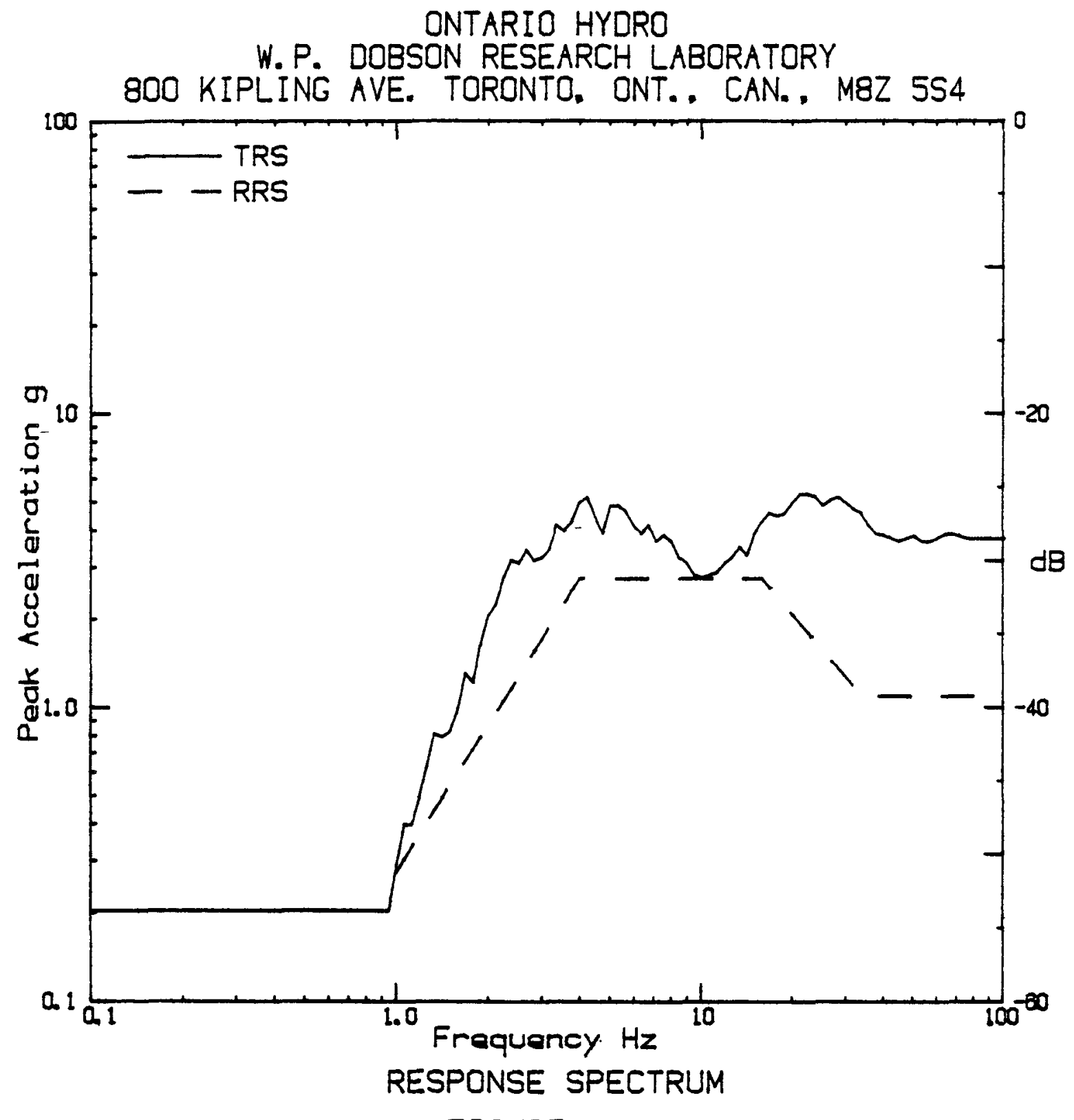

FIGURE 15

TEST ITEM

Station Cells \& Rack. Exida, Modal EMP-13, Sarial 43, 10, 4, 3, 45

PARTICULARS

July 26/84, Time 3z08. Temp ('C) 23. Humidity ( $(x)$ 55. Press (kPa) 100. Graph 5260

SPECIFICATIONS

Specs IEEE 501. Conditions oparating i 1 hour rate, span 7

ANALYSIS

Type Maximax. Damping (z) 5, B. W. $=1 / 12$ Octoves, Axis $X_{0}$ Shaker tri-axial. $Z P X=1.1 \mathrm{~g}$

ACCELEROMETER

Wilcoxon, Serial S297. Range dB49. Location base-mounting plate. Channel 1 


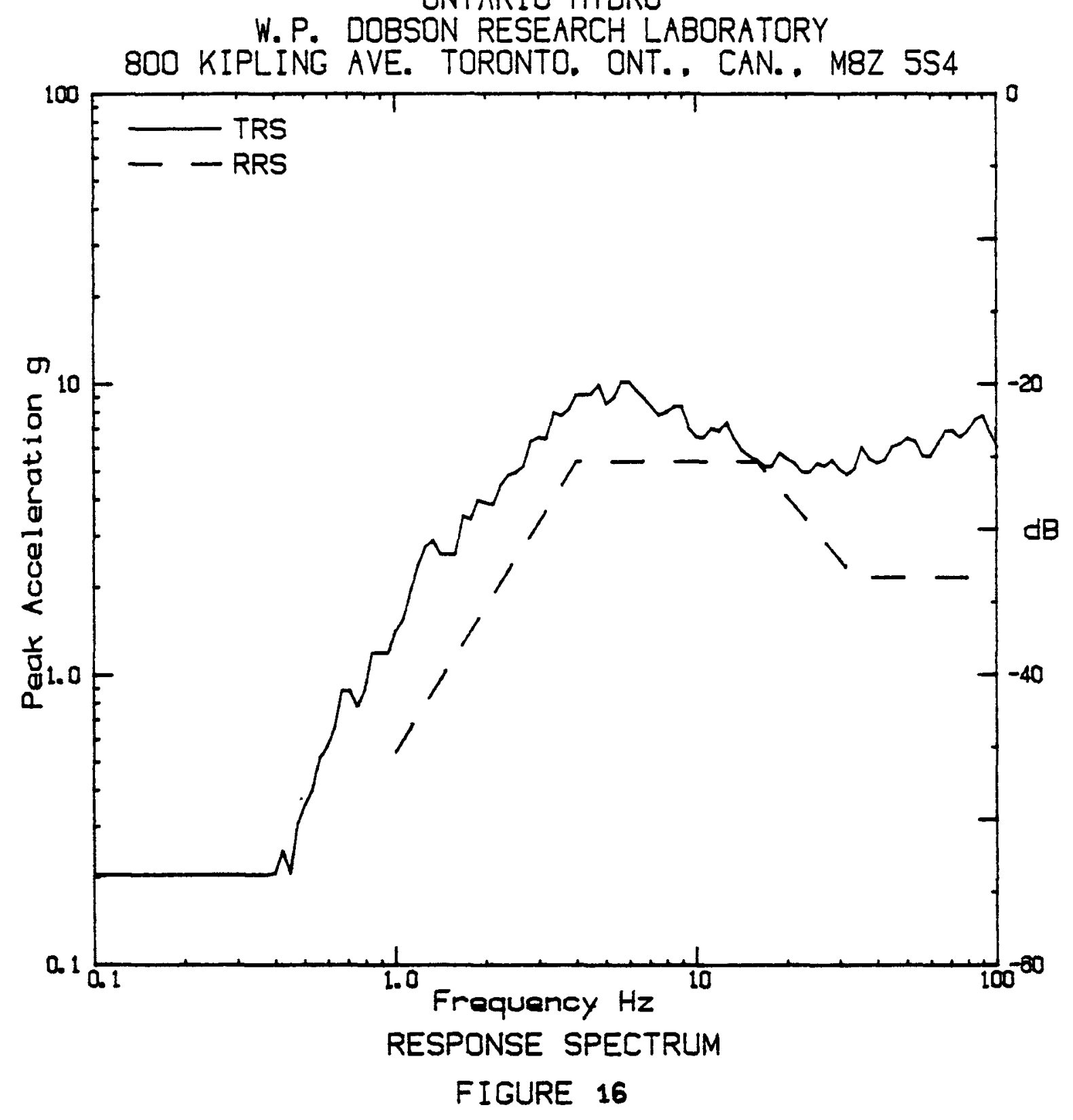

TEST ITEM

Station Calls \& Rack, Exida, Modal EMP-13, Sarial 43, 10, 4, 3, 45

PARTICULARS

July 26/84. Time 3z08. Temp('C) 23. Humidity (z) 55. Press (kPa) 100. Graph 5261

SPECIFICATIONS

Specs IEEE 501. Conditions operating: 1 hour rate. span 7

ANALYSIS

Type Maximax. Damping (x) 5, B. W. = 1/12 Detaves, Axis Y. Shaker tri-axial. ZPX=2.17g

ACCELEROMETER

Wilcoxon, Serial S761. Range dB49, Location base-mounting plate. Channel 2 


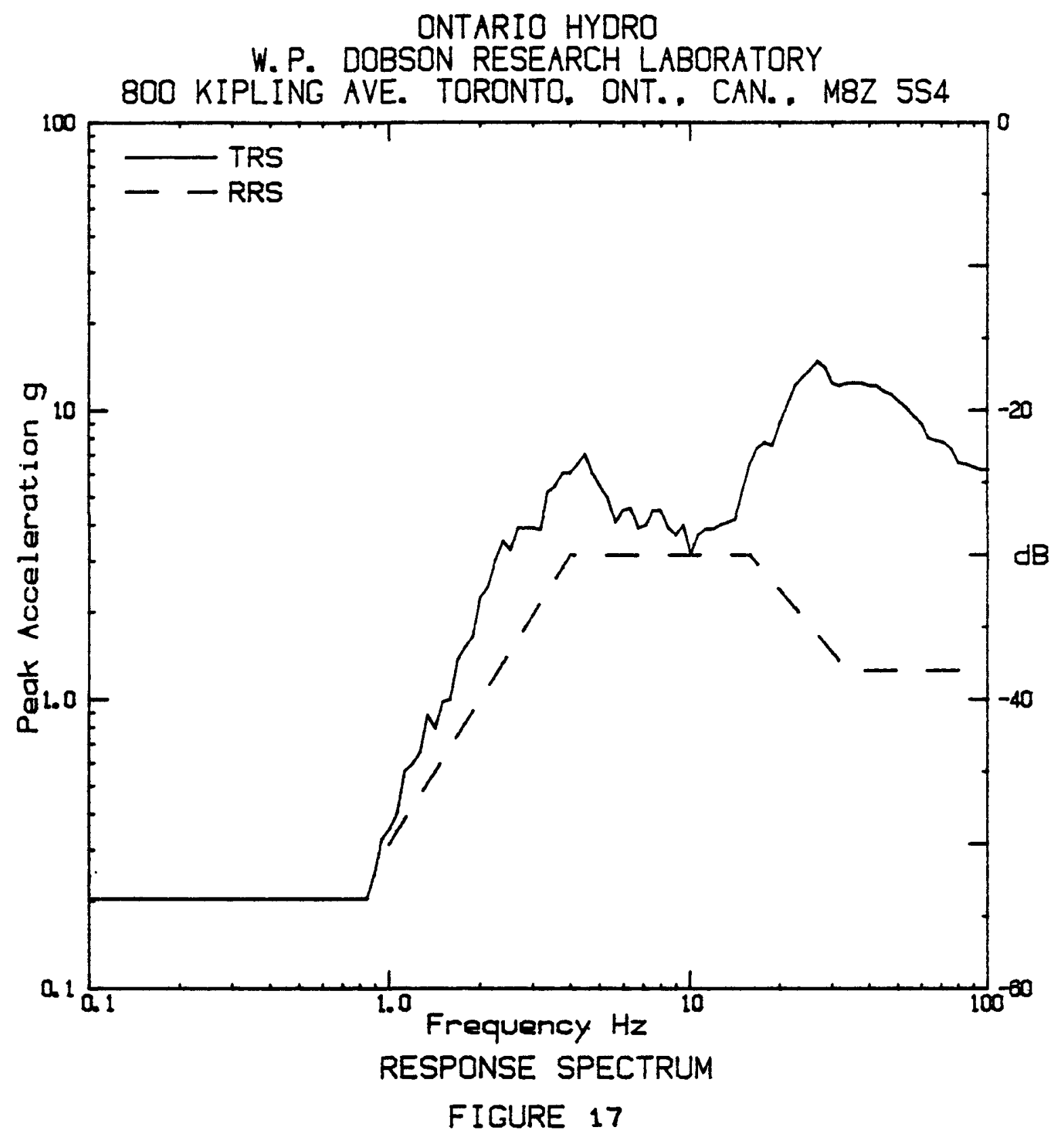

TEST ITEM

Station Calls \& Rack. Exide. Model EMP-13, Serial 43. 10. 4, 3. 45

PARTICULARS

July 26/84. Time 3308. Temp('C) 23. Humidity(z) 55. Press (kPa) 100 . Graph 5262

SPECIFICATIONS

Specs IEEE 501. Conditions operating : 1 hour rate, span 7

ANALYSIS

Type Maximax. Damping (Z) 5. B. $W_{0}=1 / 12$ Octaves, Axis $Z$. Shaker tri-axial, ZPX=1. 26g

ACCELEROMETER

Wilcoxon. Serial S759, Range dB49. Location base-mounting plate. Channel 3 


\title{
APPENDIX B
}

\begin{abstract}
Seismic Testing of Shippingport Nuclear Power station Batteries Cell Inspection and Capacity Tests
\end{abstract}

W. J. Janis

Ontario Hydro Reaserach Division 
To Mr. B.A. Oliver

Manager

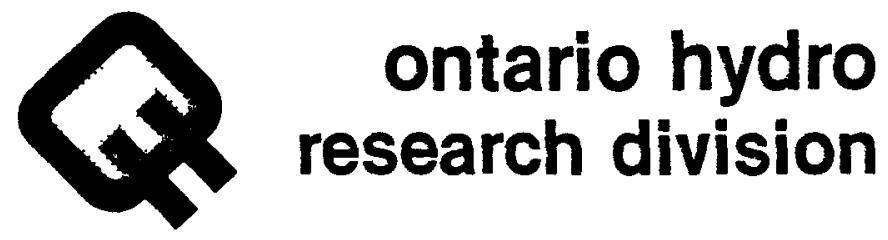

Electrical Design Dept

\begin{tabular}{c} 
SEISMIC TESTING OF SHIPPINGPORT NUCLEAR \\
POWER STATION BATTERIES - \\
CELL INSPECTION AND CAPACITY TESTS \\
\hline
\end{tabular}

W.J. Janis

The performance and condition of 27-year-old, antimony alloy, lead-acid cells were monitored before, during and after seismic testing to determine cell resistance to damage by seismic stresses. Nine EMP-13 cells were tested and none failed electrically during seismic testing. However, none of five seismically tested cells chosen for post-seismic capacity tests could deliver more than $39 \%$ of rated capacity after seismic testing. Low post-seismic capacities were primarily due to an appreciable loss of negative grid material, weakened bus/grid connections, clogged electrolyte channels and, possibly, corrosion product bridging negative and positive plates. Chemical corrosion of bus material may have been a contributing factor. Dissected cell negative plate surfaces were severely erupted and pitted and positive plate surfaces were choked with positive grid corrosion products.

\subsection{INTRODUCTION}

Sandia National Laboratories (SNL) is currently under contract to the United States Nuclear Regulatory Commission (NRC) to conduct studies on the degradation and failure modes of safety related components used in nuclear power plants. Of particular interest to SNL and NRC, and also to ontario Hydro, is the significance of aging on the seismic-accident survivability of stationary, Class IE, emergency power batteries.

Because of mutual interest, experience in seismic testing of batteries and the availability of special test facilities, ontario Hydro was sub-contracted by SNL to carry out seismic

\begin{tabular}{|l|l|l|l|l|}
\hline lob & fate & file 832.31 \\
$740632-168-950$ & X836.74 no. & January 31, 1985 & C84-121-P \\
\hline
\end{tabular}


fragility tests of naturally aged, lead-acid cells from the Shippingport Nuclear Power station, Shippingport, Pennsylvania. Following guidelines set out by $S N L$, a research program was developed by the Electrical Design Department (Design and Development Division), and the Mechanical and Chemical Research Departments (Research Division). In this program the performance and condition of aged cells were monitored before, during and after shaker table testing under simulated earthquake conditions.

This report presents cell condition and performance data obtained during the test program as applied to Shippingport EMP-13 type cells.

\subsection{TEST CELLS}

Twenty Exide EMP-13 cells were selected at random by Shippingport station personnel from a large number of cells recently released after 27 years of service. All were delivered to the Battery Research Facility, Ontario Hydro Kipling Complex, in good condition although slight spillage of sulphuric acid electrolyte had occurred during transport because of loose fitting filling caps.

The test cells were of the Plante, lead-antimony alloy type. That is all grid materials were composed of lead-antimony alloy and the positive plate active material was chemically produced from special, pure lead buttons imbedded in the positive grids. Cell specifications supplied by the manufacturer are given in Appendix 1 .

\subsection{EXPERIMENTAL}

\subsection{Cell Inspection and Initial Conditioning}

On delivery to Ontario Hydro Research Division (OHRD) the cells were inspected for leaks, excess sediment, broken posts, cracks, crazing and any damage which might have been induced by handling during transportation. No significant damage was observed for 16 of the cells and these cells were therefore put on equalizing, then floating charge at 2.25 and 2.15 Volts per cell (VPC), respectively. Four cells showed excessively low electrolyte levels and were discarded. Undamaged cells were placed on floating charge prior to, and between, capacity tests to minimize capacity loss through self-discharge.

During storage, the specific gravities of the cells were maintained between 1.200 and 1.220 , corrected to $25^{\circ} \mathrm{C}$ per IEEE standard 450-1980/1/. Specific gravities, cell voltages, electrolyte levels and temperatures were monitored and adjusted as necessary to maintain the cells in serviceable condition. 


\subsection{Initial Capacity Tests}

Following inspection, charge equalization, and a minimum of $24 \mathrm{~h}$ float charging, 12 serviceable cells selected at random from the set of 16 cells were discharged at the manufacturer's specified $3 \mathrm{~h}$ rate of $62 \mathrm{~A}$ to a final cell potential of $1.75 \mathrm{VPC}$. The discharge tests provided benchmark capacity data for cells selected for seismic test and were carried out per Reference 1 as follows:

1. Three or four cells and a resistance load were connected in series and the cells were discharged at a constant current following the procedure outlined in OHRD Report No $E 76-85-\mathrm{H} / 2 /$.

2. Cell potentials, discharge currents and temperatures were monitored during the discharge test. The data were recorded at 5 min intervals.

3. Discharged cells were recharged in series at a potential of $2.25 \mathrm{~V}$ for $35-70 \mathrm{~h}$, followed by sustained float charging at $2.15 \mathrm{~V}$.

\subsection{Cell Discharge During Seismic Testing}

Five of the 12 cells tested for capacity and four untested cells were submitted to seismic testing. To assess the immediate effect of a seismic event on cell performance, cells were kept on discharge during seismic tests and cell voltages and currents were monitored continuously during the tests. A $1.5 \mathrm{~h}$ discharge rate was used for the Shippingport cells to simulate a high load emergency service condition.

Discharge was initiated a few seconds prior to the first $30 \mathrm{~s}$ seismic event and was continued until the cell either failed during a seismic event or passed the scheduled sequence of seismic events. Failure was defined as the inability of a cell to maintain a potential greater than $1.75 \mathrm{~V}$ while under a constant current discharge at the $1.5 \mathrm{~h}$ rate.

\subsection{Post Seismic Capacity Tests}

After seismic testing, all cells which did not fail were discharged at the $3 \mathrm{~h}$ rate. The procedure was the same as for the initial capacity tests.

\subsection{Cell Disassembly and Material Studies}

Four test cells were disassembled following seismic and capacity testing to identify changes in internal components resulting 
directly from seismic testing. A photographic record of cell components was obtained. Representative photographs are presented as part of section 4.5 .

\subsection{RESULTS AND DISCUSSION}

\subsection{Cell Inspection}

Twenty cells from Shippingport NGS arrived at OHRD on March 2, 1984. None of the cells showed outward evidence of damage but four cells had abnormally low electrolyte levels due to spillage. All of the electrolyte levels were within the manufacturer's specified limits for the remaining 16 cells.

All 16 cells which passed visual inspection were put on equalizing charge on March 6, 1984. Specific gravities averaged $1.16 \pm 0.01$ when the cells were received and $1.21 \pm 0.01$ seven days later.

As expected for lead-antimony alloy cells, considerable sediment $(5-10 \mathrm{~mm})$ was observed during cell inspection.

\subsection{Initial Capacity Tests}

Capacity data and pre-test specific gravities and open circuit cell potentials are presented in Table $I$. Nine of twelve cells met the IEEE recommended acceptance criterion of $80 \%$ rated capacity.

After initial capacity tests, the cells were recharged at 2.15 VPC. After 6 days of float charging cell specific gravities averaged 1.207 and both open circuit voltages and charging current had stabilized. (Approximately 2.1 V and $3 \mathrm{~A}$ per cell, respectively.) Following Appendix B of IEEE Standard 450/1/, stabilization of the voltage-regulated charging current at the charging voltage of $2.15 \mathrm{VPC}$ was taken as an indication that the cells in question were charged. Five cells selected at random were therefore allowed to proceed to seismic testing.

\subsection{Cell Discharge During Seismic Testing}

No sudden loss of cell potential was observed for any cells during seismic testing up to the capacity of the shaker table. The pass/fail results are summarized in Table II and presented in more detail in Appendix 2. Details of the seismic testing procedure and fragility level assessment are presented in OHRD reports $B 84-44-P / 3 /$ and $B 84-428-P / 4 /$. 
TABLE I

CAPACITY TEST DATA*

\begin{tabular}{|c|c|c|c|c|}
\hline $\begin{array}{c}\text { Cell } \\
\text { Number }\end{array}$ & $\begin{array}{c}25^{\circ} \mathrm{C} \\
\text { Gravity } \\
\text { Prior to } \\
\text { Discharge }\end{array}$ & $\begin{array}{l}\text { Open } \\
\text { Circuit } \\
\text { Potential } \\
\text { (Volts) }\end{array}$ & $\begin{array}{l}\text { Time to } \\
1.75 \text { VPC at } \\
3 \mathrm{~h} \text { rate of } \\
62 \mathrm{~A} \text { (min) }\end{array}$ & $\begin{array}{c}\text { Percent } \\
\text { Rated } \\
\text { Capacity at } \\
3 \text { h Rate }\end{array}$ \\
\hline $\begin{array}{r}3 \\
4 \\
7 \\
9 \\
10 \\
12 \\
13 \\
15 \\
18 \\
43 \\
44 \\
45\end{array}$ & $\begin{array}{l}1.205 \\
1.210 \\
1.205 \\
1.210 \\
1.210 \\
1.205 \\
1.210 \\
1.200 \\
1.210 \\
1.200 \\
1.215 \\
1.210\end{array}$ & $\begin{array}{l}2.16 \\
2.19 \\
2.19 \\
2.16 \\
2.17 \\
2.19 \\
2.19 \\
2.08 \\
2.09 \\
2.17 \\
2.10 \\
2.10\end{array}$ & $\begin{array}{l}151 \\
167 \\
167 \\
151 \\
172 \\
167 \\
173 \\
143 \\
132 \\
177 \\
142 \\
147\end{array}$ & $\begin{array}{l}84 \\
93 \\
93 \\
84 \\
96 \\
93 \\
96 \\
46 \\
73 \\
98 \\
79 \\
82\end{array}$ \\
\hline
\end{tabular}

* Cells equalized at 2.25 VPC for 7 days, then float charged at 2.15 VPC for 26 days prior to discharge.

TABLE II

DISCHARGE DATA SUMMARY - SEISMIC EVENT TESTS

\begin{tabular}{|c|c|c|c|c|}
\hline \multirow{2}{*}{$\begin{array}{c}\text { Cell } \\
\text { Number }\end{array}$} & $\begin{array}{c}\text { Pass/Fail } \\
\text { at } 1.5 \mathrm{~h} \\
\text { Discharge } \\
\text { Rate* }\end{array}$ & \multicolumn{2}{|c|}{$\begin{array}{c}\text { Cell Potential (V) } \\
\text { While Under Load }\end{array}$} & $\begin{array}{c}\text { Total } \\
\text { Time on } \\
\text { Discharge } \\
\text { (s) }\end{array}$ \\
\cline { 3 - 5 } & $\begin{array}{c}\text { Before } \\
\text { Testing }\end{array}$ & $\begin{array}{c}\text { After } \\
\text { Testing }\end{array}$ & \\
\hline 1 & Pass & 1.99 & 1.93 & 240 \\
$3 * *$ & Pass & 1.88 & 1.84 & 435 \\
$4 * *$ & Pass & 1.88 & 1.84 & 435 \\
5 & Pass & 1.97 & 1.93 & 180 \\
8 & Pass & 1.96 & 1.92 & 180 \\
$10 * *$ & Pass & 1.88 & 1.84 & 435 \\
11 & Pass & 1.94 & 1.91 & 218 \\
$43 * *$ & Pass & 1.88 & 1.84 & 435 \\
$45 * *$ & Pass & 1.88 & 1.84 & 435 \\
\hline
\end{tabular}

* 96 Amperes

** Multi-cell test ( 5 cells connected in series) 
The data in Table II indicate that all Shippingport test cells survived seismic stress up to the capacity of the shaker table test equipment.

\subsection{Post Seismic Capacity Tests}

Post test discharge capacities were determined for five of the cells which survived seismic testing. The data are compared to pre-seismic values in Table III. Also in Table III is the cumulative capacity for the cells, as measured from the start of the seismic test, expressed as a percentage of the $3 \mathrm{~h}$ rated capacity. The required calculations to convert discharge times at the $1.5 \mathrm{~h}$ rate to discharge times at the $3 \mathrm{~h}$ rate is provided in Appendix 3 .

\section{TABLE III}

\section{CELL CAPACITIES BEFORE AND AFTER SEISMIC TESTING}

\begin{tabular}{|c|c|c|c|c|c|c|}
\hline \multirow[b]{2}{*}{ Cell } & \multicolumn{3}{|c|}{$\begin{array}{l}\text { Time to } 1.75 \mathrm{VPC} \\
\text { at } 3 \mathrm{~h} \text { Rate (min) }\end{array}$} & \multicolumn{3}{|c|}{$\begin{array}{c}\text { Per Cent of Rated Capacity } \\
\text { at } 3 \mathrm{~h} \text { Rate }\end{array}$} \\
\hline & $\begin{array}{l}\text { Pre- } \\
\text { Seismic }\end{array}$ & $\begin{array}{c}\text { Post- } \\
\text { Seismic* }\end{array}$ & $\begin{array}{c}\text { Post- } \\
\text { Seismic } \\
\text { Plus } \\
\text { Seismic** }\end{array}$ & $\begin{array}{c}\text { Pre- } \\
\text { Seismic }\end{array}$ & $\begin{array}{l}\text { Post- } \\
\text { Seismic* }\end{array}$ & $\begin{array}{c}\text { Post-Seismic } \\
\text { Plus } \\
\text { Seismic** }\end{array}$ \\
\hline $\begin{array}{r}3 \\
4 \\
10 \\
43 \\
45\end{array}$ & $\begin{array}{l}151 \\
167 \\
172 \\
177 \\
147\end{array}$ & $\begin{array}{l}10 \\
25 \\
25 \\
45 \\
40\end{array}$ & $\begin{array}{l}24 \\
39 \\
39 \\
59 \\
54\end{array}$ & $\begin{array}{l}84 \\
93 \\
96 \\
98 \\
82\end{array}$ & $\begin{array}{r}4 \\
14 \\
14 \\
25 \\
22\end{array}$ & $\begin{array}{l}13 \\
22 \\
22 \\
33 \\
30\end{array}$ \\
\hline AVG & 163 & 29 & 43 & 91 & 16 & 24 \\
\hline
\end{tabular}

* Cells not recharged following seismic testing.

* * Capacity during seismic test at $1.5 \mathrm{~h}$ rate converted to $3 \mathrm{~h}$ capacity and added to post-seismic capacity, as discussed in Appendix 3 .

The Table III data indicate a significant loss of discharge capacity for all cells as a result of seismic testing.

\subsection{Cell Disassembly and Material Study}

Seismically tested cells 43 and 45 and non-seismically tested, low capacity cell 15 were disassembled and inspected for internal damage. Common features identified during the inspection are documented in Photographs $1-5$ and summarized below. 
Photograph 1 shows cell posts and buses of a typical EMP-13 cell (cell 15) as they appear when the cell jar top is removed and the cell drained of electrolyte. The dark flakes in the photograph are corrosion products dislodged from the positive plate grids. White flakes are case shavings produced when the cell top was removed. All EMP-13 cells examined contained large amounts of the flakes in the sediment spaces, on top of the plate packs, and loosely attached to the positive buses and terminal posts. The horizontal plates at the extreme left and right of photograph 1 are the negative and positive buses, respectively. The cell plates are attached to the buses from plate hangers directly beneath the buses. No cracks were observed in post or bus materials when the cells were opened.

Photograph 2 shows the result of two moderate hammer blows to the negative post of cell 15. The first blow broke all top grid edges while the second easily bent the bus/plate hanger assembly away from the plate pack. In all dissected cells the negative plate grids were very weak and brittle at their tops. In cells 43 and 45 considerable negative plate material, particularly at the tops of the plates near the plate hangers, was loose, presumably as a result of seismic testing.

Photograph 3 shows the result of several moderate hammer blows to the positive post of cell 15. The bus material was relatively brittle and the bus fractured as the post was hammered. The dark portions in the bus cross-section of photograph 3 identify areas where some chemical attack has taken place. The attack is most severe on the underside of the bus and decreases as the cross-section is traversed from bottom to top.

Most negative plates of the three dissected cells were severely erupted on both sides, as shown in photograph 4 (cell 43). Non-erupted, vertical areas of photograph 4 correspond to the positions of plastic spacers. The spacers appear to have restricted chemical activity where they contacted the negative plates and therefore enhanced chemical activity in the erupted areas and plate extremities.

Photograph 5 shows a typical positive plate from cell 43 . The positive plates were quite solid and were not warped. Lead buttons, the circular structures of photograph 5, near the extremities of the plates were usually clogged with active lead oxides, The buttons in the centers of most plates were not so densely packed with oxides, indicating less frequent participation of these buttons in cell reactions.

All positive grids showed evidence of flaking (the loose background material of photographs 1,4 and 5) and in seismically tested cells the flaked material was distributed on the tops of the plate packs, deposited in the sediment space and lodged between positive plates and adjacent separators. 


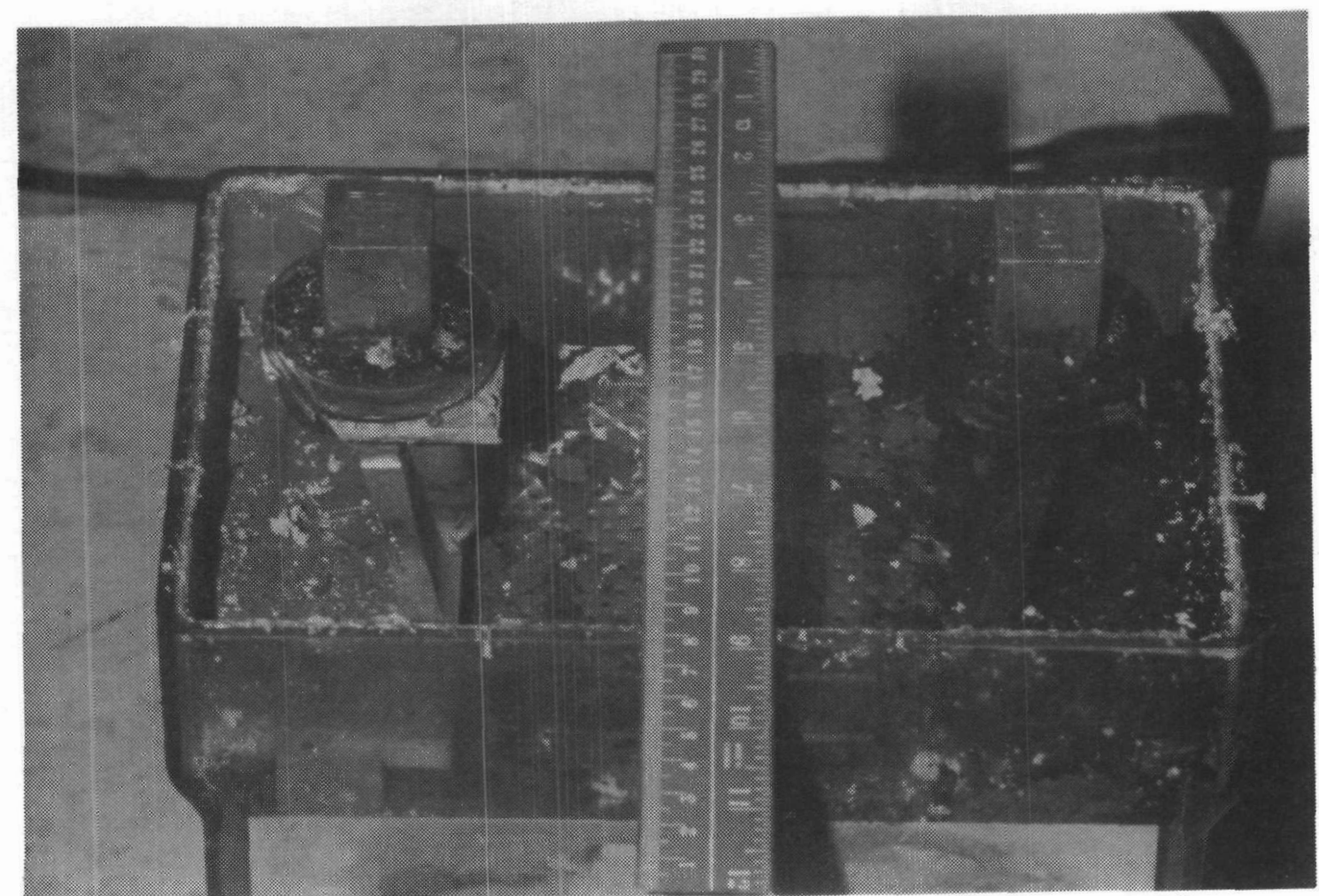

(1)

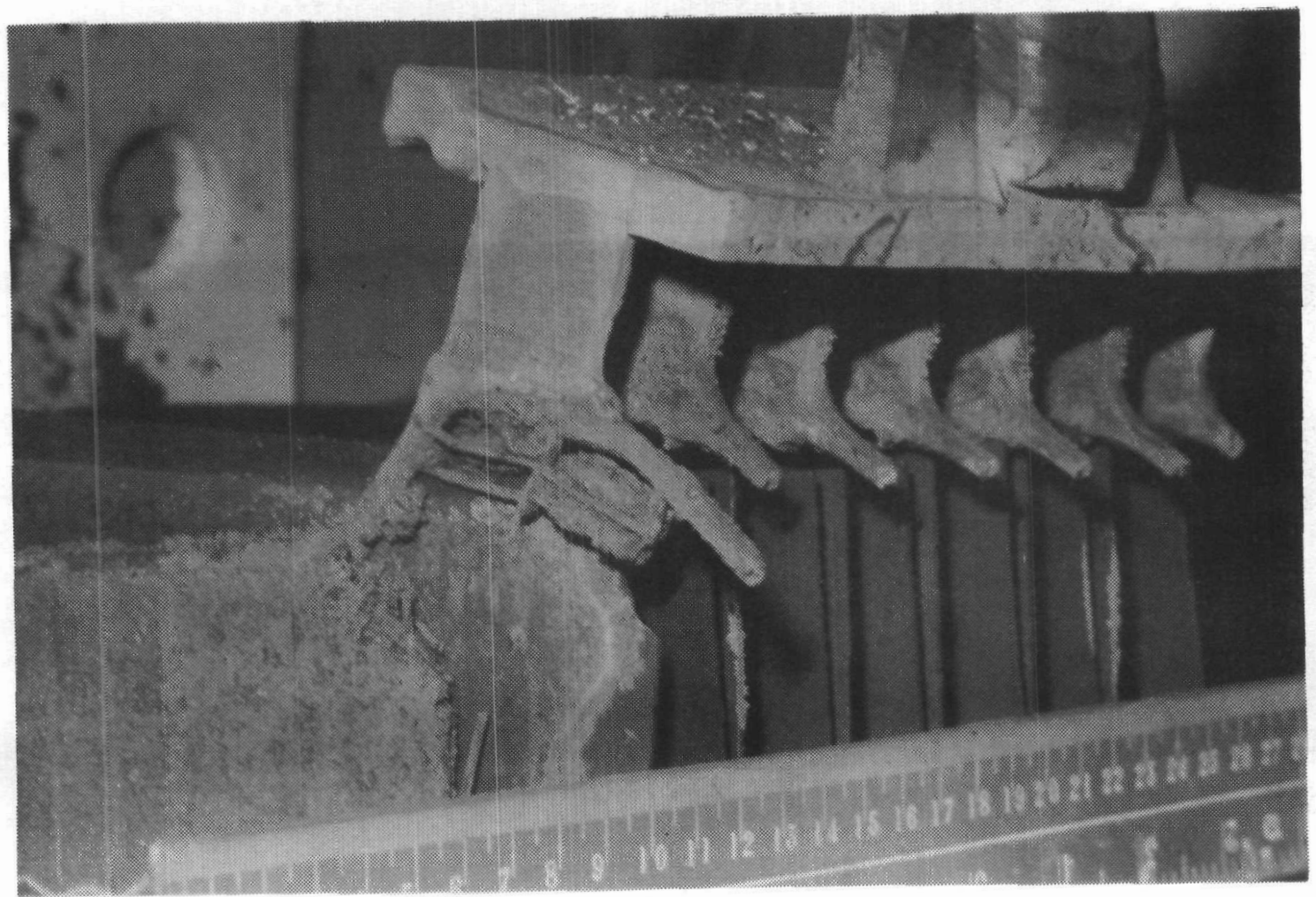

(2)

$\mathrm{B}-8-$

C84-12I 


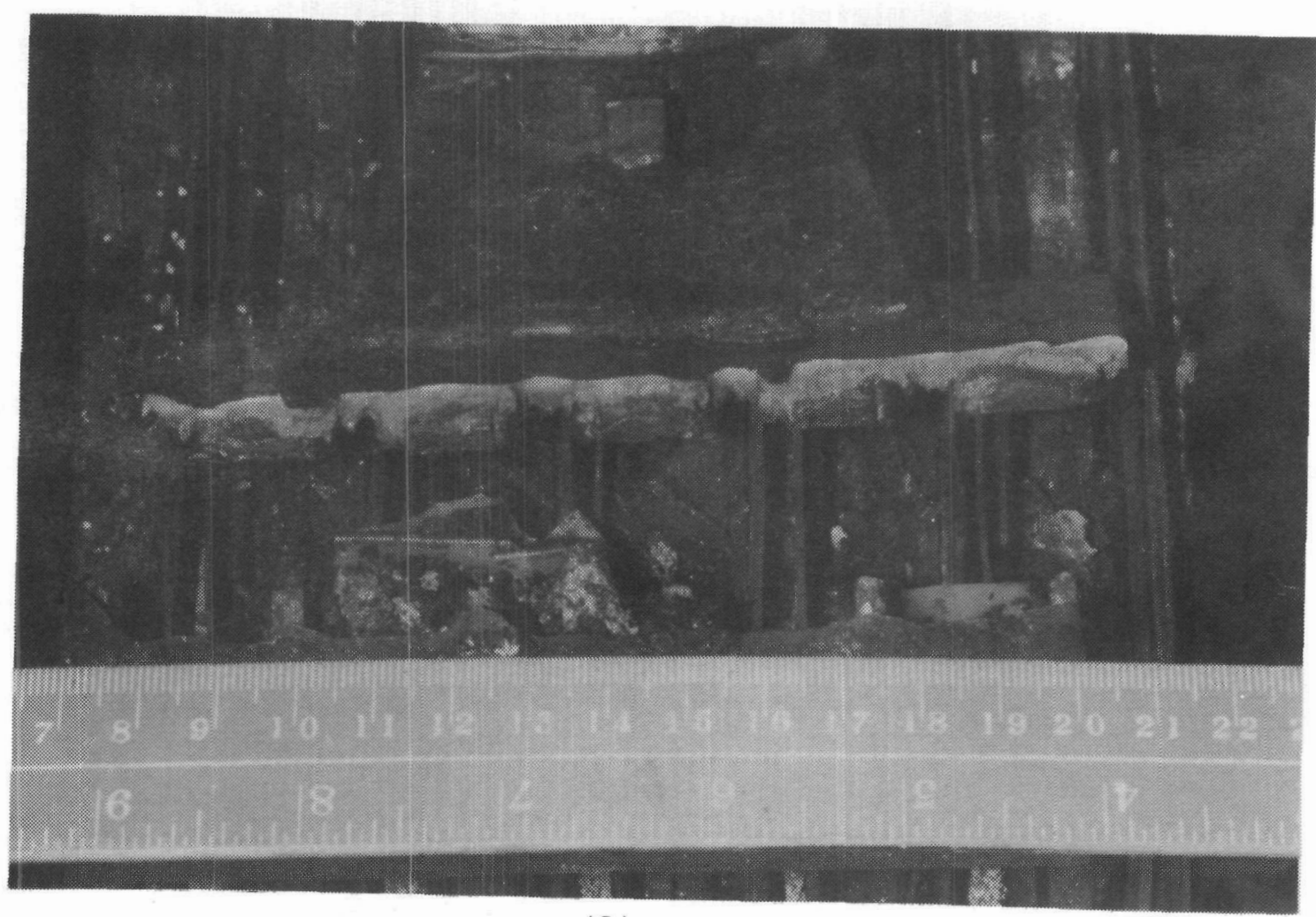

(3)

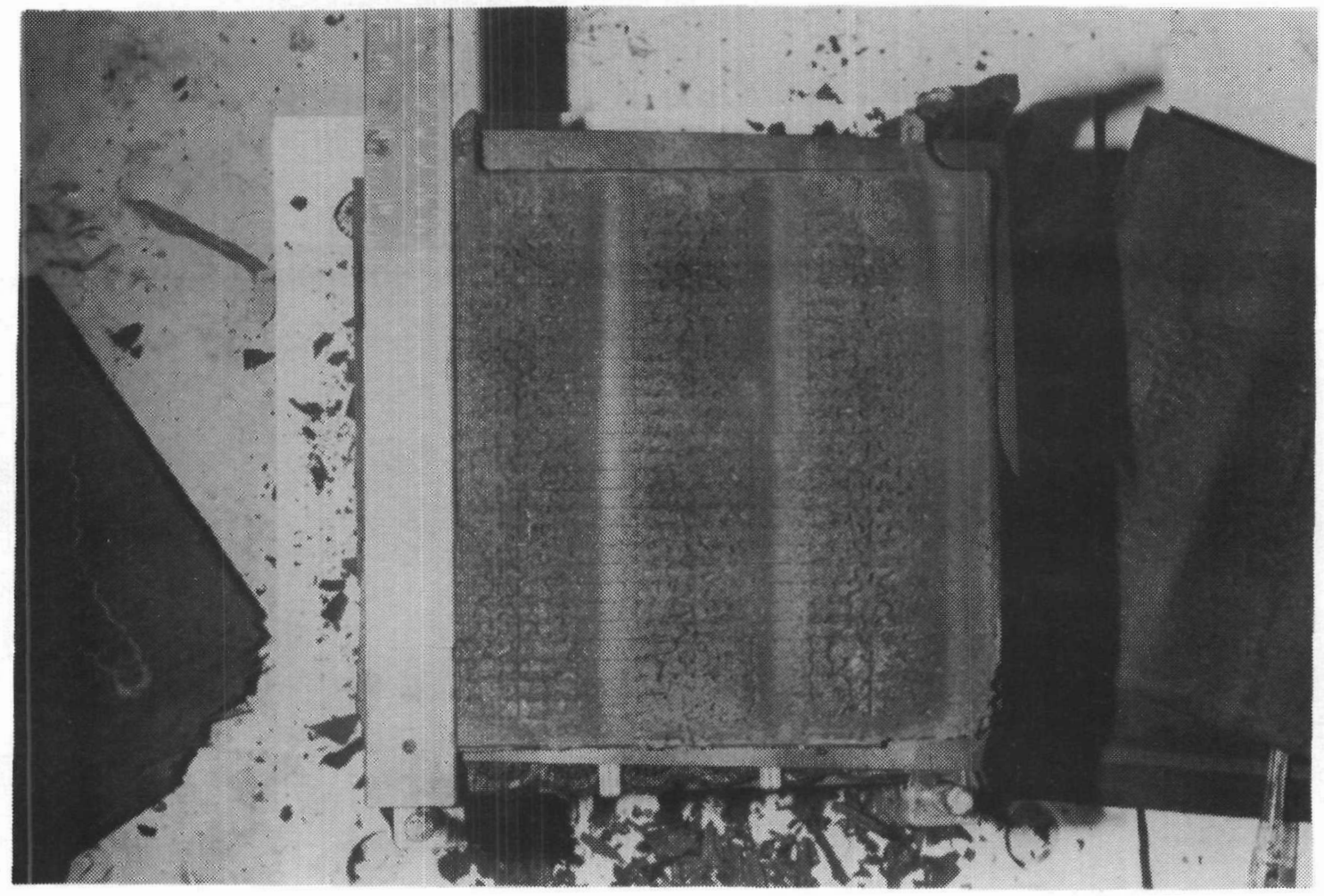

(4)

B-9-

C84-121 
DOCUMENTATION PHOTOGRAPHS

SHIPPINGPORT LEAD-ANTIMONY CELLS (EMP-13)

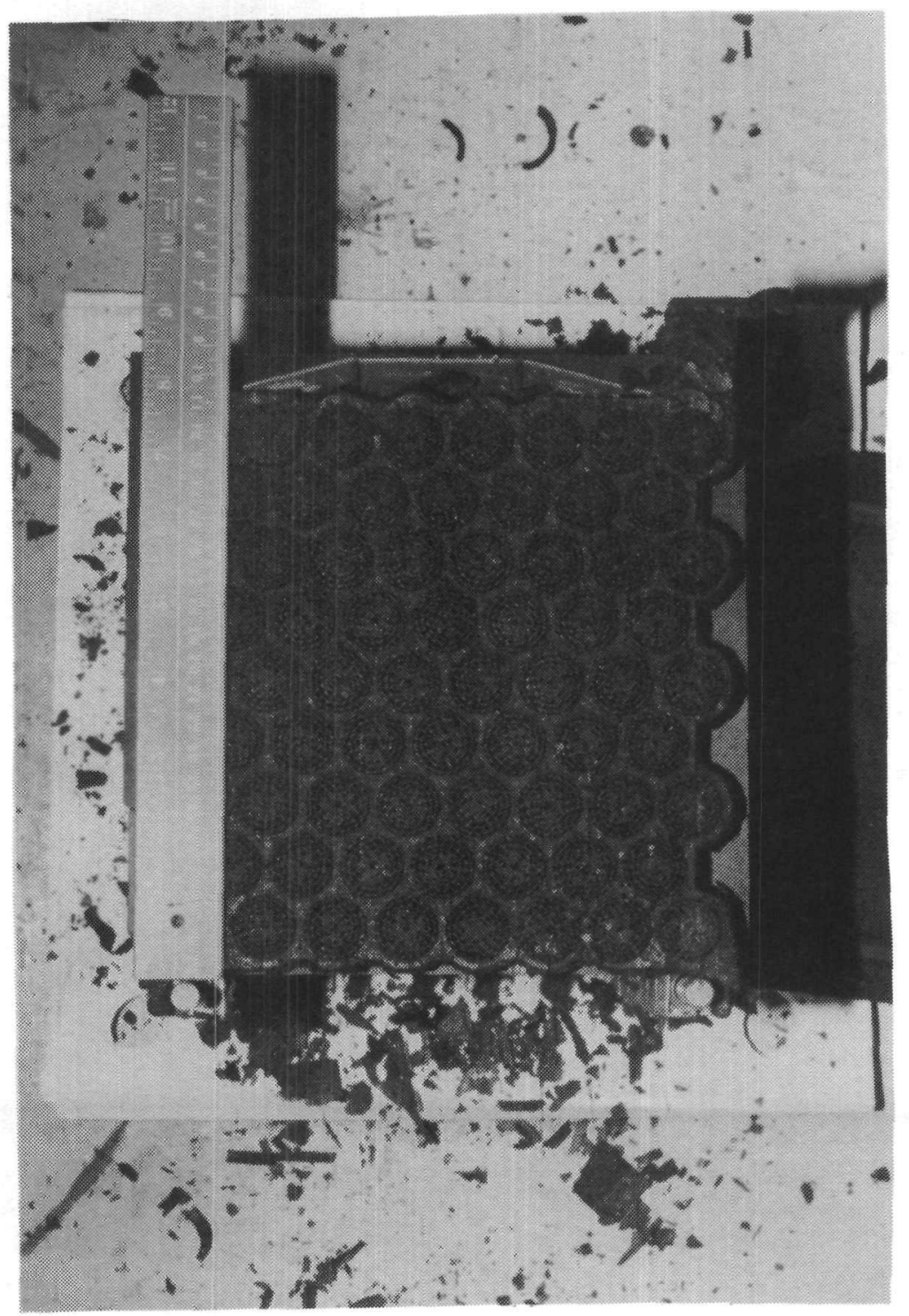

(5)

B-10- 


\section{CONCLUSION}

1. All nine EMP-13 cells selected for seismic testing provided uninterrupted power at required electrical potential under load during repeated and violent shaking.

2. All five EMP-13 cells tested for discharge capacity following seismic testing failed to meet the acceptance criterion of $80 \%$ of rated capacity due to internal damage suffered during shaking.

3. Internally, the 27-year old EMP-13 cells were in poor condition prior to seismic testing. Negative plates in the vicinity of bus connections were extremely weak, positive buses were corroded and brittle, negative and positive active material utilization was extremely uneven and corrosion products, mostly from the positive grids, littered the cells. Seismic testing dislodged active negative material, weakened plate attachments and clogged electrolyte channels with dislodged corrosion products.

Approved by:

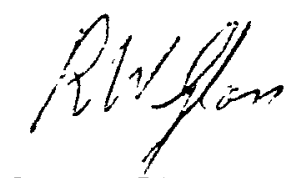

R.W. Glass

Section Head

Chemical Research Dept
Prepared by:

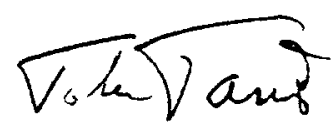

W.J. Janis

Chemist

Organic Section

WJJ : Ig 


\section{REFERENCES}

1. Bellack, J.H., "IEEE Recommended Practice for Maintenance, Testing and Replacement of Large Lead storage Batteries for Generating Stations and Substations". IEEE Std 450-1980, (October 1980).

2. Stelter, M.K.G., "Battery Discharge Load for Seismic Tests", Ontario Hydro Research Division Report No E76-85-H, (November 1976).

3 Black, D.A. and G.D. Paulsen, "Seismic Testing of Exide Aged Batteries", Ontario Hydro Research Division Report No B84-44-P, (June 1984).

4. Black, D.A. and G.D. Paulsen, "Seismic Testing of Aged Shippingport Nuclear Power Plant Batteries", Ontario Hydro Research Division Report No 84-428-P, (December 1984).

5. Vinal, G.S., Storage Batteries, Fourth Edition, J. Wiley and Sons, New York (1955). 


\section{APPENDIX 1 \\ TEST CELL SPECIFICATIONS - EMP-13 CELLS}

(a) Capacity

\begin{tabular}{|c|c|c|c|c|}
\hline \multicolumn{3}{|c|}{ Discharge Rate to $1.75 \mathrm{~V}$ Per Cell at $25^{\circ} \mathrm{C}$ (Amperes) } \\
\hline For $8 \mathrm{~h}$ & For $5 \mathrm{~h}$ & For $3 \mathrm{~h}$ & For $1.5 \mathrm{~h}$ & For $\mathrm{I} \mathrm{h}$ \\
\hline 30 & 44 & 62 & 96 & 120 \\
\hline
\end{tabular}

(b) Dimensions

\begin{tabular}{|l|c|c|c|c|}
\hline & Height (cm) & Width (cm) & Length (cm) & Thickness (cm) \\
\hline Overall & 45.5 & 25.7 & 17.5 & -- \\
\hline $\begin{array}{l}\text { Positive } \\
\text { Plate }\end{array}$ & 19.7 & 19.7 & -- & 1.12 \\
\hline $\begin{array}{l}\text { Negative } \\
\text { Plate }\end{array}$ & 19.7 & 19.7 & -- & 0.46 \\
\hline
\end{tabular}

\section{(c) Materials}

\begin{tabular}{|c|c|}
\hline Container & $\begin{array}{l}\text { Transparent Polystyrene Case } \\
\text { Opaque Styrene-butadiene Cover }\end{array}$ \\
\hline Separators & microporous rubber \\
\hline $\begin{array}{l}\text { Positive Plate active } \\
\text { material retainers }\end{array}$ & fiberglass mat \\
\hline Electrodes & $\begin{array}{c}\text { lead-antimony grid ( } 6 \text { positive, } \\
7 \text { negative) }\end{array}$ \\
\hline Posts and Buses & $\begin{array}{c}1 \text { positive post, } 1 \text { negative post, } \\
2.5 \mathrm{~cm} \mathrm{x} 2.5 \mathrm{~cm} \text { each, attached to } \\
\text { to lead bus. }\end{array}$ \\
\hline Electrolyte & $\begin{array}{c}1.215 \text { specific gravity sulphuric } \\
\text { acid }\left(25^{\circ} \mathrm{C}\right)\end{array}$ \\
\hline
\end{tabular}

1 Note: Buses are sometimes referred to as straps. 
APPENDIX 2

DISCHARGE DATA - SEISMIC EVENT TESTS

\begin{tabular}{|c|c|c|c|c|c|c|}
\hline \multirow[b]{2}{*}{$\begin{array}{c}\text { Cell } \\
\text { Number }\end{array}$} & \multicolumn{3}{|c|}{ Seismic Event Data } & \multicolumn{3}{|c|}{ Cell Potential Data } \\
\hline & $\begin{array}{l}\text { Event } \\
\text { Number }\end{array}$ & $\begin{array}{c}\text { Intensity } \\
\text { Setting }\end{array}$ & $\begin{array}{c}\text { Relative } \\
\text { Start } \\
\text { Time } \\
\text { (s) }\end{array}$ & $\begin{array}{l}\text { At start } \\
\text { of } \\
\text { Seismic } \\
\text { Event } \\
\text { (V) }\end{array}$ & $\begin{array}{l}\text { At End } \\
\text { of } \\
\text { Seismic } \\
\text { Event } \\
\text { (V) }\end{array}$ & $\begin{array}{c}\text { Difference } \\
\text { (End- } \\
\text { Start) } \\
(\mathrm{mV})\end{array}$ \\
\hline $\begin{array}{ll}3 *, & 4, \\
10, & 43 \\
\text { and } & 45\end{array}$ & $\begin{array}{l}1 \\
2 \\
3 \\
4\end{array}$ & $\begin{array}{c}4 \\
5 \\
6 \\
6.8\end{array}$ & $\begin{array}{c}0 \\
84 \\
182 \text { ** } \\
245\end{array}$ & $\begin{array}{l}1.882 \\
1.832 \\
1.837 \\
1.844\end{array}$ & $\begin{array}{l}1.839 \\
1.834 \\
1.838 \\
1.839\end{array}$ & $\begin{array}{r}-43 \\
2 \\
1 \\
-5\end{array}$ \\
\hline 1 & $\begin{array}{l}1 \\
2 \\
3 \\
4\end{array}$ & $\begin{array}{c}4 \\
5 \\
6 \\
6.8\end{array}$ & $\begin{array}{r}0 \\
63 \\
126 \\
175\end{array}$ & $\begin{array}{l}1.991 \\
1.915 \\
1.922 \\
1.931\end{array}$ & $\begin{array}{l}1.937 \\
1.917 \\
1.927 \\
1.934\end{array}$ & $\begin{array}{r}-54 \\
2 \\
5 \\
3\end{array}$ \\
\hline 5 & $\begin{array}{l}1 \\
2 \\
3 \\
4\end{array}$ & $\begin{array}{c}4 \\
5 \\
6 \\
6.8\end{array}$ & $\begin{array}{c}0 \\
42 * * \\
84 \\
133\end{array}$ & $\begin{array}{l}1.967 \\
1.956 \\
1.923 \\
1.926\end{array}$ & $\begin{array}{l}1.936 \\
1.930 \\
1.924 \\
1.929\end{array}$ & $\begin{array}{r}-31 \\
-26 \\
1 \\
3\end{array}$ \\
\hline 8 & $\begin{array}{l}1 \\
2 \\
3 \\
4\end{array}$ & $\begin{array}{c}4 \\
5 \\
6 \\
6.8\end{array}$ & $\begin{array}{r}0 \\
35 \\
77 \\
119\end{array}$ & $\begin{array}{l}1.957 \\
1.920 \\
1.917 \\
1.924\end{array}$ & $\begin{array}{l}1.928 \\
1.915 \\
1.921 \\
1.925\end{array}$ & $\begin{array}{r}-29 \\
-5 \\
3 \\
1\end{array}$ \\
\hline 11 & $\begin{array}{l}1 \\
2 \\
3 \\
4\end{array}$ & $\begin{array}{c}4 \\
5 \\
6 \\
6.8\end{array}$ & $\begin{array}{r}0 \\
42 \\
84 \\
126\end{array}$ & $\begin{array}{l}1.930 \\
1.899 \\
1.897 \\
1.907\end{array}$ & $\begin{array}{l}1.905 \\
1.895 \\
1.904 \\
1.909\end{array}$ & $\begin{array}{r}-25 \\
-4 \\
7 \\
-2\end{array}$ \\
\hline
\end{tabular}

* Multi-Cell Test (cell potential data are averages).

* Does not include a 10-15 minute stoppage to tighten loose connections. The stoppage caused a first attempt at setting 5 to be abandoned in the test of cell 5 . 


\section{APPENDIX 2 (cont'd)}

\section{Notes}

1. Seismic test event duration $=30 \mathrm{~s}$ in all cases.

2. The relative start time zero is coincident with the initiation of the first 30 s seismic event.

3. The cell failure criterion is a sharp cell potential drop to $<1.75$ VPC.

4. The maximum accelerations for the intensity settings are approximately as follows:

\begin{tabular}{l} 
Intensity \\
Setting \\
\hline
\end{tabular}

2

3

4

5

6

6.8 (machine limit)
Maximum

Acceleration (g)

2

3

4

5

6

6.5 


\section{APPENDIX 3}

\section{DISCHARGE TIME/RATE CALCULATIONS}

Discharge Time at Nominal $1.5 \mathrm{~h}$ Rate-Converted to Discharge Time at Nominal $3 \mathrm{~h}$ Rate

The most widely used and accepted equation relating discharge current and time i's Peukert's equation/5/:

$$
I^{n} t=c
$$

[A3.1]

where $I$ and $t$ are the discharge current and time, respectively, and $n$ and $C$ are temperature dependent constants. The constants $n$ and $C$ may be evaluated by tests made on any cell or battery at at least two different rates of discharge at constant temperature.

Results of a linear regression analysis of $\log _{e}(t)$ versus $\log _{e}(I)$, using the $I$ and $t$ data of Appendix 1 , are summarized in Table A3.1. An approximate empirical relation for the discharge rate, in amperes, as a function of the discharge time, in hours, is as follows:

$$
I=\left(7.0392 \times 10^{-4} t\right)^{-0.6644}
$$

TABLE A3.1

$$
\text { LINEAR REGRESSION FIT - LOG }{ }^{(t)} \text { VERSUS LOGe }(I)
$$

\begin{tabular}{|c|c|c|c|l|}
\hline $\begin{array}{c}t \\
(h)\end{array}$ & $\log _{e}(t)$ & $\begin{array}{c}I \\
\text { (amperes) }\end{array}$ & $\log _{e}(I)$ & \multicolumn{1}{|c|}{$\begin{array}{c}\text { Curve Fitting } \\
\text { Parameters }\end{array}$} \\
\hline 8 & 2.079 & 30 & 3.401 & Slope $(-n)=-1.5052$ \\
5 & 1.609 & 44 & 3.784 & y-intercept (Log $(c))=7.259$ \\
3 & 1.099 & 62 & 4.127 & correlation \\
1.5 & 0.405 & 96 & 4.564 & coefficient = -0.998 \\
1 & 0.000 & 120 & 4.787 & \\
\hline
\end{tabular}


From relation [A3.1], discharge currents at different discharge times are related by:

$$
t_{2}=\left(\frac{I_{1}}{I_{2}}\right)^{n} \cdot t_{1}
$$

where the subscripts refer to different $(I, t)$ pairs.

Equation [A3.3], with $n=1.5052$, was used to calculate $3 \mathrm{~h}$ rate data using $1.5 \mathrm{~h}$ rate data, and the results are shown in Table A3.2.

TABLE A3.2

DISCHARGE TIME CONVERSION (1.5 h RATE TO 3 h RATE)

\begin{tabular}{|c|c|c|c|c|}
\hline \multirow{2}{*}{$\begin{array}{l}\text { Cel1 } \\
\text { Number }\end{array}$} & \multicolumn{2}{|c|}{1.5 h Rate Discharge } & \multicolumn{2}{|c|}{3 Rate Discharge } \\
\hline & $\begin{array}{l}\text { Time } \\
\text { (s) }\end{array}$ & $\begin{array}{c}\text { Current (A) } \\
\text { (nominal) }\end{array}$ & $\begin{array}{c}\text { Time (s) } \\
\text { (calculated) }\end{array}$ & $\begin{array}{c}\text { Current (A) } \\
\text { (nominal) }\end{array}$ \\
\hline $\begin{array}{l}3,4 \\
10,43 \\
\text { and } \\
45 \text { in } \\
\text { series }\end{array}$ & 435 & 96 & 840 & 62 \\
\hline
\end{tabular}




\title{
APPENDIX C
}

Seismic Testing of

Exide Aged Batteries

\author{
D. A. Black
}

G. D. Paulsen

Ontario Hydro Reaserach Division

$c-i$ 
To Mr. B.A. Oliver

Manager

Electrical Design

Design \& Development

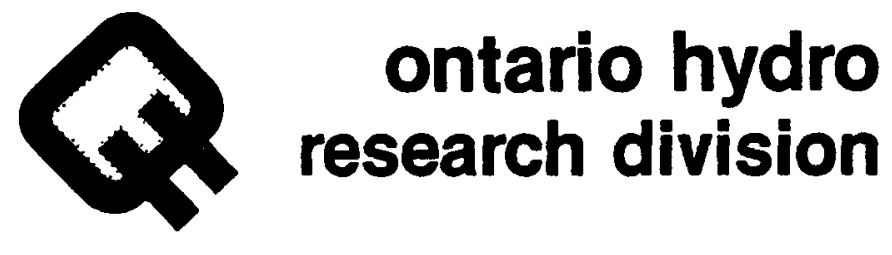

\author{
SEISMIC TESTING OF \\ EXIDE AGED BATTERIES \\ D.A. Black and G.D. Paulsen
}

Four naturally aged Exide cells were seismically tested to IEEE specifications. The testing was part of a program to determine the effects of aging on the ability of station cells to withstand seismic events. This report describes the test equipment used, the test procedure followed and gives the results of the tests.

\title{
1.0 INTRODUCTION
}

Four Exide cells were seismically tested to IEEE $344 / 1 /$ and IEEE 501/2/ specifications. Date of test, specimen description, test facility name and location, test data and test temperature, humidity and pressure are recorded on each of the response spectrum curves. These curves also show the conditions of the test, the type of analysis, the accelerometers used, the direction of the test, and the axis analysed. All tests were analysed using 5 of damping and the maximax shock spectrum. The tests performed were tri-axial tests as defined in IEEE 344. The shaker inputs were pseudo-random with a duration of $30 \mathrm{~s}$. All technical terms used in this report are defined by Harris/3/.

\subsection{SAMPLE}

The samples tested were described as follows:

Exide, Model EMP13, Serial Numbers 8, 1, 5 and 11, used cells approximately 27 years old.

\begin{tabular}{|l|l|l|l|l|}
\hline 100 & date & June 28, 1984 & B8 $84-44-\mathrm{P}$ \\
\hline
\end{tabular}




\subsection{TEST EQUIPMENT}

3.1 Equipment Used

3.1.1 Shaker Control Equipment

1. MTS 436 control units

2. MTS 406.11 controllers

3 MTS hydraulic pumps

4. Ontario Hydro noise generators and filters

5. Ontario Hydro tri-axial shaker table.

\section{1 .2 Analysis}

1. Columbia Model 9000 amplifiers and matching Wilcoxon M-408 accelerometers.

Amplifier

Serial No

$\begin{array}{lll}368 & 1632\end{array}$

$\begin{array}{lll}368 & 1633\end{array}$

$368 \quad 1634$

$368 \quad 1635$

$368 \quad 1636$

$\begin{array}{ll}368 & 1637\end{array}$

3691638

3691639

3691640

3691641

$369 \quad 1642$

3691643
Accelerometer Serial No

2. SE tape recorder Model 7000A, Serial No 547.

3. Tektronix 5113 dual beam storage oscilloscope, KS3681.

4. Spectral Dynamics 13231 Shock Spectrum Analyser, Serial No 27.

5. Spectral Dynamics 13191 Transient Memory, Serial No 29.

6. Ontario Hydro transmissibility circuit.

7. Watanabe WX4400 X-Y Recorder, Serial No 83010070.

8. Hewlett-Packard 7046A X-Yl-Y2 Recorder, Serial No 1914 A05842.

9. Spectral Dynamics 5012lL Tracking Filter, Serial No 171 . 
10. Spectral Dynamics SD122L Tracking Filter, Serial No 370 .

11. Honeywell 1858 oscillograph, Serial No $2649 \mathrm{JF} 78$.

12. Nicolet Scientific Corp, Model 660A Dual Channel FFT Analyzer, Serial No 9866226.

13. Hewlett-Packard Model 7470A Plotter, Serial No $2210 A-12990$.

\subsubsection{Calibration Equipment}

1. Bruel and Kjaer Type 3506, Serial No 877022

Accelerometer Calibration set which includes Type 2626, Serial No 842947 and Type 83055, Serial No 858627 , traceable to NBS.

2. General Radio 1557-A vibration calibrator, Serial No 2379 .

3. Data'Precision 2440 digital voltmeter, Serial No 8583, traceable to NBS.

4. Data Precision 248 digital voltmeter, Serial No 8583, traceable to NBS.

4.0 TESTS AND PROCEDURES

4.1 Calibration Procedure

Accelerometers and amplifiers are calibrated using the backto-back calibration procedure. The reference accelerometer was mounted on the vibration calibrator with the wilcoxon accelerometer. Using $100 \mathrm{~Hz}$ sine wave vibration of approximately $1 . \mathrm{g}$, the sensitivity of the Columbia amplifiers was set to give 500 $\mathrm{mV} / \mathrm{g}$ output. The outputs were measured using the digital voltmeter. By using the same voltmeter for both the reference and the Columbia amplifiers, slight differences in voltmeters need not be considered. Since the voltmeter measures true RMS voltages, the waveshapes of the $100 \mathrm{~Hz}$ signals were compared on the oscilloscope. This ensures that the signals are equivalent.

\subsection{Test Setup and Procedures}

Each cell was mounted in the fixture as shown in Figure 1. Accelerometers were placed at the base and on one terminal post. Electrical connections were made and the cell loaded to the 3hour rating by Chemical Research. The cells were then subjected to increasing levels of vibration. 


\subsection{Vibration Tests}

The shaker consists of random generators and hydraulic actuators which are capable of driving the shaker in three directions simultaneously. The shaker has the following limitation in each axis :

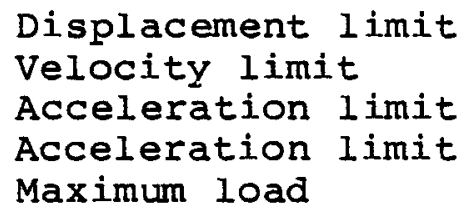

$152 \mathrm{~mm}$

$820 \mathrm{~m} / \mathrm{s}$

$4 \mathrm{~g}$ (no load)

$1.6 \mathrm{~g}$ (fully loaded)

$2000 \mathrm{~kg}$

Simultaneous random inputs were applied in three axes and the coherence between axes was negligible. The vibration levels in the two horizontal and vertical directions were individually controlled to nominally give similar levels. These levels were set by adjusting a "span" potentiometer. The span setting used is of no significance in itself except equivalent span settings nominally indicate equivalent vibration levels. The vibration is never the same from one test to the next since a different random signal is used for each test.

\subsection{RESULTS}

A test log (Table I) shows the sequence of testing for each cell. The cells did not show any signs of failure. The test response spectrums are given in Figures 2 through 25 . No electrical failures were observed.

\subsection{CONCLUSIONS}

The Exide cells have minimum ZPA values, as described in IEEE 501 and as shown in Table 2. These cells were well constructed and showed no signs of failure.

Approved :

\section{D.B. Craig}

Section Head

Mechanical Testing and

Development Section

Mechanical Research Dept

\section{Submitted :}

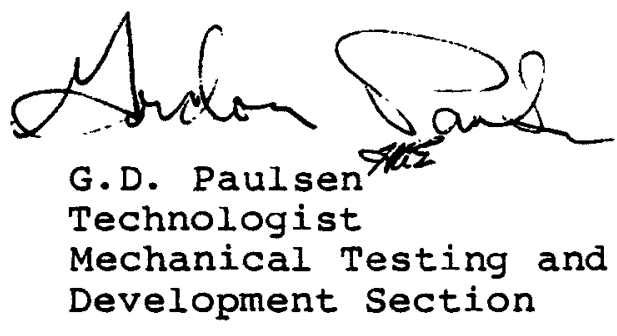

D.a. Blach

D.A. Black

Engineer

Mechanical Testing and

Development Section 


\section{REFERENCES}

1. The Institute of Electrical and Electronic Engineers Inc. IEEE 344. Qualification of Class $1 E$ Equipment for Nuclear Power Generating Stations. New York. 1975.

2. The Institute of Electrical and Electronic Engineers Inc. IEEE 501. IEEE Recommended Practices for seismic Qualification of Relays.

3. Harris, Cyril M., and Charles E. Crede. "Shock and Vibration Handbook". Second Edition. McGraw Hill Book Company. Toronto. 1976. 
TABLE I

TEST LOG OF SEISMIC TESTS ON EXIDE CELLS

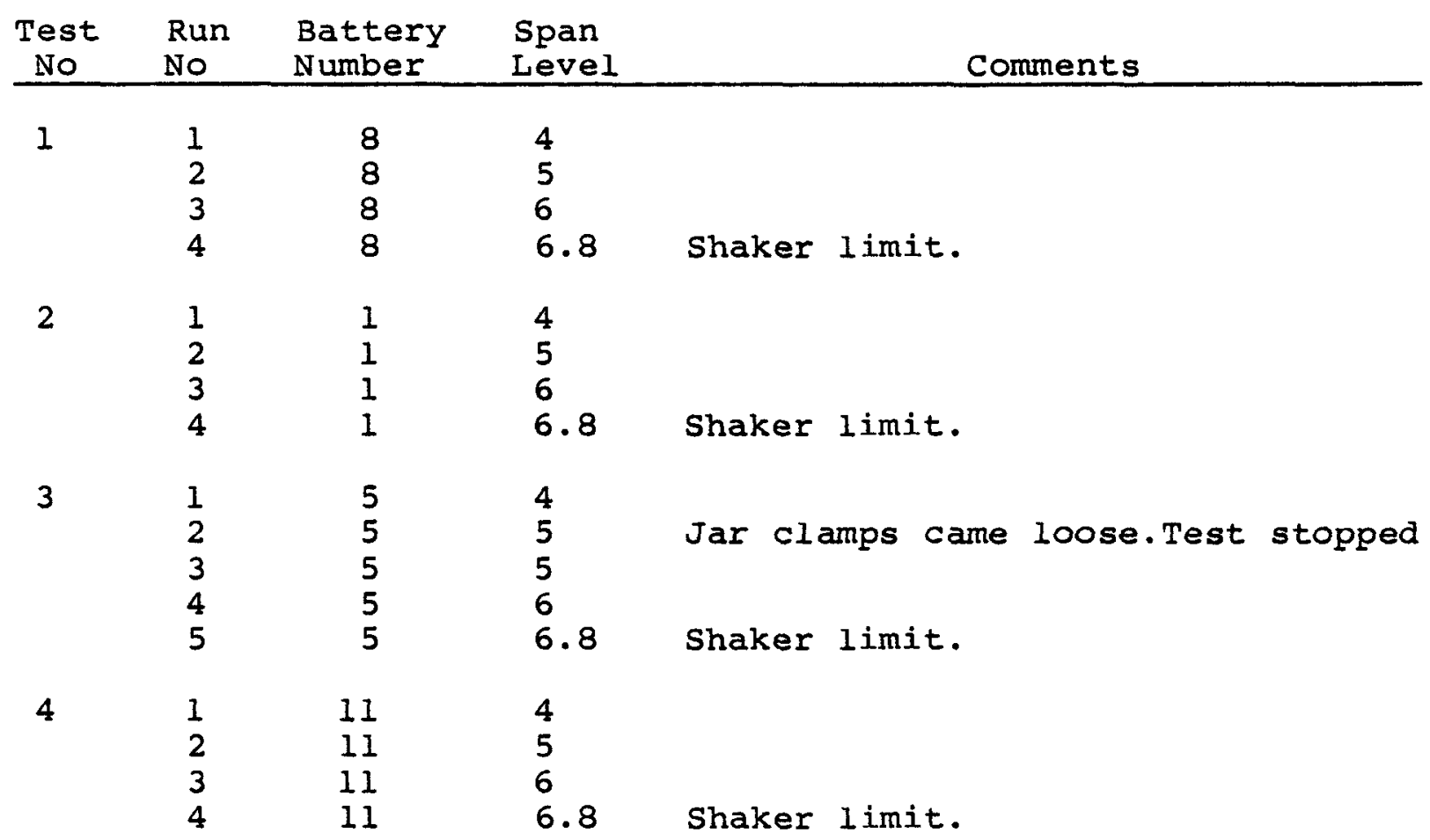


TABLE II

MINIMUM ZPA VALUES ( $\mathrm{g}$ )

Cell

Location

Direction

ZPA

8

base

base

base

terminal

terminal

terminal

$\mathrm{X}$

$Y$

Z

$\mathrm{X}$

$Y$

$\mathrm{Z}$

2.18

1.77

1.37

2.00

2.24

1.47

1

base

base

base

terminal

terminal

terminal

$\begin{array}{ll}\mathrm{X} & 1.83 \\ \mathrm{Y} & 1.56 \\ \mathrm{Z} & 1.47 \\ \mathrm{X} & 1.84 \\ \mathrm{Y} & 2.00 \\ \mathrm{Z} & 1.63\end{array}$

5

base

base

base

terminal

terminal

terminal

1.65

1.50

1.50

1.65

1.54

2.61

11

base

base

base

terminal

terminal

terminal

2.16

1.59

1.63

1.85

2.00

1.56 

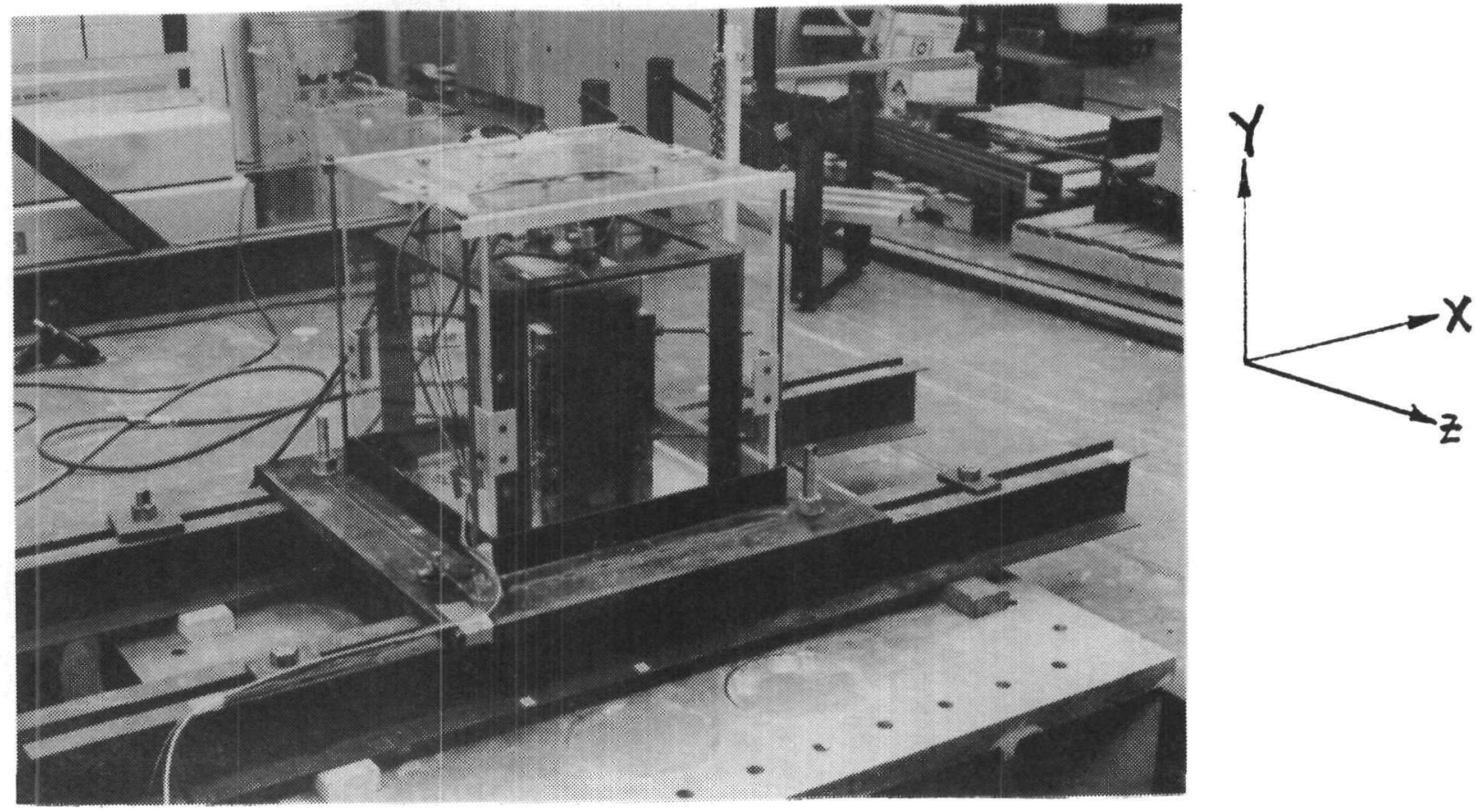

FIGURE 1

TYPICAL MOUNTING OF EXIDE CELL IN SINGLE CELL RIGID FRAME, WOOD SPACERS WERE REQUIRED FOR THIS CELL, THE CELL IS CLAMPED AT THE FOUR CORNERS USING THREADED RODS, ACCELEROMETERS WERE MOUNTED AT THE BASE AND ONE OF THE TERMINAL POSTS, THE AXES OF VIBRATION ARE INDICATED. 


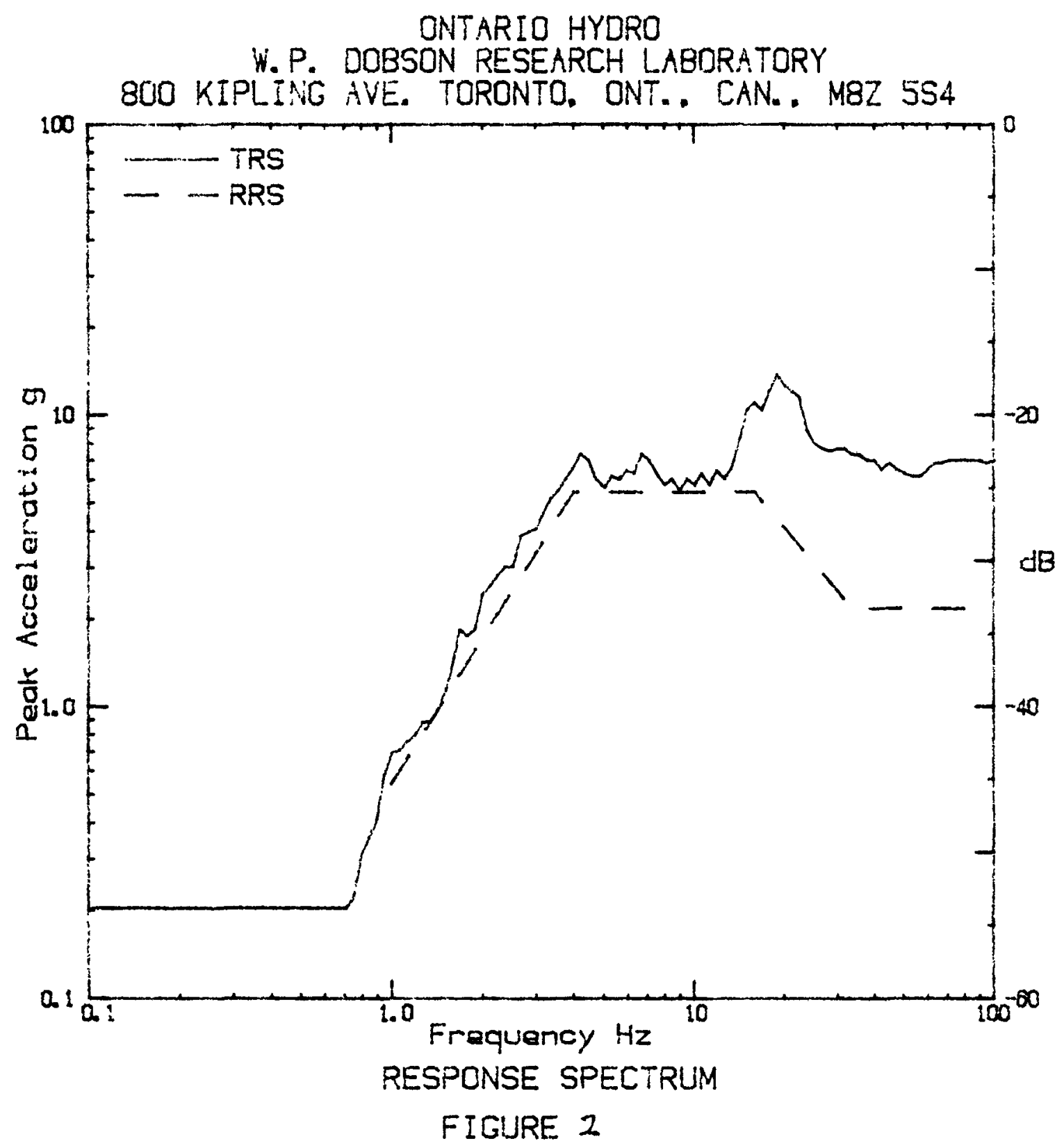

TEST ITEM

Station cells. Exide Madal EMP 13. Sartal 8,

PARTICULARS

March 14,94. Time 11:28. Tamp('O) 23. Humidity(*) 39.

Press (tePa) iDo. 2. Grapi 5110

SPECIFICATIONS

Specs IEEE 501. Conditions span 6.8, voltage \& current monitorad

ANALYSIS

Type Meximex, Domping (j) 5. B. W. = 1/12 Octoves, Axis X

Shaker tri-tixial. ZPX. $=2.18 \mathrm{~g}$

ACCELERDMETER

Wilcoxon. Serial 5757. Range dB58. Lacation basa-mounting jig.

TI 702. Channel 1 
W.P. DOBSON RESEARCH LABORATORY

BOO KIPLING AVE. TORONTO. ONT.. CAN., M8Z $5 S 4$

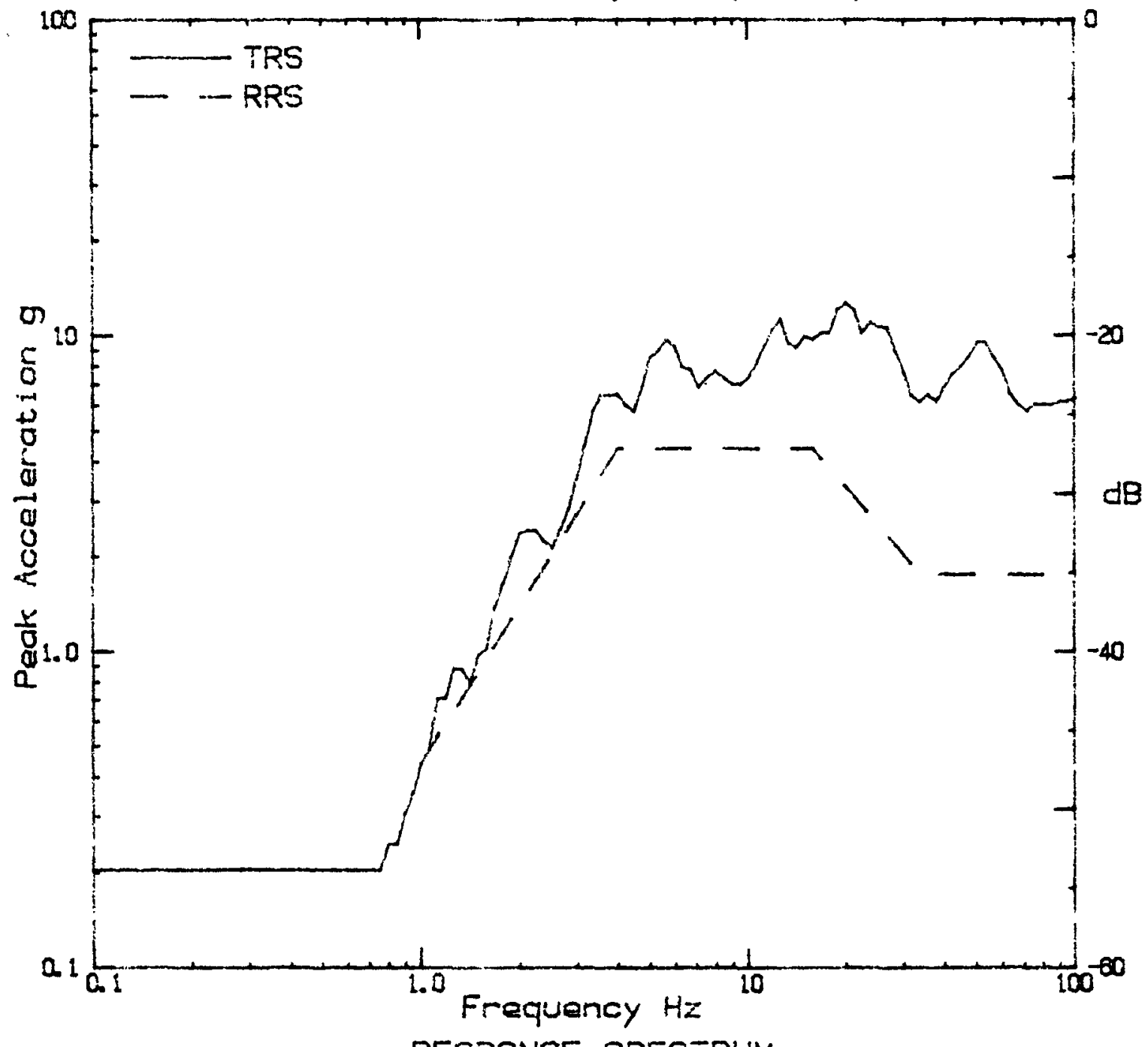

RESPDNSE SPECTRUM

FIGURE 3

TEST ITEM

Station celis. Exide. Madel EMP 13. Soria! 8.

PARTICULARS

March 14/84. Time 1i:28. Temp ('C) 23. Humidity (z) 39.

Press (KPa) loc. 2. Graph 5111

SPECIFICATIONS

Spece IEEE 50i. Conditions span 6.8, voltage \& current monitored

ANALYSIS

Type Maximax. Damping (\%5, B. W. = $1 / 12$ Datoves, Axis Y, Shaker tri-axial, $Z P A=1.77 \mathrm{~g}$

ACCELEROMETER

Wilcoxon. Serial 576i, Range dB58. Location bose-meunting jig. TT 702. Channel 2 
ONTARIO HYDRO

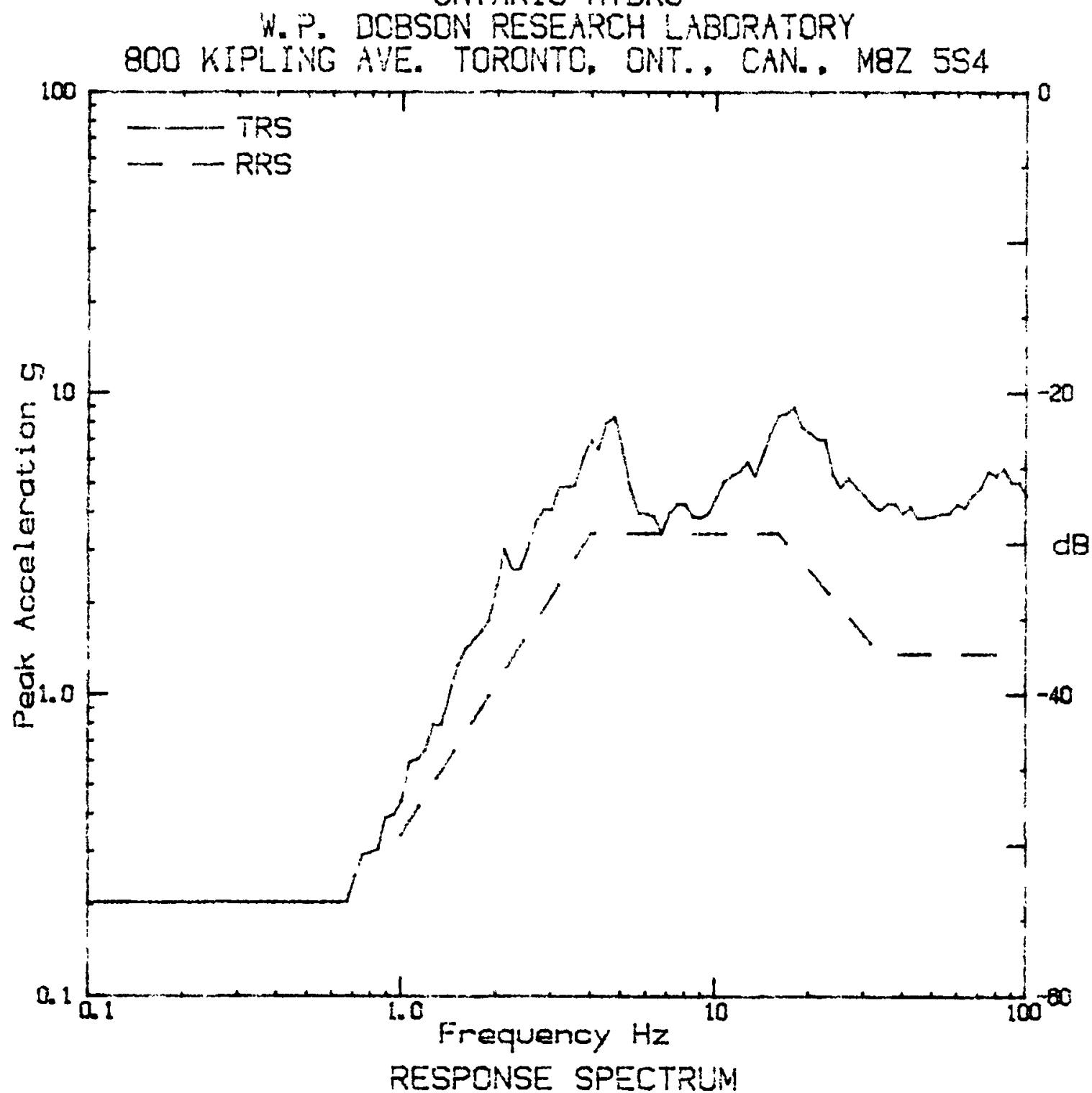

FIGURE 4

\section{TEST ITEM}

Station cails. Exide Madal EMP 13. Sarial 8.

PARTICULARS

March 14/84. Time 1L:28. jimp('C) 23. Humidity(5) 39.

Press (kPo) ido. 2. Groph 5112

SPECIFICATIONS

Specs IEEE 501, Conditions span 6.8, voltage \& current monitored

ANALYSIS

Type Maximax, Damping (z)S, B. Shaker tri- $-X X_{i}$ al. $Z P X=1$. $37 \mathrm{G}$

ACCELEROMETER

Wiicoxon. Seriui 5901. Range desa. Location bose-mounting jig. 


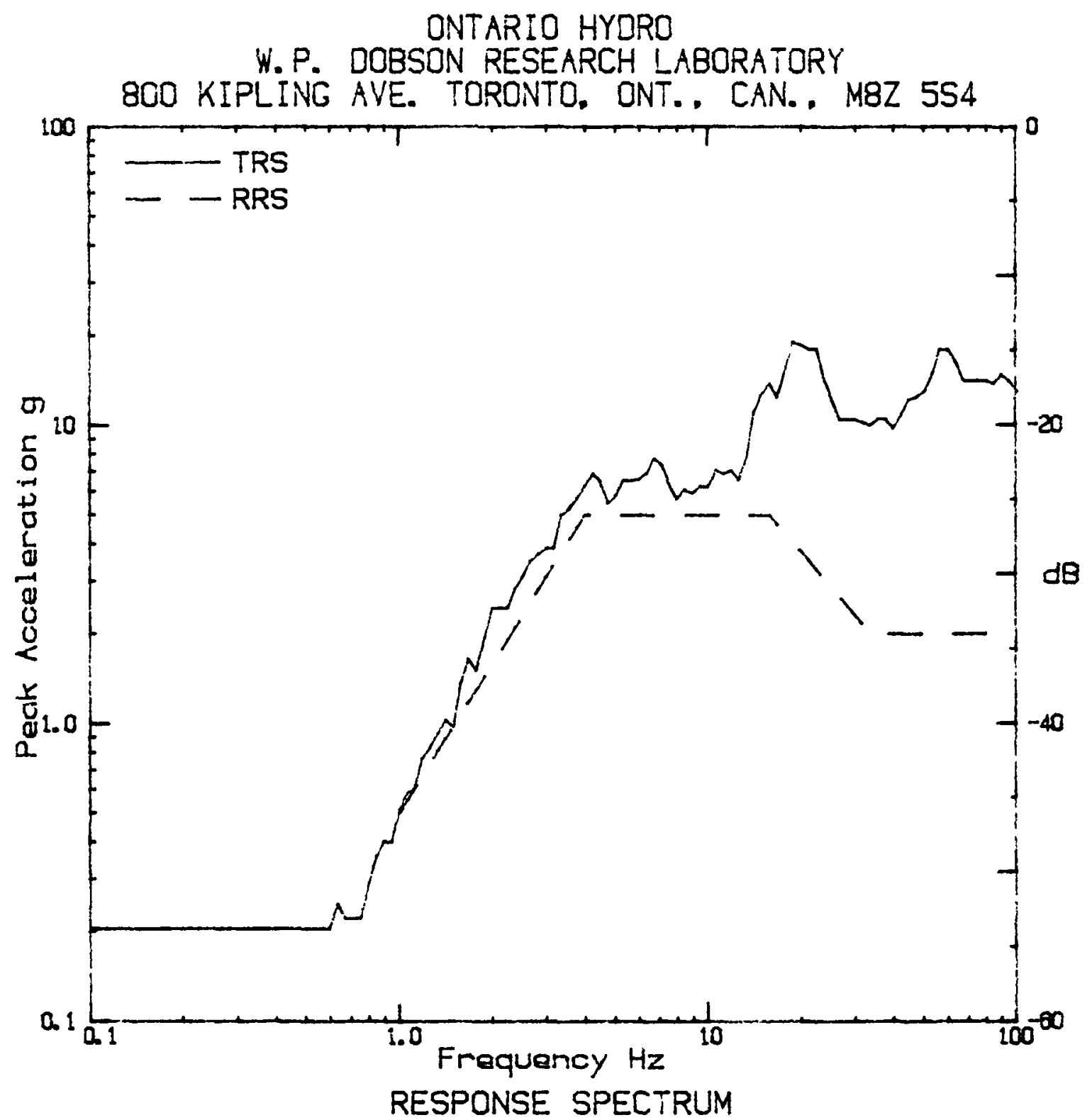

FICURE 5

\section{TEST ITEM}

Station cells. Exida Model EMP 13. Sorial 8.

PARTICULARS

March 14,84, Jime 11,28, Temp('C) 23. Humidity( $\left.{ }^{\prime}\right) 39$.

Press ( $k P a)$ ioo. 2. Graph $5113^{\circ}$

SPECIFICATIONS

Specs IEEE 501. Conditions span 6.8, voltage \& current monitored

ANALYSIS

Type Maximcx. Damping (\%) 5. B. W. $=1 / 12$ Octaves, Axis $X_{0}$ Shaker tri-axial. ZPX $=2 g$

ACCELERDMETER

Wilcoxon. Serial 5771. Range dB58. Location top-celi terminal. TT 702. Channel 4 


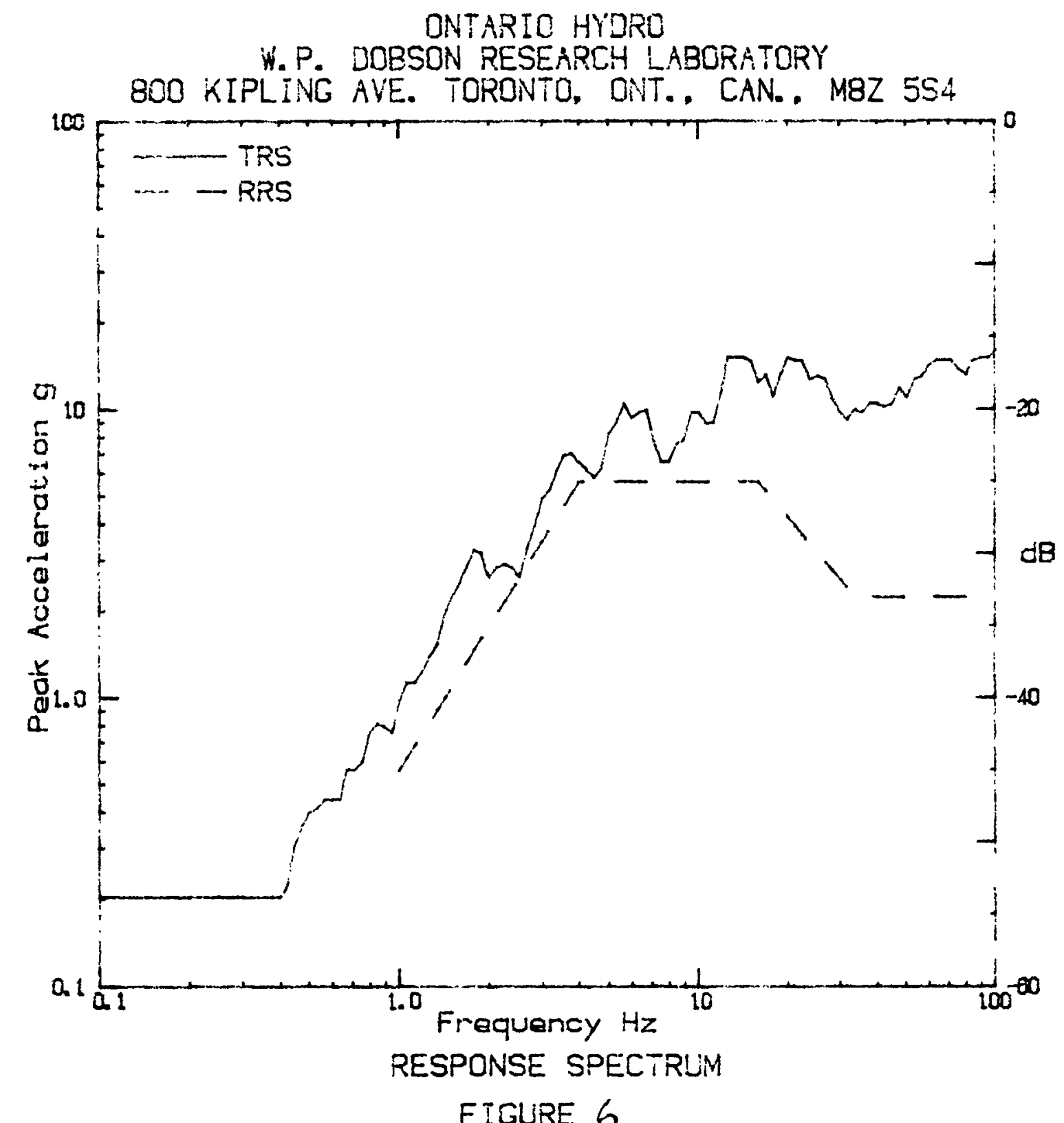

TEST ITEM

Stotion calls. Exida Model EMP 13. Serici a.

PARTICULARS

March 14/84. Time 11:28. Temp('C) 23. Humidity (\%) 39 .

Press (kPa) 100.2. Graph 51 iद

SPECIFICATIONS

Specs IEEE 50i. Conditions span 6.8, valtage \& eurrent monitored

ANALISIS

Type Kaximax. Damping (a) 5. B. $W_{0}=1 / 12$ Cctaves. Axis $Y_{0}$ Shaker tri-axial. $7 P k=2.24 \mathrm{G}$

ACCELEROMETER

Wícoxon, Seriol S297. Range dB58. Location top-cell terminal. TT 7C2. Channel 5 


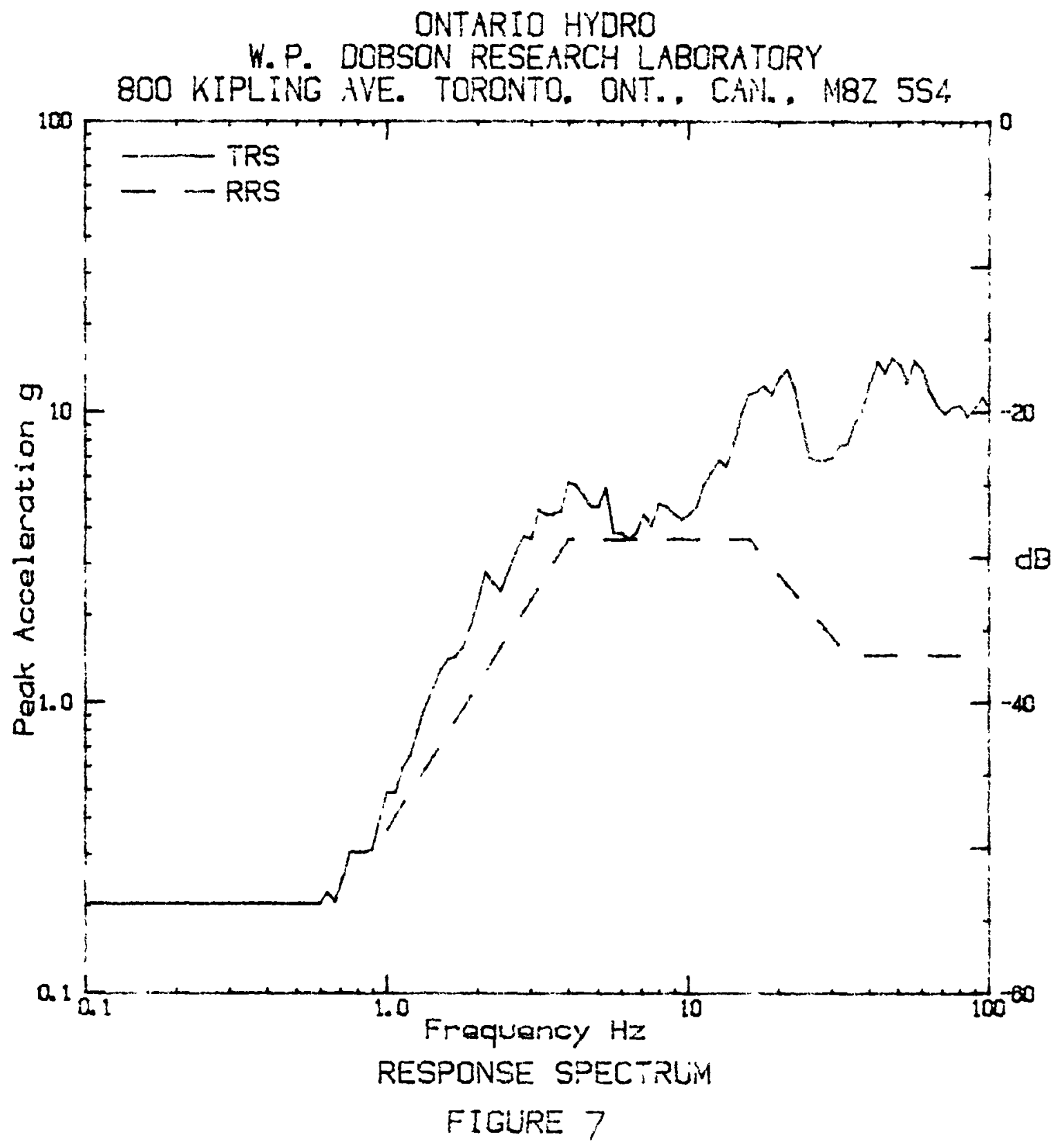

TEST ITEM

Station cells, Exide. Modal FMP 13. Seria: 8

PARTICULARS

March 14/84. Time 11:28. Temp('O) 23. Humidity(\%) 39.

Press (itPo) 100. 2. Graph 5115

SPECIFICATIONS

Specs IEEE 5Ci. Conditions span 0.8 , voltage \& current monitored

ANALYSIS

iype Maxima: Damping (\%) 5. 3.W. $=1 / 12$ Octoves, Axis Z. Shaker tri-axial. $Z P X=1.47 \mathrm{~g}$

ACCELEROMETER

Wilcoxon. Serial 5754, Range dB58, Locction top-cell terminul.

TT 702. Channe: 6 
W.P. DCBSON RESEARCH LABCRATORY

800 KIPLING AVE. TORONTO. ONT., CAN., MBZ SS:

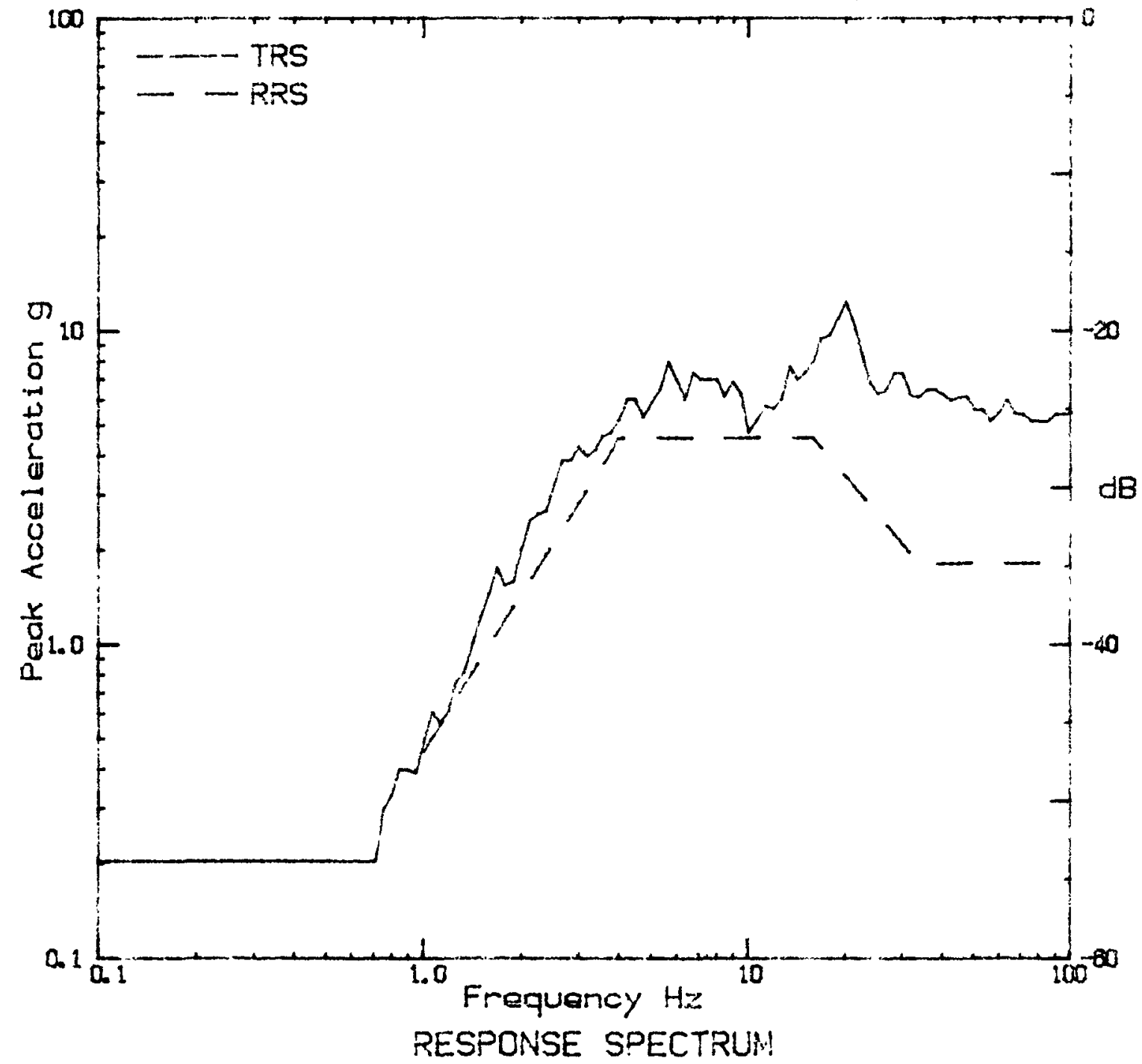

FIGURE 8

TEST ITEM

Station calis. Exida. Modal EMP 13. Sericl 1

PARTICULARS

March 14/84. Time 1: 45. Tamp('C) 23. Humidity(\%) 39.

Press (kPa) 100.2. Graph 5116

SPECIFICATIONS

Specs IEEE 501. Conditions span 6.8, yoltage \& currant monitorad

ANALYSIS

Type Haximax, Demping (\%) 5, B. W. = 1/12 Cctaves, Axis $X_{0}$ Shaker tri-cxial. ZPX $=1.83 \mathrm{~g}$

ACCELERGMETER

Wilcoxon. Sarial 5757. Range dB58, Location base-mounting jig. TT 710, Channel 1 


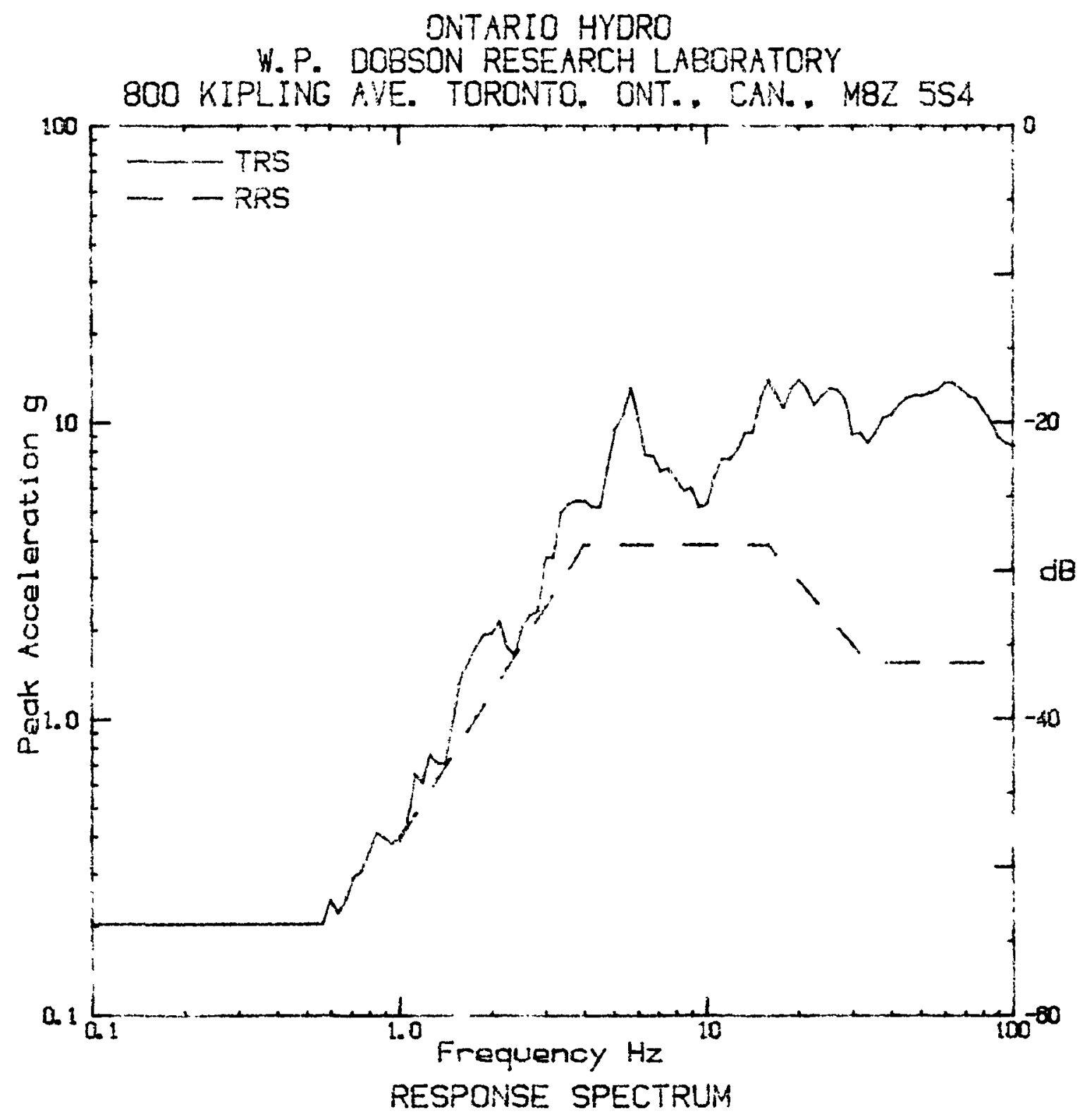

FIGURE 9

TEST ITEM

Station calls. Exida, Modal EMP 13. Sarial 1

PARTICULARS

March 14,84. Time 1:45. Temp('C) 23. Humidity(\$) 39.

Prass (KPa) 100. 2. Graph 5117

SPECIFICATIONS

Specs IEEE 501. Conditions span 6. 8, voltage \& current monitored

ANALYSIS

Type Maximax. Damping (\%) B. B. $\psi_{0}=1 / 12$ Dctaves, Axis $\%$

Shaker tri-axial. ZPX $=1.56 \mathrm{~g}$

ACCELEROMETER

Wilcoxen, Serial 5761. Range dB58, Location bcse-mounting jig. TT 710. Channel 2 


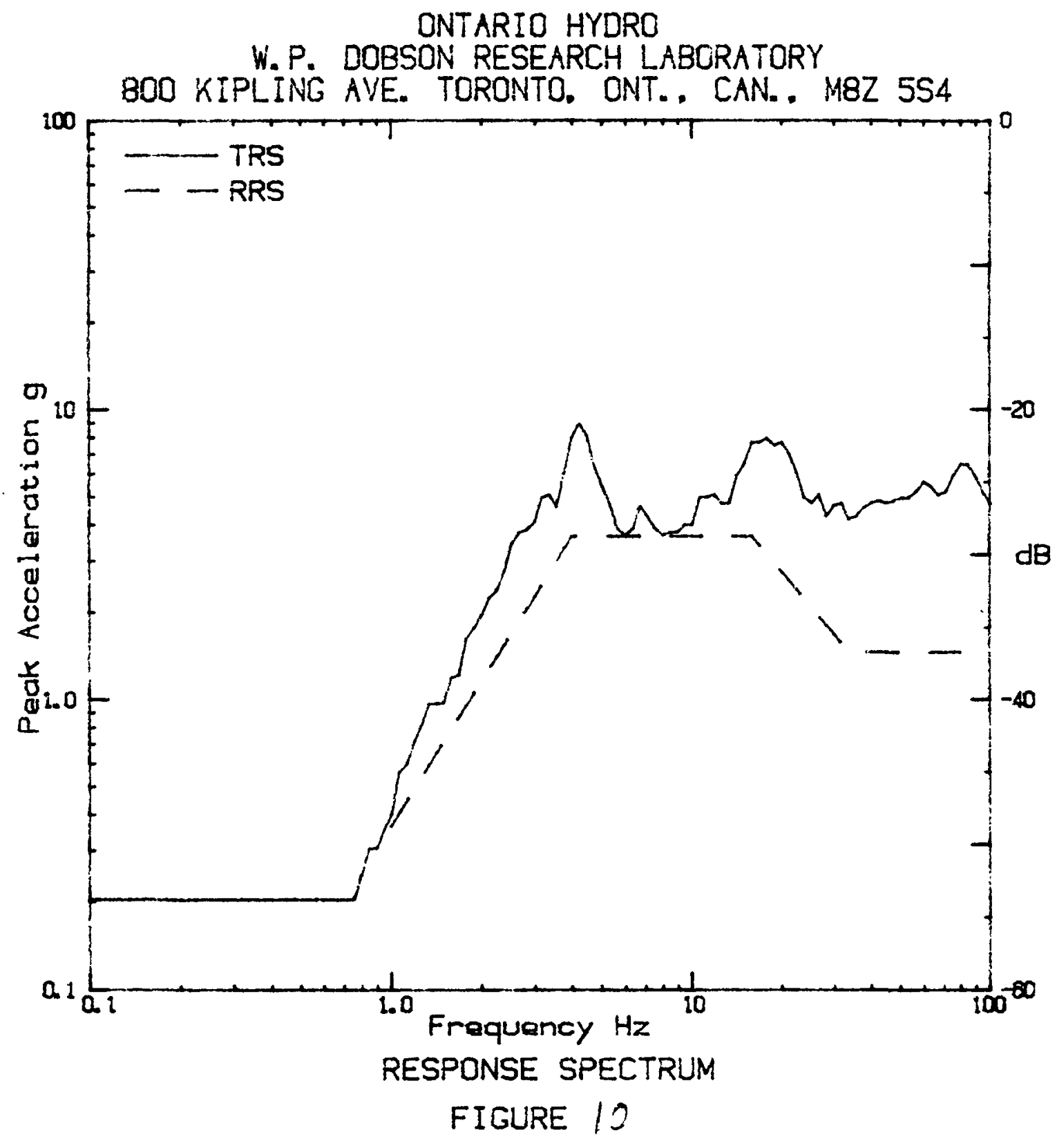

TEST ITEM

Station ceila, Exida Modal EMP 13. Serial 1

PARTICULARS

March 14/84, Time 1:45. Temp ('C) 23. Humidity( 7$)^{\prime}$ 39,

Prass (kPa) 100. 2. Graph 5118

SPECIFICATIONS

Spece IEEE 501. Conditions span 6.8, voltage 8 current monitorad

ANALYSIS

Type Maximax, Damping (2) 5. B. $W_{0}=1 / 12$ Dctaves, Axis Z.

Shaker tri-axial. $Z P X=1.47 \mathrm{~g}$

ACCELEROMETER

Wilcoxon, Serial S901, Range dB58, Location base-mounting jig.

TT 710. Channel 3 


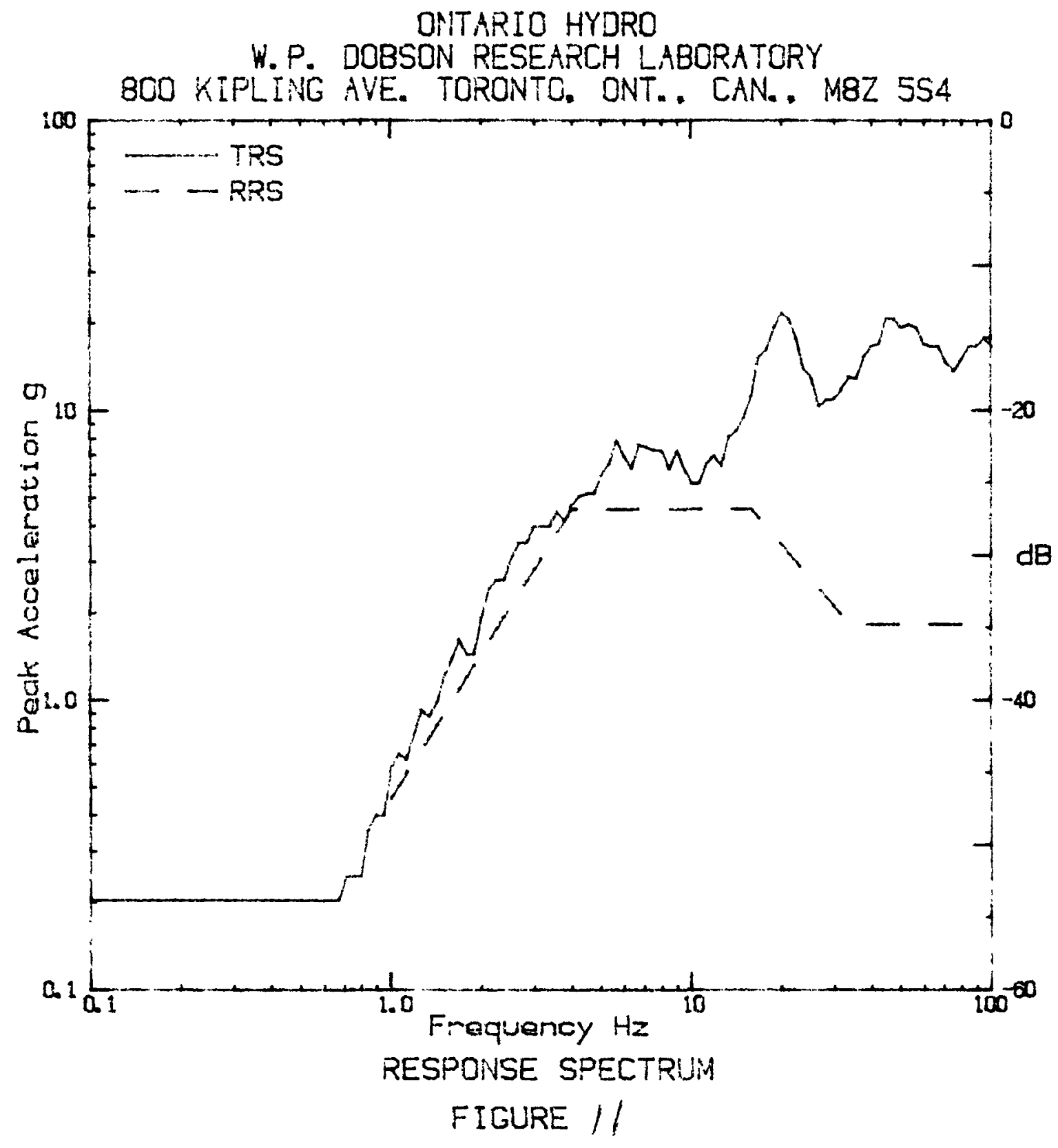

TEST ITEM

Station calis, Exide. Modal EMP 13. Serial 1

PARTICULARS

March 14/84. Time 1: 45. Temp ('C) 23. Humidity(z) 39.

Prass (kPO) 100.2. Graph 51 is

SPECIFICATIONS

Specs IEEE 501. Conditions span 6.8, voltage \& currant monitored

ANALYSIS

Type Maxinax. Damping (t) 5. B. $\psi_{0}=1 / 12$ Dctoves, Axis $X$

Shaker tri-axicl. $Z P X=1.84 \mathrm{~g}$

ACCELEROMETER

Wilcoxon. Serial 5771. Range dB58. Location top-cell terminal,

TT 710. Channel 4 


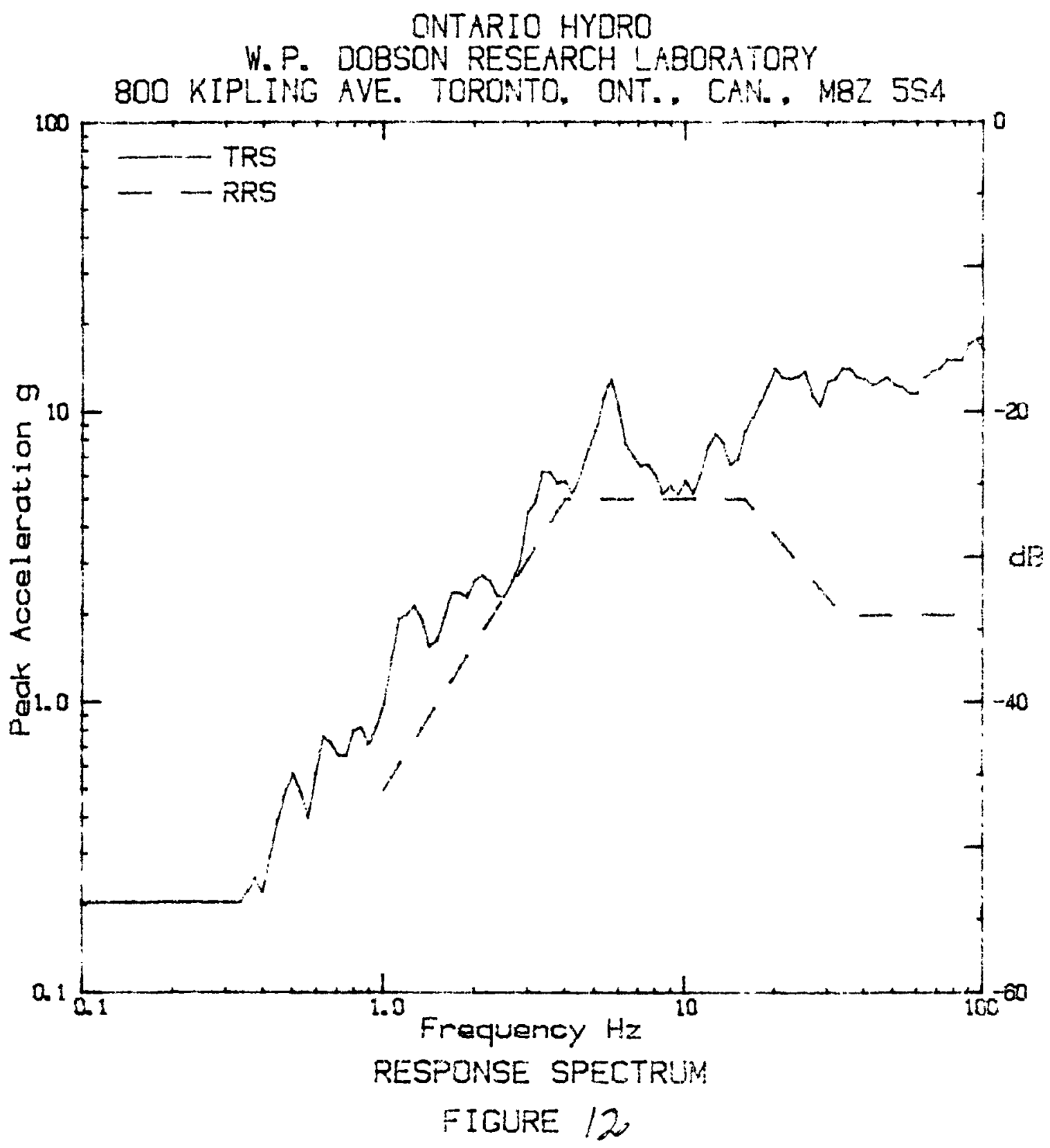

TEST ITEM

Station cells. Exida, Madal EMP i3. Serial 1

PARTICULARS

March 14/94. Time 1: 45. Tamp('C) 23. Humidity( $(z) 39$.

Press (kPa) ico.2. Graph 5120

SPECIFICATIONS

Specs IEEE 501. Conditions spen 6.8, voltage 3 current monitored

ANALYSIS

Type Maximax. Damping (z) 5, B. $k_{-}=1 / 12$ Dctaves, hxis $Y$. Shaker tri-axiel. $Z P A=2 g$

ACCEL.ERDMETER

Wilcoxon. Sorial S297. Range dB5e. Location top-cell terminal. TT ?10. Chonnel 5 
CNTARIO HYORO

W. P. JOBSON RESEARCH LABORATORY

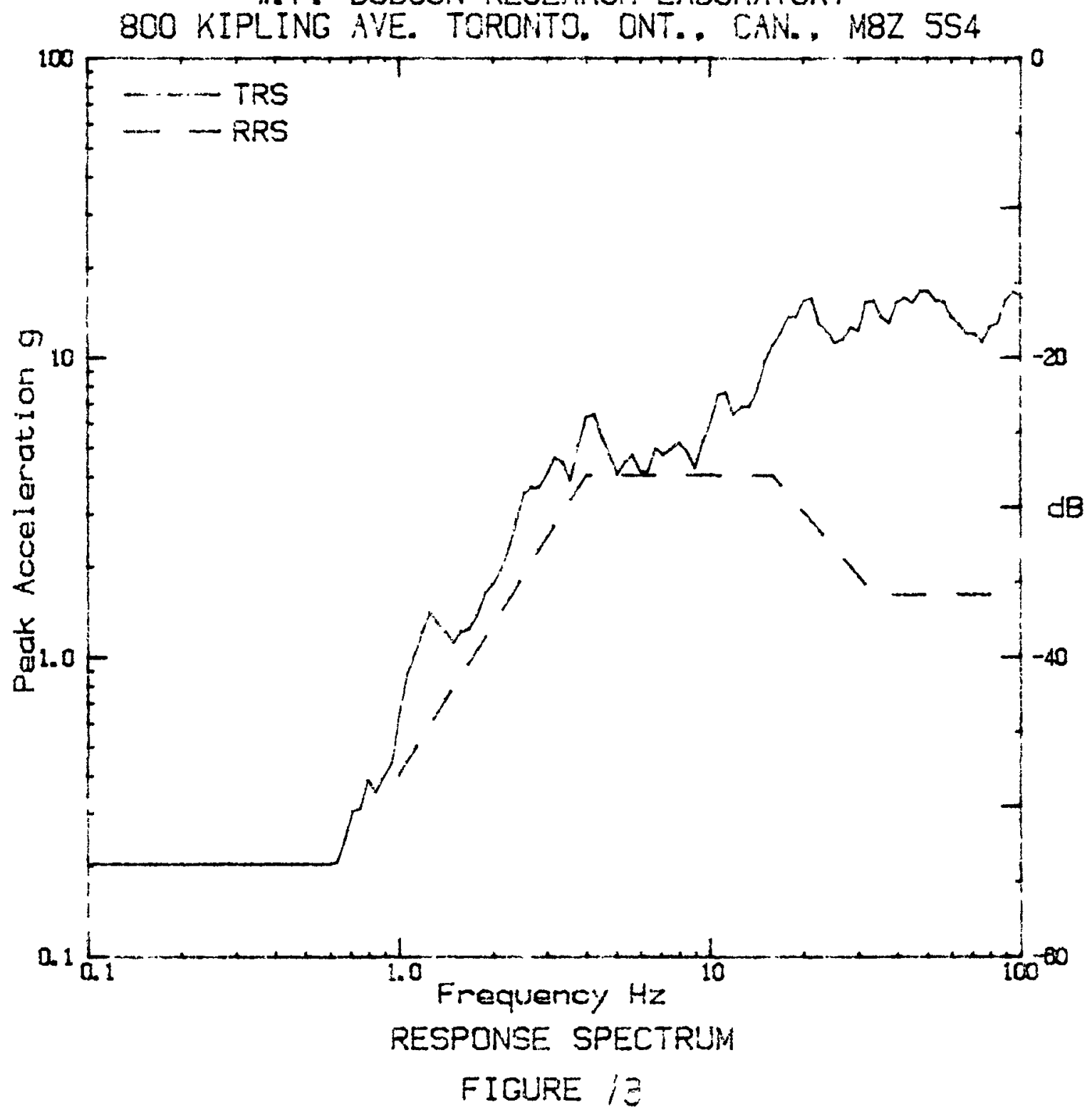

TEST ITEM

Station cellis, Exide Modal EMP 13. Sarial 1

PARTICUI-ARS

March 14,84. Time 1: 45. Tamp ('C) 23, Humidity (") 39 .

Press (KPo) i00. 2. Graph 5121

SPECIFICATIDNS

Specs IEEE 501. Conditions spen 6.8, voltage \& current nonitored

ANALYSIS

Type Maximax. Damping (ّ) 5. B. W. $=1 / 12$ Octcres, Axis Z. Shaker tri-oxial. $Z P X_{i}=1$. $63 \mathrm{~g}$

ACCELEROMETER

Wi Lcoxon. Serial 5754, Renge dP5B. Location top-celi terminai. $T T$ 710. Channel 6 
DNTARID HYDRO

W. P. DOBSON RESEARCH LABORATORY

800 KIPILING AVE. TORONTO, ONT. . CAN. . M8Z 554

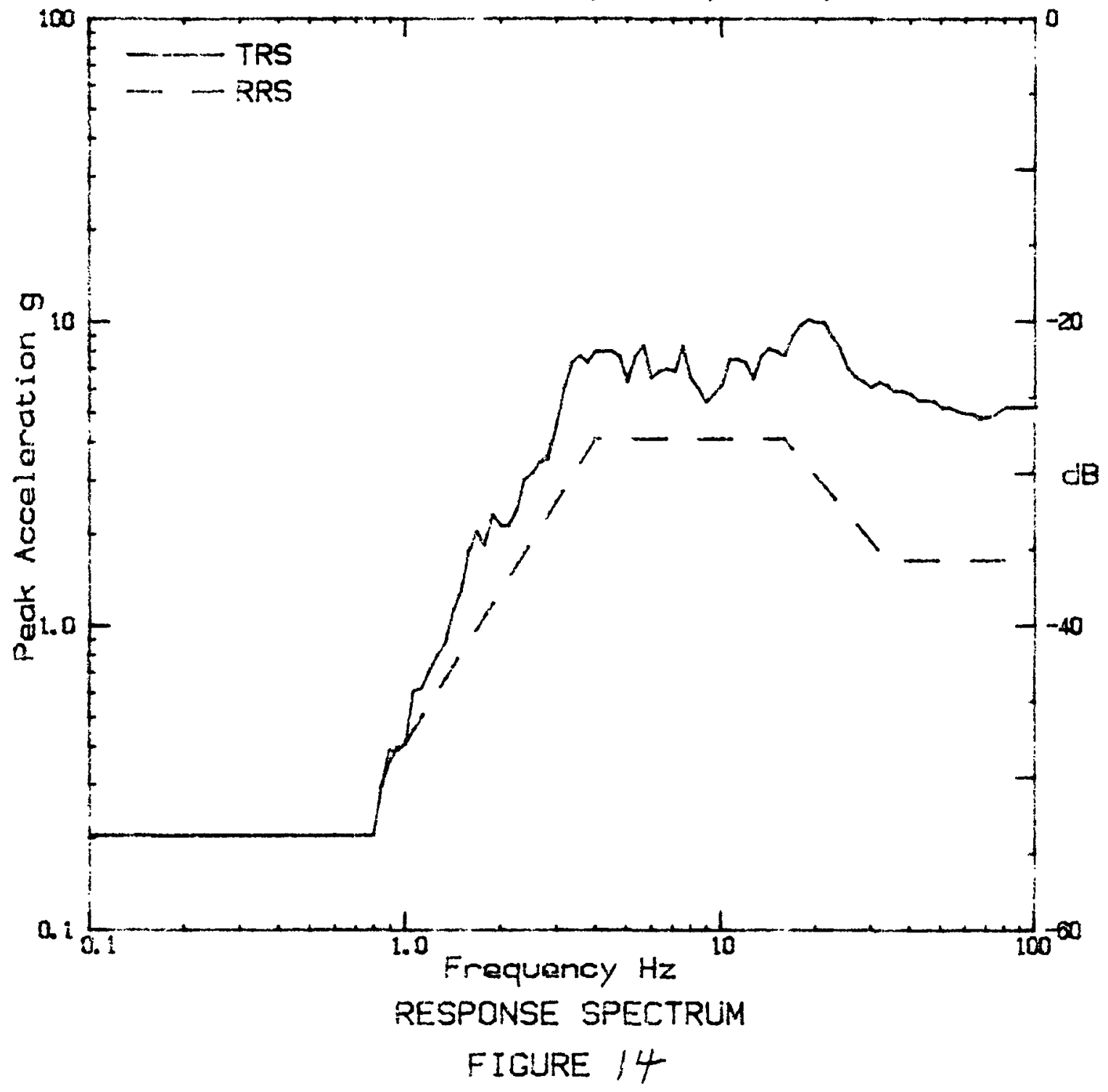

TEST ITEM

Stotion cells. Exide, Modal EMP 13. Serial 5.

PARTICUIAARS

Mareh 14/84. Time 2: 35. Tamp('C) 23. Humidity ( $(0)$ 39,

Press (kPa) 100.2. Giecph 5122

SPECIFICATIONS

Specs IEEE 501. Conditions spon 6.8, voltage \& current monitored ANALYSIS

Type Maximax. Damping (z) 5. B. W. = 1/12 Detavas, Axis X. Shoker E-i-cxial. $Z P X=1.65 \mathrm{~g}$

ACCELERROMETER

Wilcoxon. Serial S757. Range dB58. Location boee-mounting jig. 


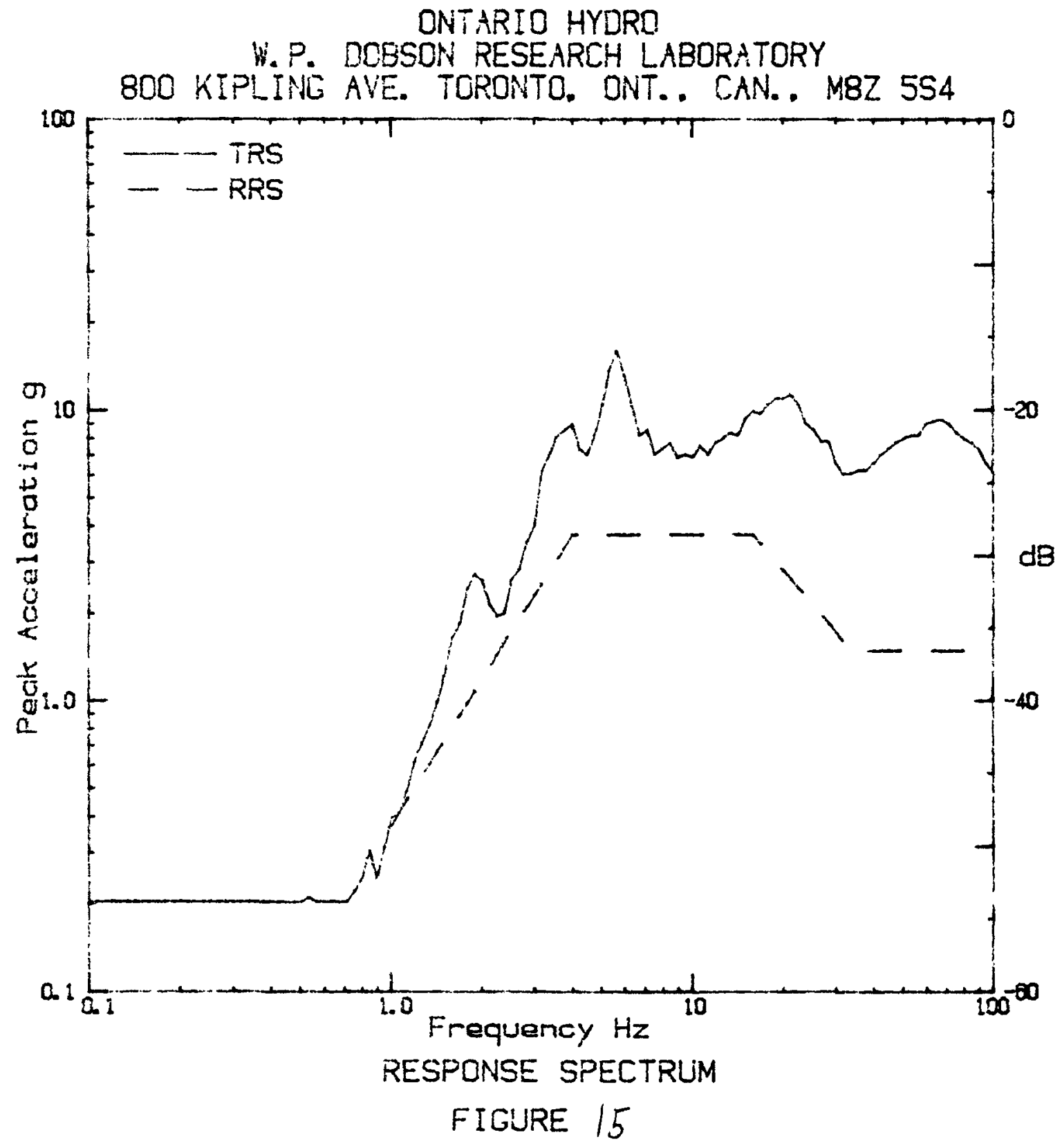

TEST ITEM

Stotion cells, Exide. Modal EMP 13. Serial 5.

PARTICULARS

March 14/84. Time 23 35. Temo ('C) 23. Humidity $(x) 39$.

Prass (KPa):00.2. Graph 5123

SPECIFICATIONS

Specs IEEE 501. Conditions span 5.8, voltage \& aurrent monitored

ANALYYSIS

Type Maximox. Damping (\%) 5. B.W. $=1 / 12$ Detaves. Aris $Y_{\text {. }}$ Shaker tri-axial. $Z P K=1.5 \mathrm{~g}$

ACCELEROMETER

Wilcoxon. Serial S761. Range dBS8. Location basemounting jig.

TT 720. Channel 2 


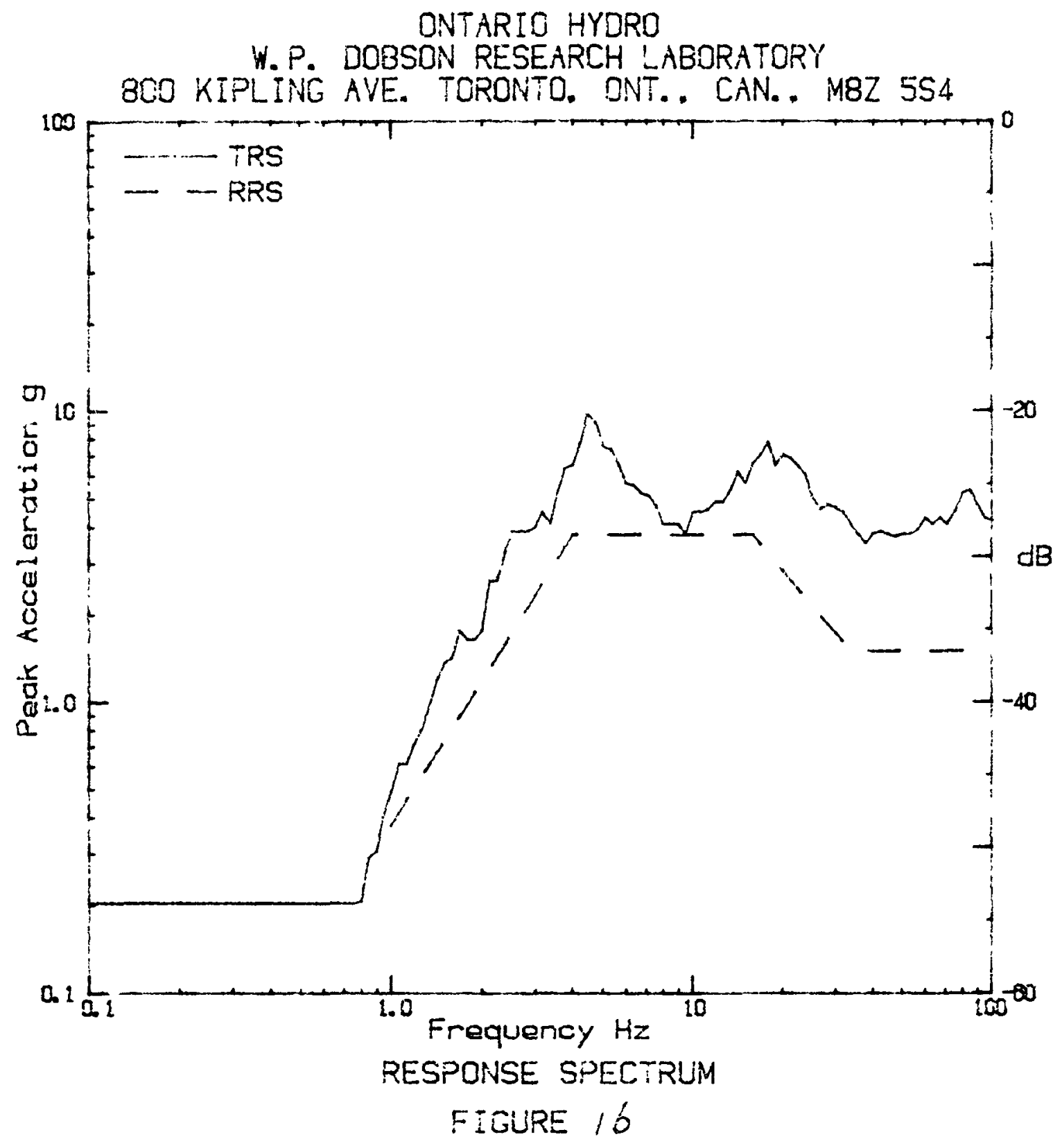

TEST ITEM

Station cells. Exida. ilodel EMP 13, Serial 5.

PARTICULARS

March 14/84. Time 2: 35. Temp $\langle ' C\rangle$ 23. Humidity (\$) 39.

Press (KPa) 100. 2. Graph 5124

SPECIFICATIONS

Specs IEEE 501. Conditions span 5.8. voltage \& current monitored

ANALYSIS

Type Maximax. Domping (\%) 5. B. $H_{0}=1 / 12$ Gotoves, Axis Z.

Shoker tri-axial. $Z P x_{n=1.5 \mathrm{~g}}$

ACCELEROMETER

Wilcoxen. Serial S901. Range dB58. Lecction bose-mounting jig. 


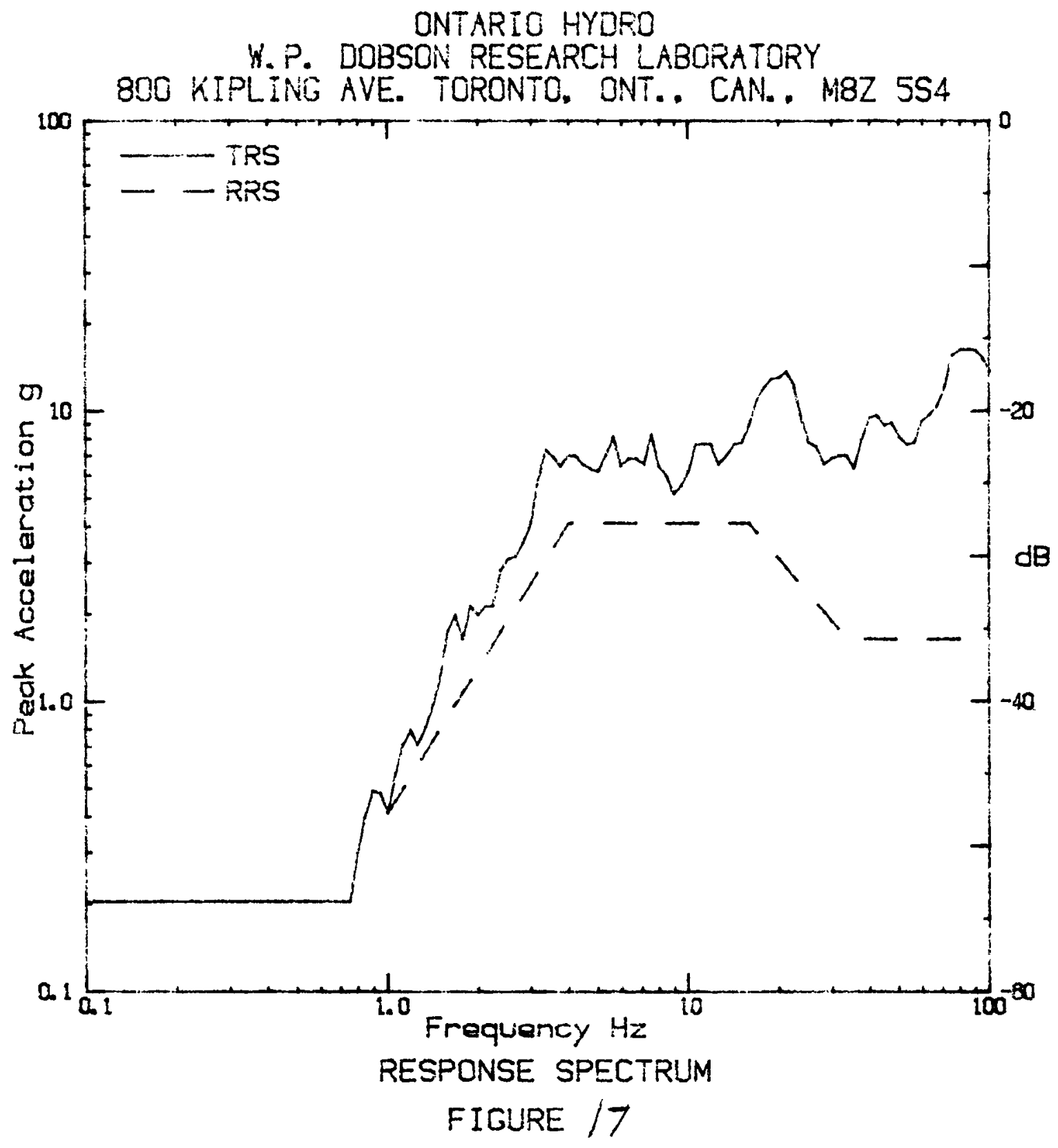

TEST ITEM

Station calls, Exida. Madal EMP 13. Serial 5.

PARTICULARS

March 14,84. Time 2: 35. Temp'('C) 23. Humidity( $\%$ ) 39.

Press (kPa) 100.2. Graph 5125

SPECIFICATIONS

Specs IEEE 501, Conditions span 6.8, voltage \& current monitored ANALYSIS

Type Maximax. Damping (2) 5. B. $W_{0}=2 / 12$ Detcoves, Axis $X_{0}$ Shaker tri-axial. ZPR=1.65g

ACCELEROMETER

Yilcoxono Seriol S771. Range d858. Location top-cell terminal. TT ?20. Channel 4 


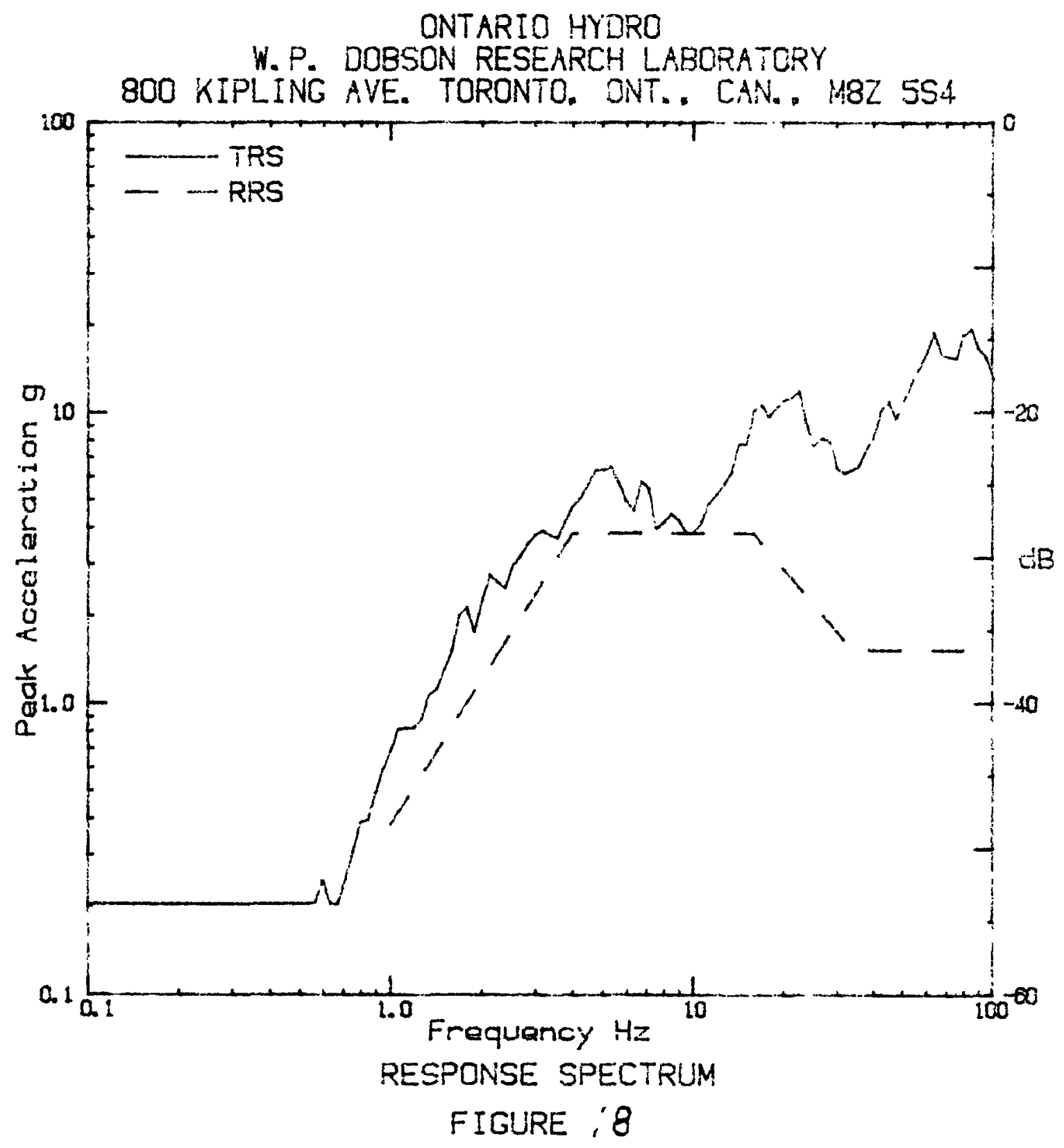

TEST ITEM

Station celis. Exide. Model EMP 13. Sarial 5.

PARTICULARS

March i4/84, Time 2:35. Temp('C) 23. Humidity(O) 39.

Press (KPa) 100. 2. Graph 5126

SPECIFICATIONS

Specs IEEE 501. Conditions span 6.8, vol toge a current menitorad

ANALYSIS

Type Maximax, Damping (I) 5, B. $W_{0}=1 / 12$ Dctaves, Axis $Y_{0}$

Shaker tri-axial. ZPX $=1.54 \mathrm{~g}$

ACCELEROMETER

Wilcoxan Serial S29?. Range d858. Location top-cell termincl.

Ti 720. Channel 5 
ONTARIO HYORO

'.. P. DOBSON RESEARCH LABORATORY

800 KIPLING AVE. TORONTO. ONT. . CAN. . M8Z 554

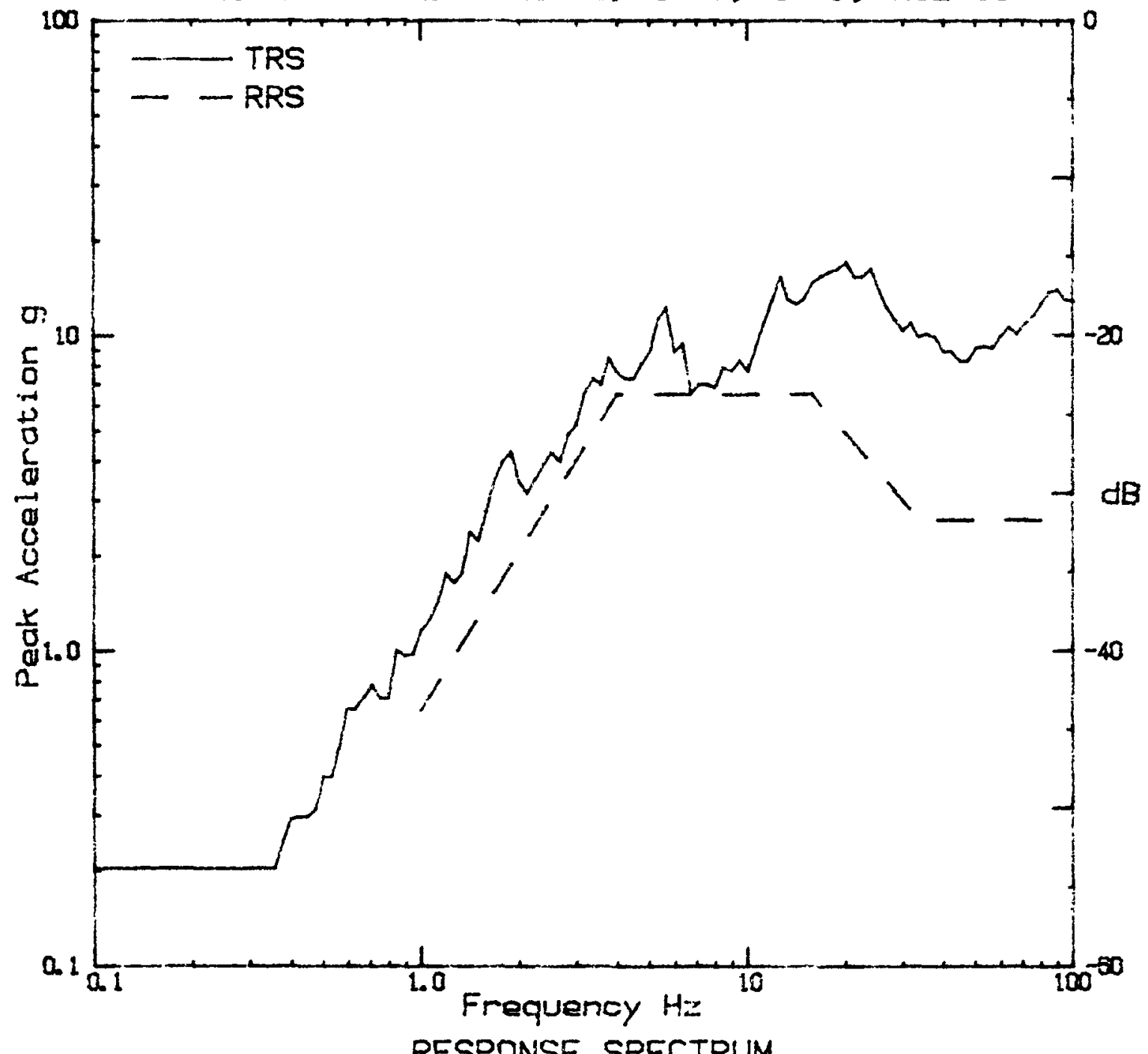

RESPONSE SPECTRUM

FIGURE 19

TEST ITEM

Station cells. Exide. Model EMP 13. Serial 5.

PARTICULARS

March 14/84, Time 23 35. Tamp('C) 23. Humidity(x) 39.

Press (KPa) i00. 2. Graph 5127

SPECIFICATIONS

Specs IEEE 501. Conditions span 6.8. voltage \& current monitored

ANALYSIS

Type Maximax. Damping (x) 5. B. W. $=1 / 12$ Detayes. Axis Z. Shaker tri-axial. $Z P A=2$ 61g

ACCELEROMETER

Wilcoxon. Sorial S754. Range dB58. Location top-cell terminal. TT 720. Channel 6 


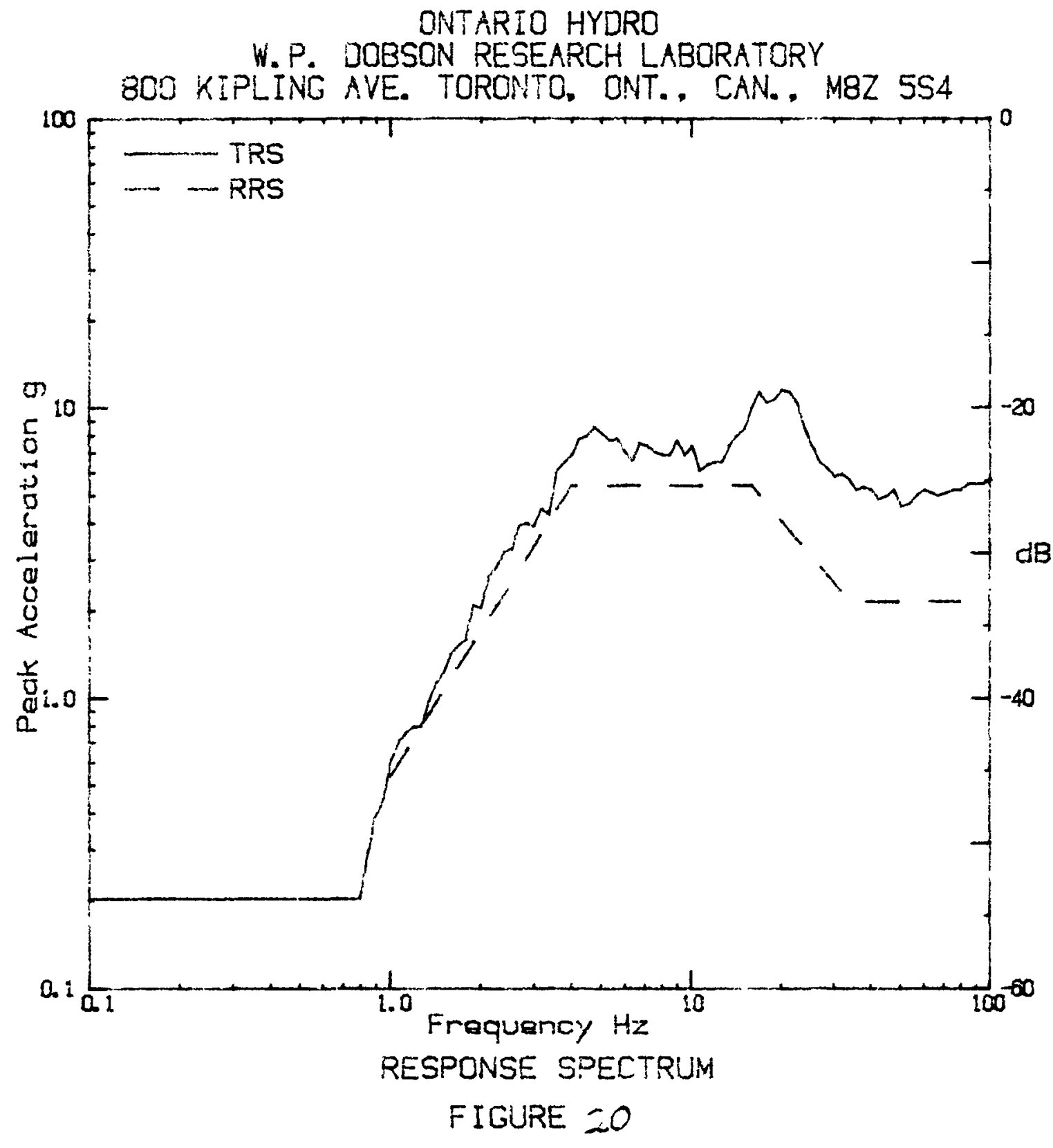

TEST ITEM

Station cells. Exida. Modal EMP 13. Sarial 11.

PARTICULARS

March 14/84, Time 3:00. Temp ('C) 23. Humidity ( $(y)$ 39.

Press (kPa) 100. 2. Graph 5128

SPECIFICATIONS

Specs IEtEE 501. Conditions span E.8. voltage \& current monitored

ANAL_YSIS

Type Maximax, Damping (\%) 5, B. $\%_{0}=1 / 12$ Dctaves, Axis X.

Shaker tri-axial, ZPXE2.159

ACCELERDMETER

Wilcoxon. Serial S757. Range dB58. Location base-mounting jig.

iT 730. Channel 1 


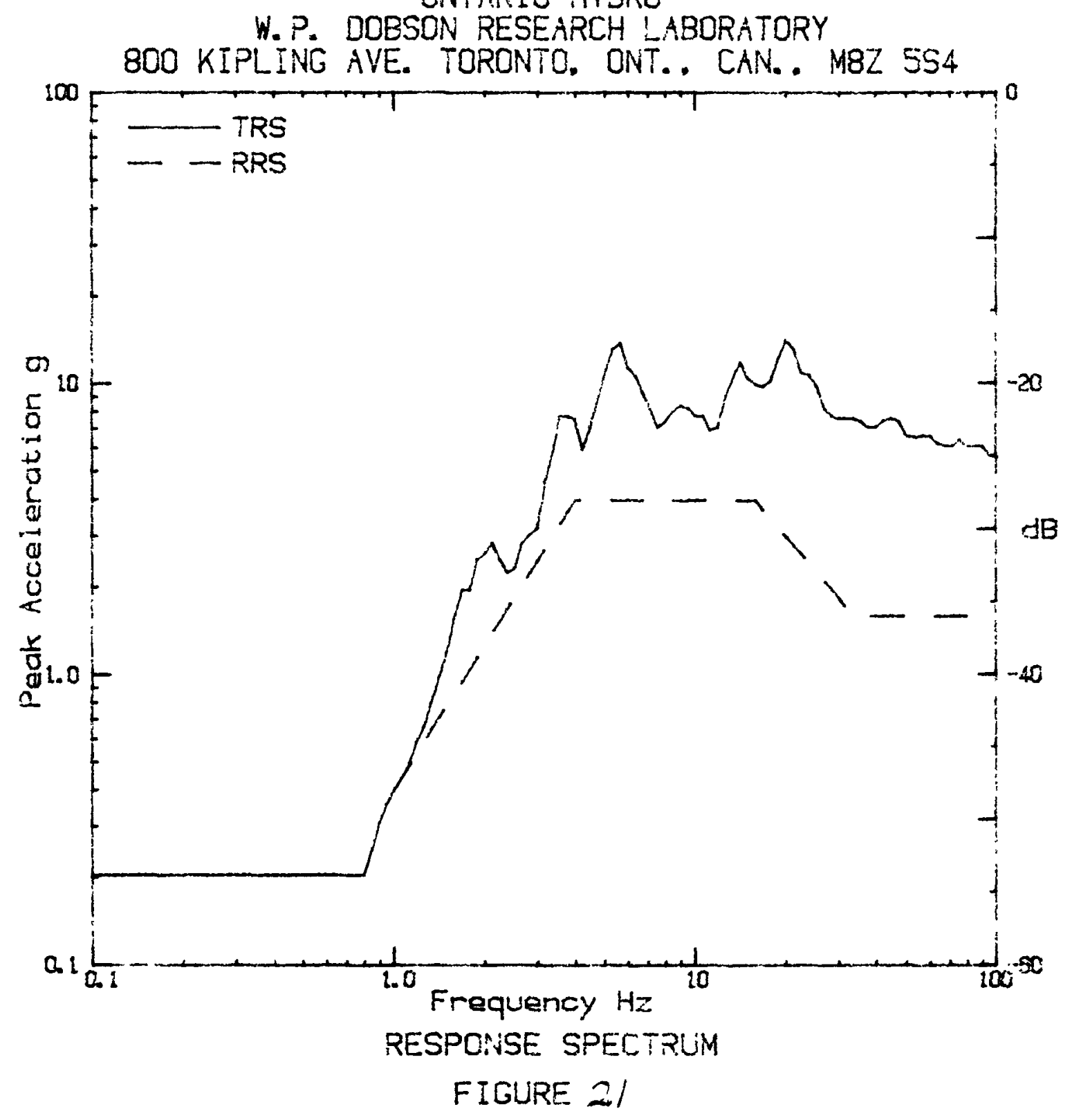

TEST ITEM

Station calis. Exida Model EMP 13. Serial 11.

PARTICULARS

March 14,84, Time 3: 00, Temp ('C) 23, Humidity (') 39.

Press (kPa) 100. 2. Graph 5125

SPECIFICATIONS

Specs IEEE 501. Conditions span 6. B, voitage \& current monitored

AIALYSIS

Type Maximax. Damping (\%5. B. $W_{0}=1 / 12$ Dctaves, Axis $Y_{\text {. }}$

Shaker tri-axial. $Z P X=1.599$

ACCELEROMETER

Wilcoxan. Serial 5761. Range dB58. Location base-mounting jig. 


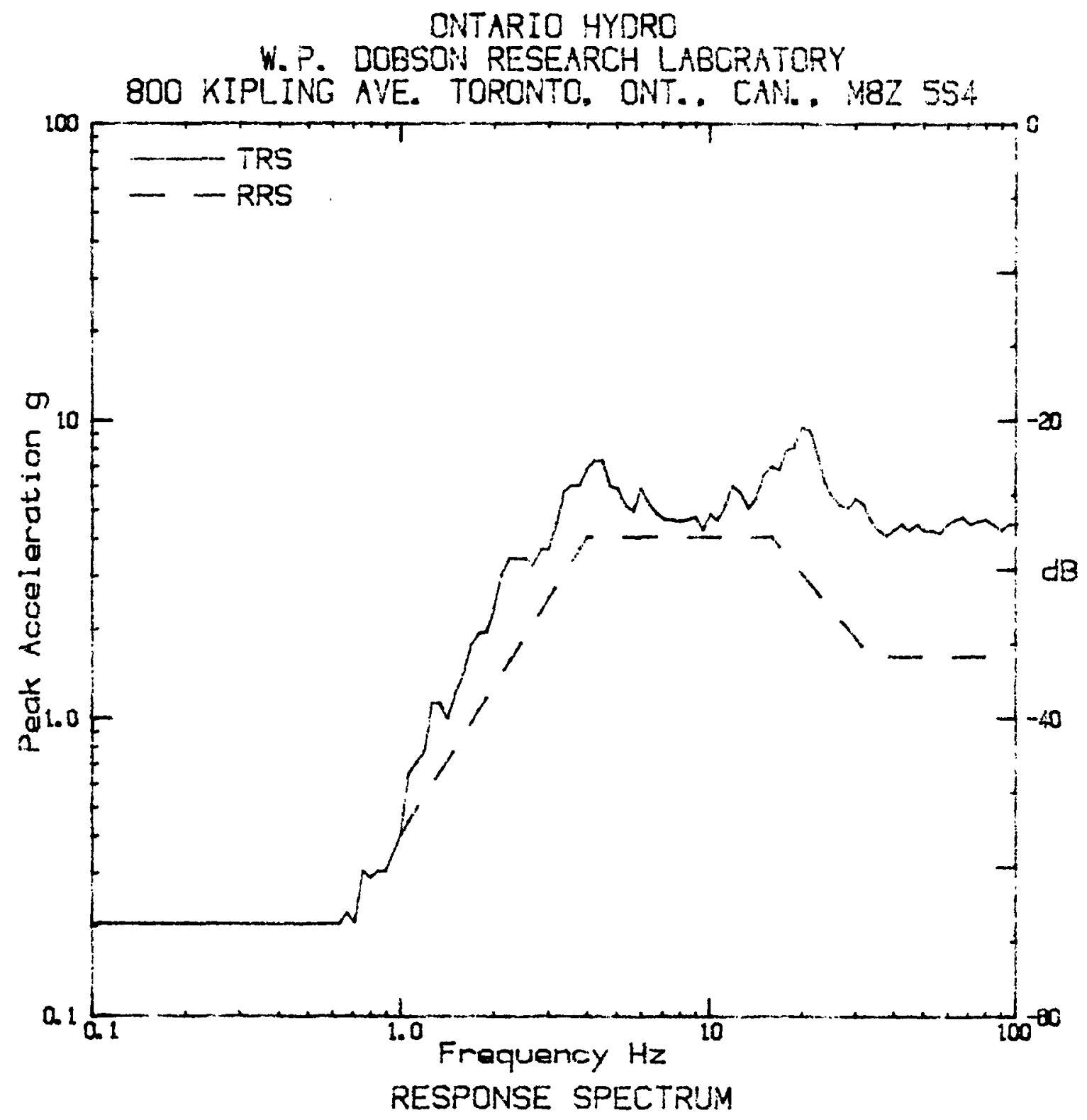

FIGURE 22

TEST ITEM

Station calls. Exicie, Modal EMP 13. Sarial 11.

PARTICULARS

March 14/84, Time 3:D0. Tamp('C) 23. Humidity $(\infty)$ 39.

Press (kPa) ioo.2. Graph 5130

\section{SPECIFICATIONS}

Spece IEEE 501. Conditions span E.8, vol tage 2 current manitored ANALYSIS

Type Haximax. Damping (a) 5. B. $\psi_{0}=1 / 12$ Coteves, Axis $Z$ Shoker tri-cxial. ZPM=1.63g

ACCELEROMETER

Wilcoxon. Seriai 5901 . Range dBSB, Location bose-mounting jig. 


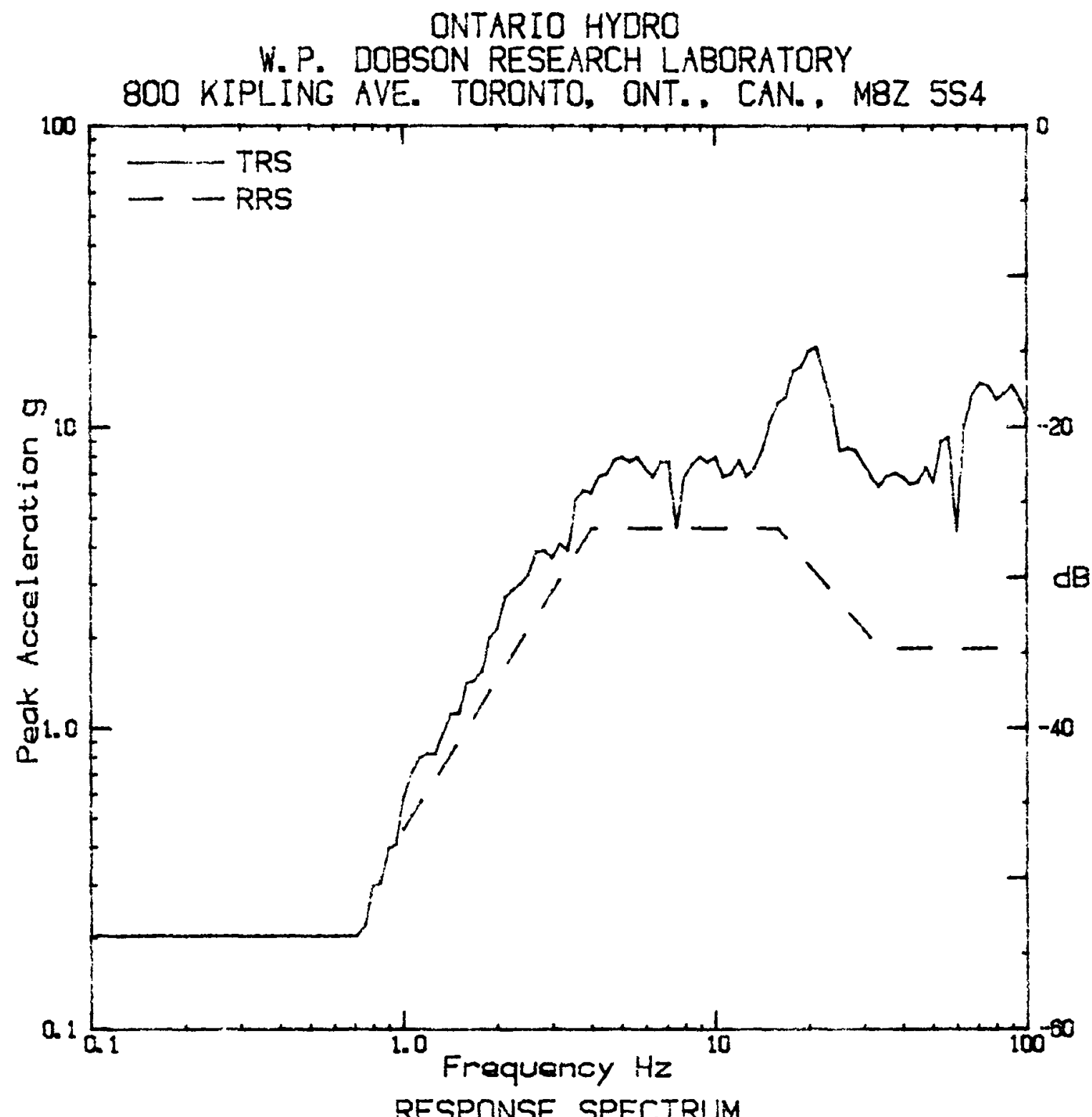

RESPONSE SPECTRUM

FIGURE 23

TEST ITEM

Station cella. Exida. Modal EMP 13. Sorial 11.

PARTICULARS

March 14/84, Time 3: 00, Tamp('C) 23, Humidity(

Press (kPa) 10C. 2. Graph 5131

SPECIFICATIONS

Specs IEEE 50i. Conditions span 6.8, voitoge \& current monitored

ANAL_YSIS

Type Waximax, Jamping (a) 5. B. W. $=1 / 12$ Octaves, Axis $X_{0}$

Shaker tri-axiai. $Z . P X=1.85 g$

ACCELERGMETER

Wilcoxon. Serial S771. Range dB58, Location top-cell tarminal.

TT 730. Channel 4 


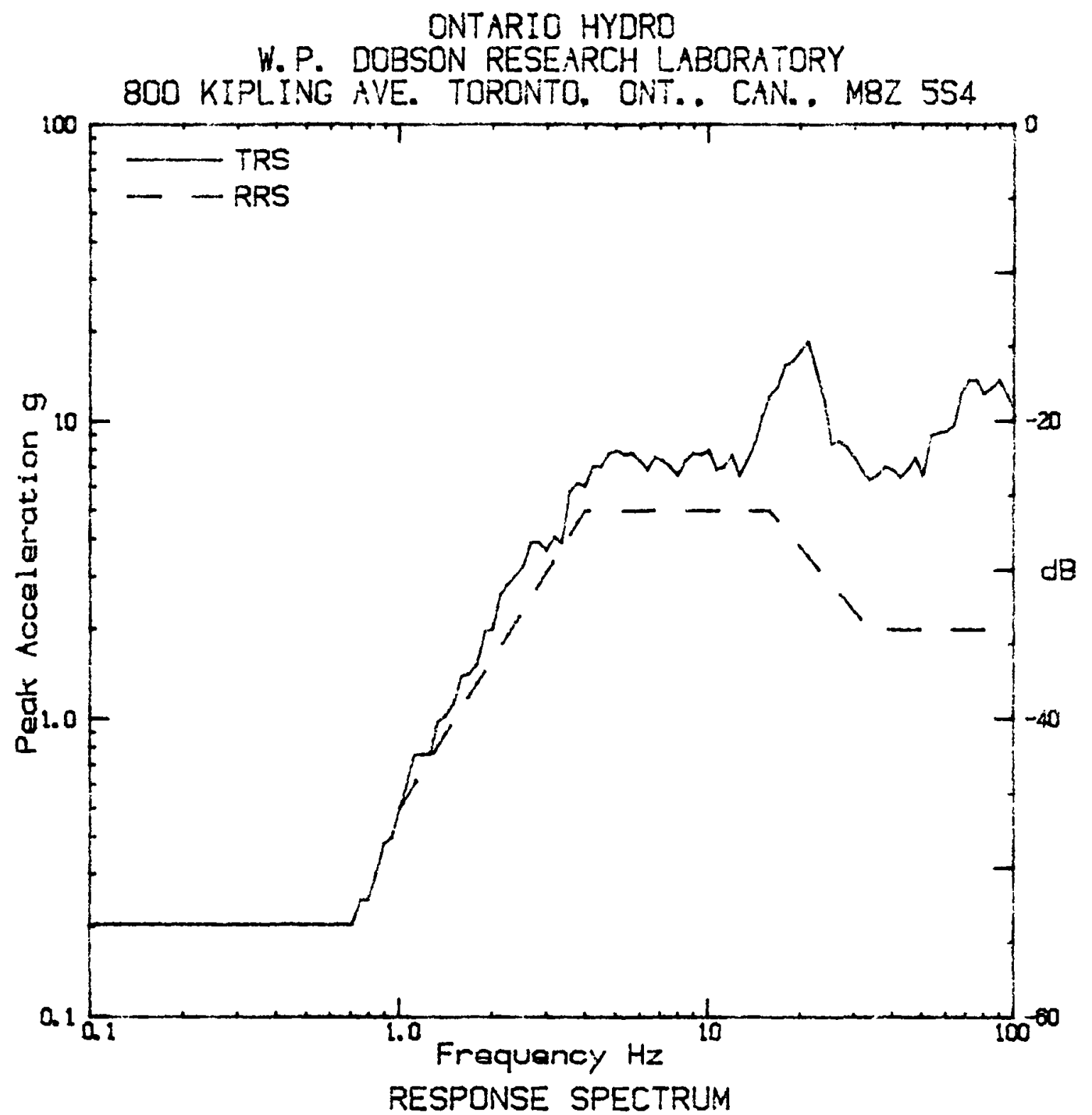

FIGURE if

\section{TEST ITEM}

Station cells. Exide, Madel EMP 13. Serial 11.

PARTICULARS

March 14/84, Time 3,00. Tomp('C) 23. Humidity(') 39.

Prass (kPa) 100.2. Graph 5132

SPECIFICATIONS

Specs IEEE 501. Conditions epan 6.8. voltage 8 current monitorad ANALYSIS

Type Maximax, Damping (z) 5, B. Y. = $1 / 12$ Cctoves, hxis $Y_{0}$ Shaker tri $a x i a l, Z P X=2 g$

ACCELEROMETER

Wilcoxon. Serial S297. Range dB58, Lacation top-cell terminal. TT 730. Channel 5 


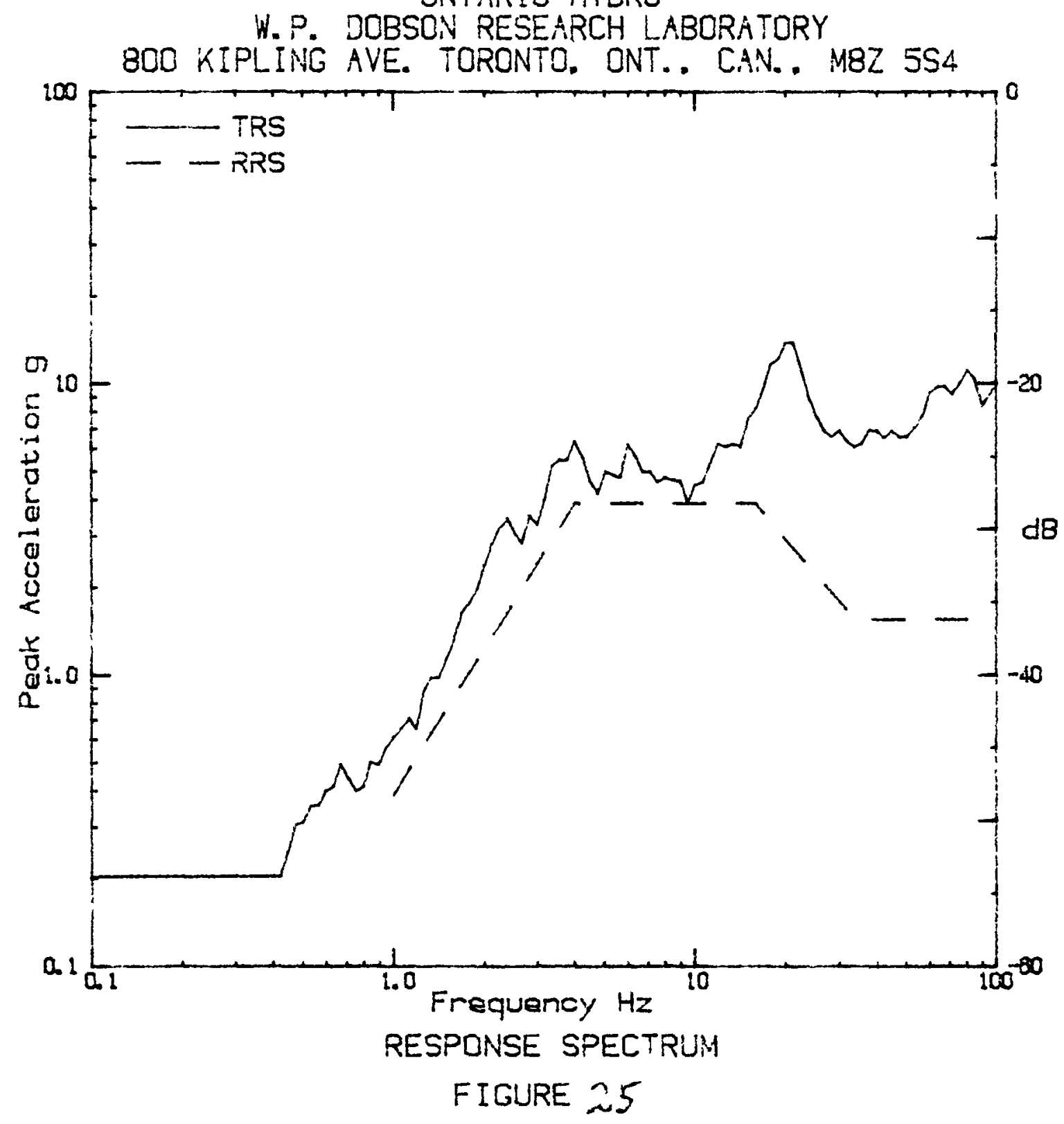

TEST ITEM

Station cells. Exida. Modal EMP 13. Serial 11.

PARTICLLLARS

March 14;84. Time 3800. Tamp ('C) 23. Humidity $(\theta) 39$.

Press (kPa) 100. 2. Graph 5133

SPECIFICATIONS

Spece IEEE 501. Conditions span 6.8. voltage \& current monitorad

ANALYSIS

Type Maximax. Damping (Z) 5, B. W. = 1/12 Detaves. Axis Z.

Shaker tri-axiel. $Z P K_{=1.56 \mathrm{~g}}$

ACCELEROMETER

Vilcoxon Serial S754. Range dB58. Location top-cell terminal. iT 730, Chemnel 6 
APPENDIX D

Seismic Testing of

Aged Shippingport Nuclear Power Plant Batteries
D. A. Black
G. D. Paulsen

Ontario Hydro Reaserach Division 
To Mr. B.A. Oliver

Manager

Electrical Design

Design \& Development

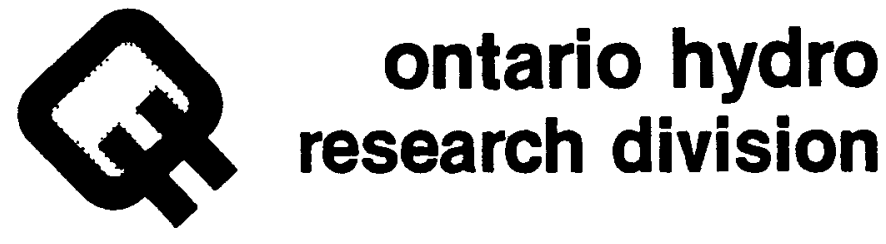

SEISMIC TESTING OF AGED

SHIPPINGPORT NUCLEAR POWER PLANT BATTERIES

D.A. Black and G.D. Paulsen

Five exide batteries removed from the Shippingport

Nuclear Power Plant were seismically tested to

IEEE Specifications. This report describes the test equipment used, the test procedure followed and gives the results of the tests.

\subsection{INTRODUCTION}

The five cells were tested together in a simulated rack. The assembly was tested to IEEE $344 / 1$ / and IEEE 501/2/ Specifications. Date of test, specimen description, test facility name and location, test data and test temperature, humidity and pressure are recorded on each of the response spectrum curves. These curves also show the conditions of the test, the type of analysis, the accelerometers used, the direction of the test, and the axis analysed. All tests were analysed using $5 \%$ damping and the maximax shock spectrum. The tests performed were tri-axial tests as defined in IEEE 344. The shaker inputs were pseudo-random with a duration of $30 \mathrm{~s}$. All technical terms used in this report are defined by Harris/3/.

\subsection{SAMPLES}

The station cells supplied for testing were naturally aged for a period of 27 years. They were ldentified as follows:

Exide; Model EMP-13; Serial No 43, 10, 4, 3, 45

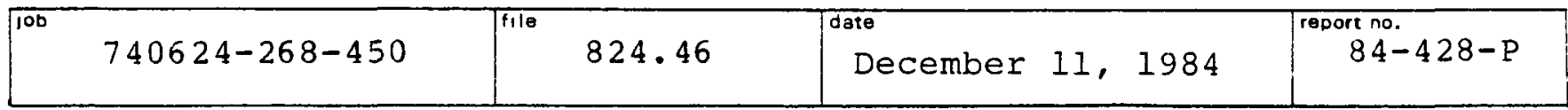




\subsection{TEST EQUIPMENT}

3.1 Equipment Used

3.1.1 Shaker Control Equipment

1. MTS 436 control units

2. MTS 406.11 controllers

3 MTS hydraulic pumps

4. Ontario Hydro noise generators and filters

5. Ontario Hydro tri-axial shaker table.

\section{1 .2 Analysis}

1. Columbia Model 9000 amplifiers and matching Wilcoxon M-408 accelerometers.

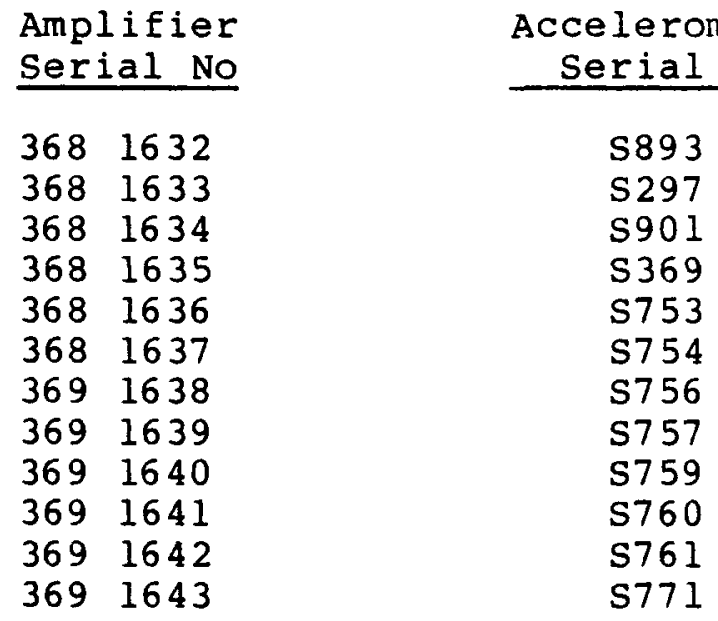

2. SE tape recorder Model 7000A, Serial No 547.

3. Tektronix 5113 dual beam storage oscilloscope, KS3681.

4. Spectral Dynamics 13231 Shock Spectrum Analyser, Serial No 27.

5. Spectral Dynamics 13191 Transient Memory, Serial No 29.

6. Ontario Hydro transmissibility circuit.

7. Watanabe WX4400 X-Y Recorder, Serial No 83010070 .

8. Hewlett-Packard 7046A X-Y1-Y2 Recorder, Serial No $1914 \mathrm{~A} 05842$.

9. Spectral Dynamics 50121L Tracking Filter, Serial No 171 . 
10. Spectral Dynamics SDI22L Tracking Filter, Serial No 370 .

11. Honeywell 1858 oscillograph, Serial No 2649 JF78.

12. Nicolet Scientific Corp, Model 660A Dual Channel EFT Analyzer, Serial No 9866226 .

13. Hewlett-Packard Model 7470A Plotter, Serial No $2210 A-12990$.

\subsubsection{Calibration Equipment}

1. Bruel and Kjaer Type 3506, Serial No 877022 Accelerometer Calibration set which includes Type 2626, Serial No 842947 and Type 83055, Serial No 858627, traceable to NBS.

2. General Radio 1557-A vibration calibrator, Serial No 2379.

3. Data Precision 2440 digital voltmeter, Serial No 5733 , traceable to NBS.

4. Data Precision 248 digital voltmeter, Serial No 8583 , traceable to NBS.

4.0 TESTS AND PROCEDURES

\subsection{Calibration procedure}

Accelerometers and amplifiers are calibrated using the back-toback calibration procedure. The reference accelerometer was mounted on the vibration calibrator with the wilcoxon accelerometer. Using $100 \mathrm{~Hz}$ sine wave vibration of approximately $\mathrm{l} \mathrm{g}$, the sensitivity of the Columbia amplifiers was set to give 500 $\mathrm{mV} / \mathrm{g}$ output. The outputs were measured using the digital voltmeter. By using the same voltmeter for both the reference and the Columbia amplifiers, slight differences in voltmeters need not be considered. Since the voltmeter measures true RMS voltages, the waveshapes of the $100 \mathrm{~Hz}$ signals were compared on the oscilloscope. This ensures that the signals are equivalent.

\subsection{Test Setup and Procedures}

The cells were mounted in a rack similar in design to the ones used in the Fitzpatrick NPP. All five cells were loaded and the current and voltage monitored by the Chemical Department/4/. The mounting arrangement is shown in Figure 0lA. A test history is given in Table II. 


\subsection{Vibration Tests}

The shaker consists of random generators and hydraulic actuators which are capable of driving the shaker in three directions simultaneously. The shaker has the following limitation in each axis:

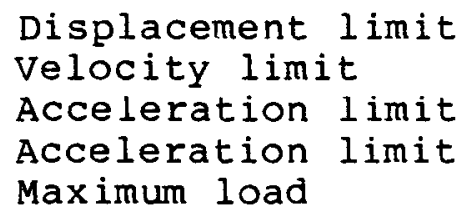

Displacement limit Acceleration limit Maximum load

$$
\begin{aligned}
& 152 \mathrm{~mm} \\
& 820 \mathrm{~m} / \mathrm{s} \\
& 4 \mathrm{~g} \mathrm{(no} \mathrm{load)} \\
& 1.6 \mathrm{~g} \mathrm{(fully} \mathrm{loaded)} \\
& 2000 \mathrm{~kg}
\end{aligned}
$$

Simultaneous random inputs were applied in three axes and the coherence between axes was negligible. The vibration levels in the two horizontal and vertical directions were individually controlled to nominally give similar levels. These levels were set by adjusting a "span" potentiometer. The span setting used is of no significance in itself except equivalent span settings nominally indicate equivalent vibration levels. The vibration is never the same from one test to the next since a different random signal is used for each test.

\subsection{RESULTS}

The test results are given in Figures 01B through 06. The batteries had a minimum standard $2 \mathrm{PA}$ for each direction as shown in Table I. A table of $2 \mathrm{PA}$ 's and equivalent span levels is given in Table III.

\section{CONCLUS IONS}

The five batteries tested experienced no structural or electrical damage as a result of the tests.

Approved :

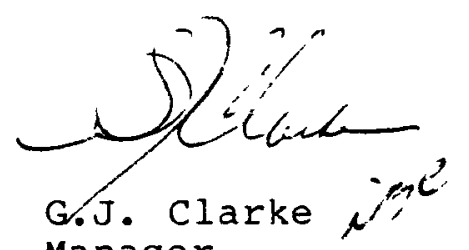

Manager

Mechanical Research Dept

\section{Submitted:}
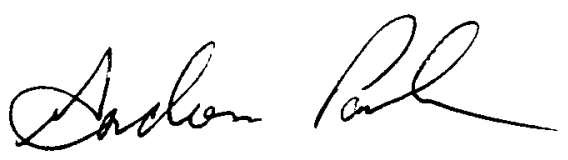

G. D. PaulserlaE

Technologist

Mechanical Testing and

Development Section

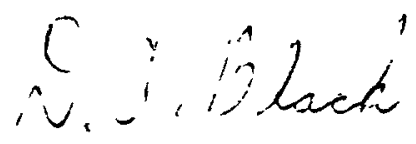

D.A. Black

Eng i neer

Mechanical Testing and

Development section

GDP : DAB : $\mathbf{s f}$ 


\section{REFERENCES}

1. The Institute of Electrical and Electronic Engineers Inc. IEEE 344. Qualification of Class lE Equipment for Nuclear Power Generating Stations. New York. 1975.

2. The Institute of Electrical and Electronic Engineers Inc. IEEE 501. IEEE Recommended Practices for seismic Qualification of Relays.

3. Harris, Cyril M., and Charles E. Crede. "Shock and Vibration Handbook". Second Edition. McGraw Hill Book Company. Toronto. 1976 .

4. W.J. Janis. "Seismic Qualification of Shippingport NPP Batteries - Cell Inspection and Capacity Tests". Research Report C84-121-P. December, 1984. 
TABLE I

\section{TEST RESULTS}

Cell

Direction

2PA

$43,10,4,3,45$

X - Base

1.1

Y - Base

2.17

Z - Base

1.26

X - Top

1.31

$Y$ - Top

0.8

Z - Top

1.22

TABLE II

TEST HISTORY

$\begin{array}{lcccc}\text { Date } & \text { Time } & \text { Run } & \text { Span } & \text { Comments } \\ \text { July 26/84 } & 3: 03 & 1 & 4 & \\ 3: 04 & 2 & 5 & \\ 3: 06 & 3 & 6 & \text { No failure } \\ 3: 08 & 4 & 7 & \end{array}$

D -6- 
TABLE III

SPAN VS ZPA

Direction

$\mathrm{X}$

$\mathrm{Y}$

Z
Span

$$
\begin{aligned}
& 7 \\
& 6
\end{aligned}
$$

5

4

3

7

6

4

3

7

6

5

4

3
Average ZPA

1.31

1.11

0.86

0.75

0.63

1.91

1.46

0.90

0.72

0.55

1. 47

1.31

1.02

0.86

0.62 


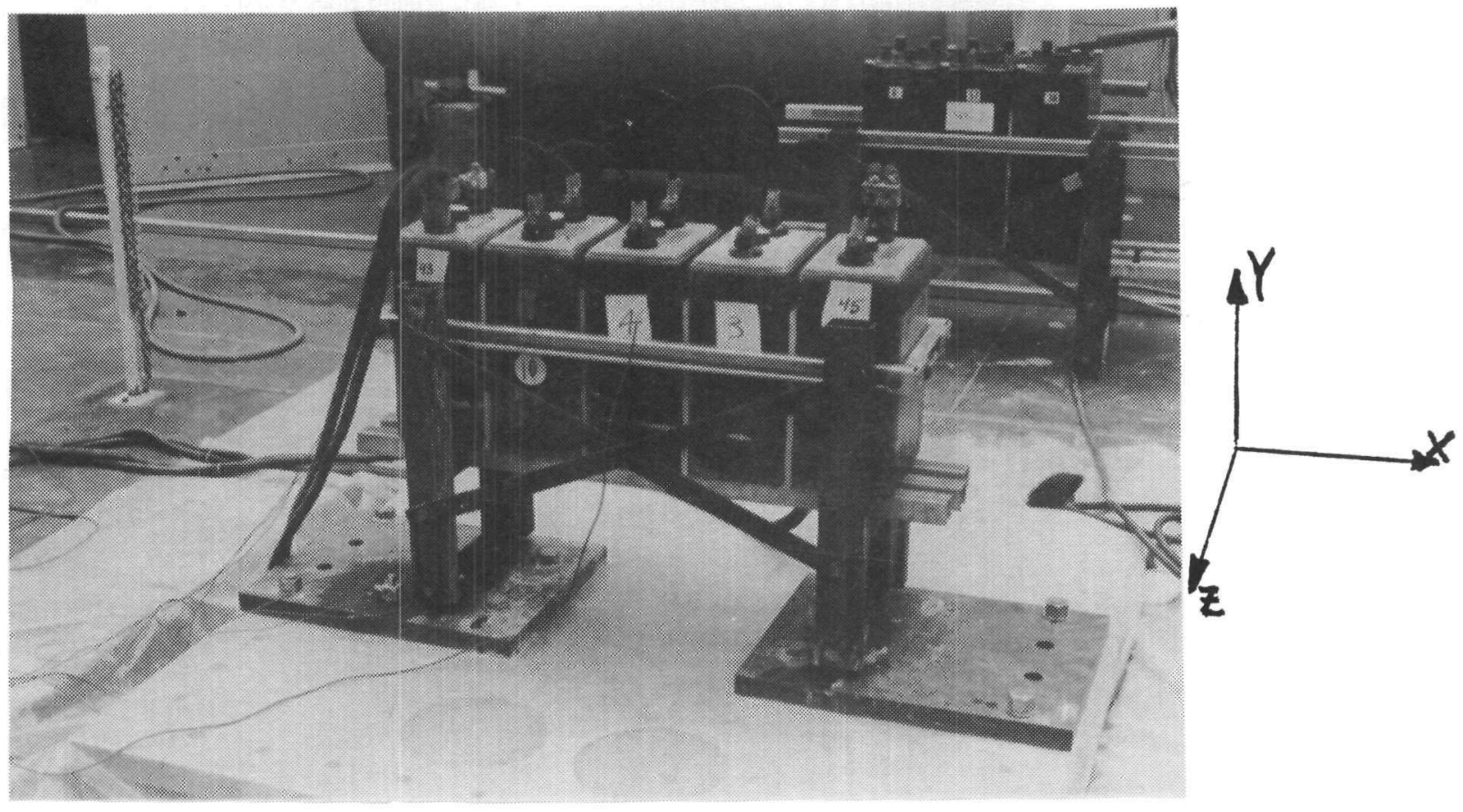

FIGURE 01A

THE FIVE EXIDE, MODEL EMP-13 BATTERIES WERE MOUNTED TO THE TRIAXIAL SHAKER TABLE AS SHOWN, ACCELEROMETERS WERE MOUNTED ON THE MOUNTING PLATES AND ON THE CELL TERMINAL FOR THE TEST. THE ACCELEROMETER DIRECTIONS ARE AS SHOWN. 


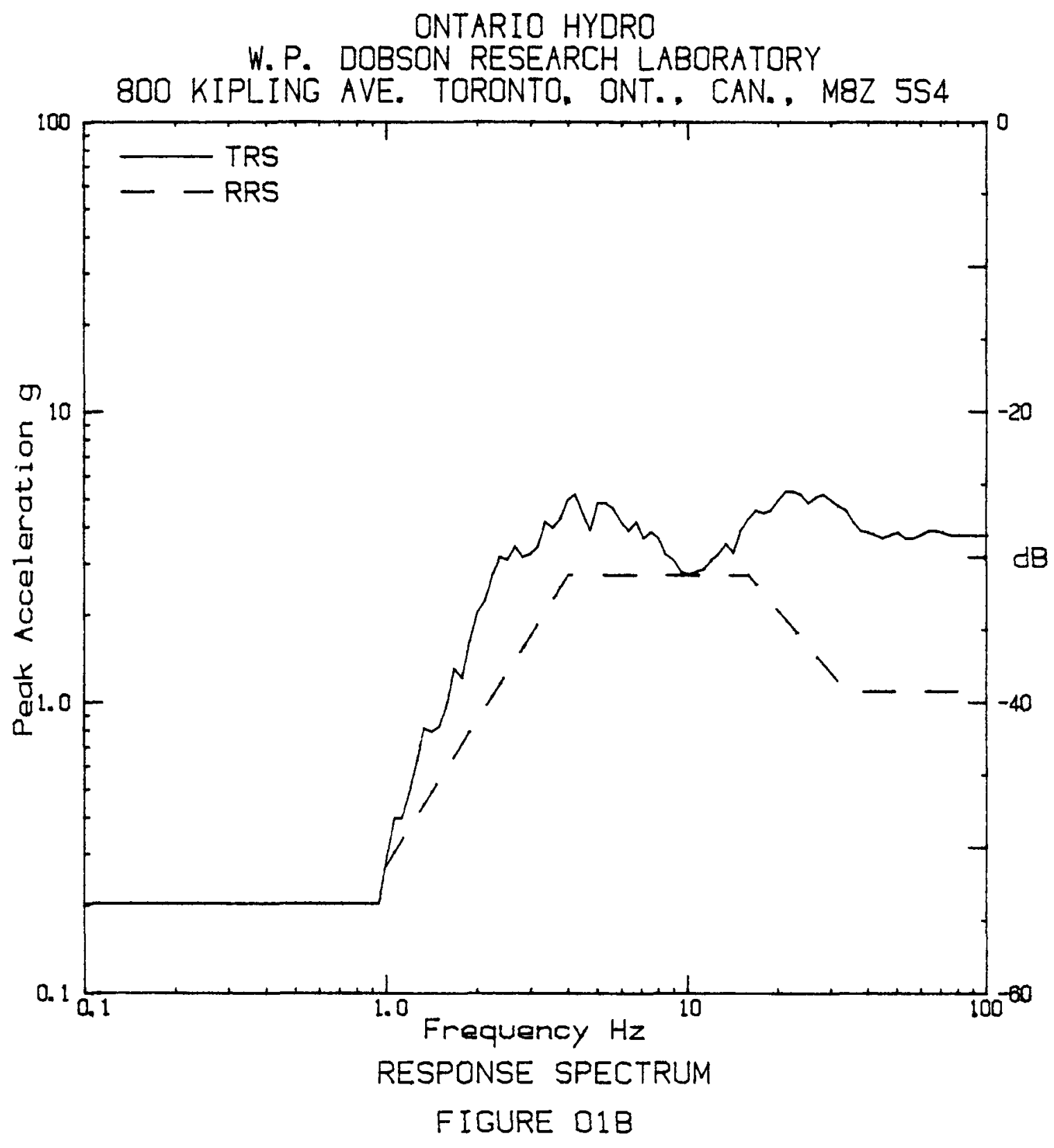

TEST ITEM

Station Cells \& Rack. Exide. Model EMP-13. Serial 43.10,4,3. 45

PART ICULARS

July 26/84. Time 3808. Temp('C) 23. Humidity(z) 55. Press (kPa) 100. Graph 5260

SPECIFICATIONS

Specs IEEE 501. Conditions operating: 1 hour rate, span 7

ANALYSIS

Type Maximax. Damping (z) 5. B. W. $=1 / 12$ Octaves, $A x i$ is $X_{\text {. }}$

Shaker tri-axial. $Z P A=1.1 \mathrm{~g}$

ACCELEROMETER

Wilcoxon, Serial S297. Range dB49. Location base-mounting plate. Channel 1 


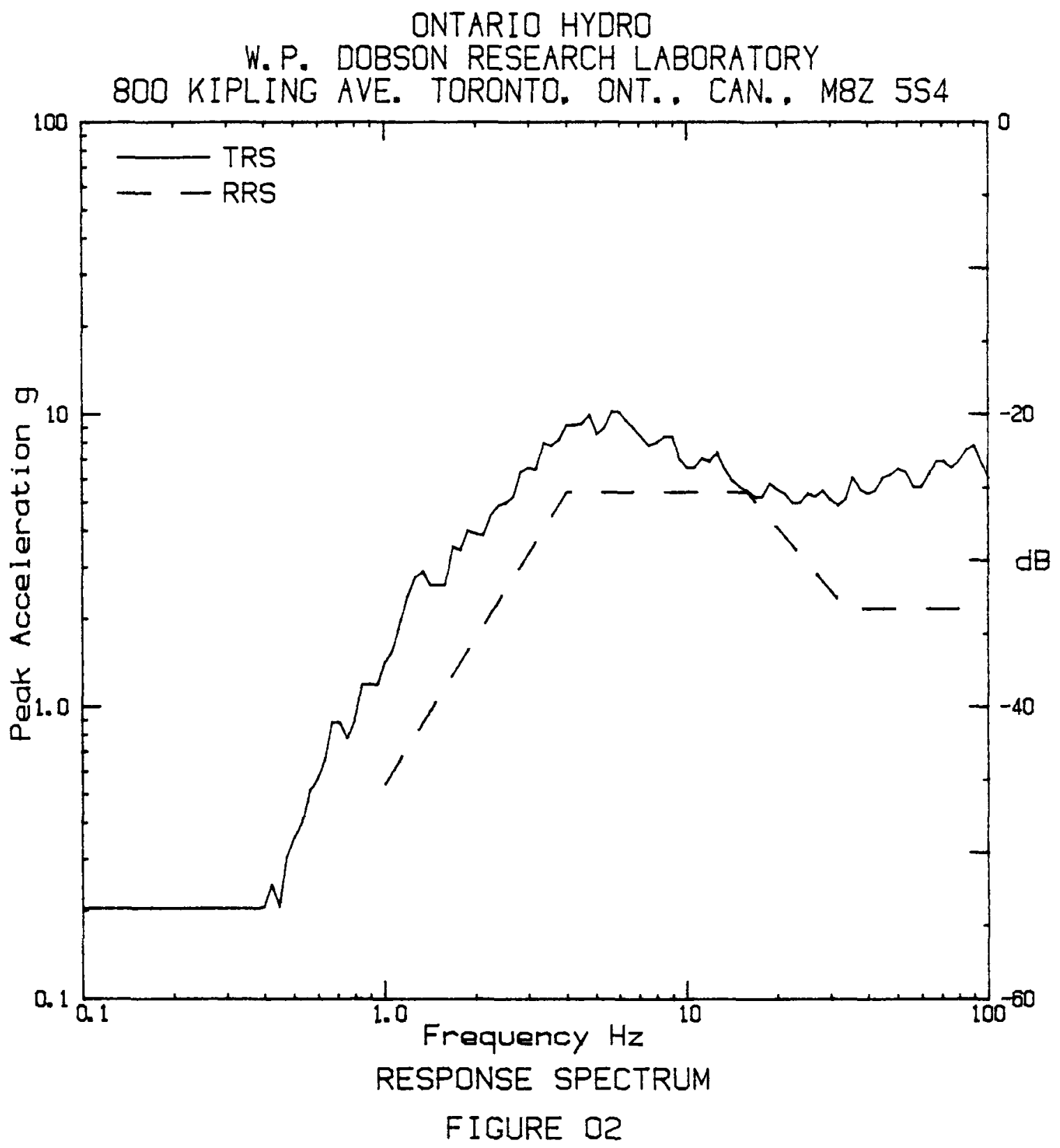

TEST ITEM

Station Cells \& Rack. Exide. Model EMP-13. Serial 43, 10, 4, 3, 45

PARTICULARS

July 26/84. Time 3: 08. Temp('C) 23. Humidity(\%) 55. Press (KPa) 100. Graph 5261

SPECIFICATIONS

Specs IEEE 501. Conditions operating : 1 hour rate, span 7

ANALYSIS

Type Maximax. Damping (Z) 5, B. W. $=1 / 12$ Detaves, Axis $Y$. Shaker tri-axial, ZPX $=2.17 \mathrm{~g}$

ACCELEROMETER

Wilcoxon, Serial S761. Range dB49, Location base-mounting plate. Channel 2 


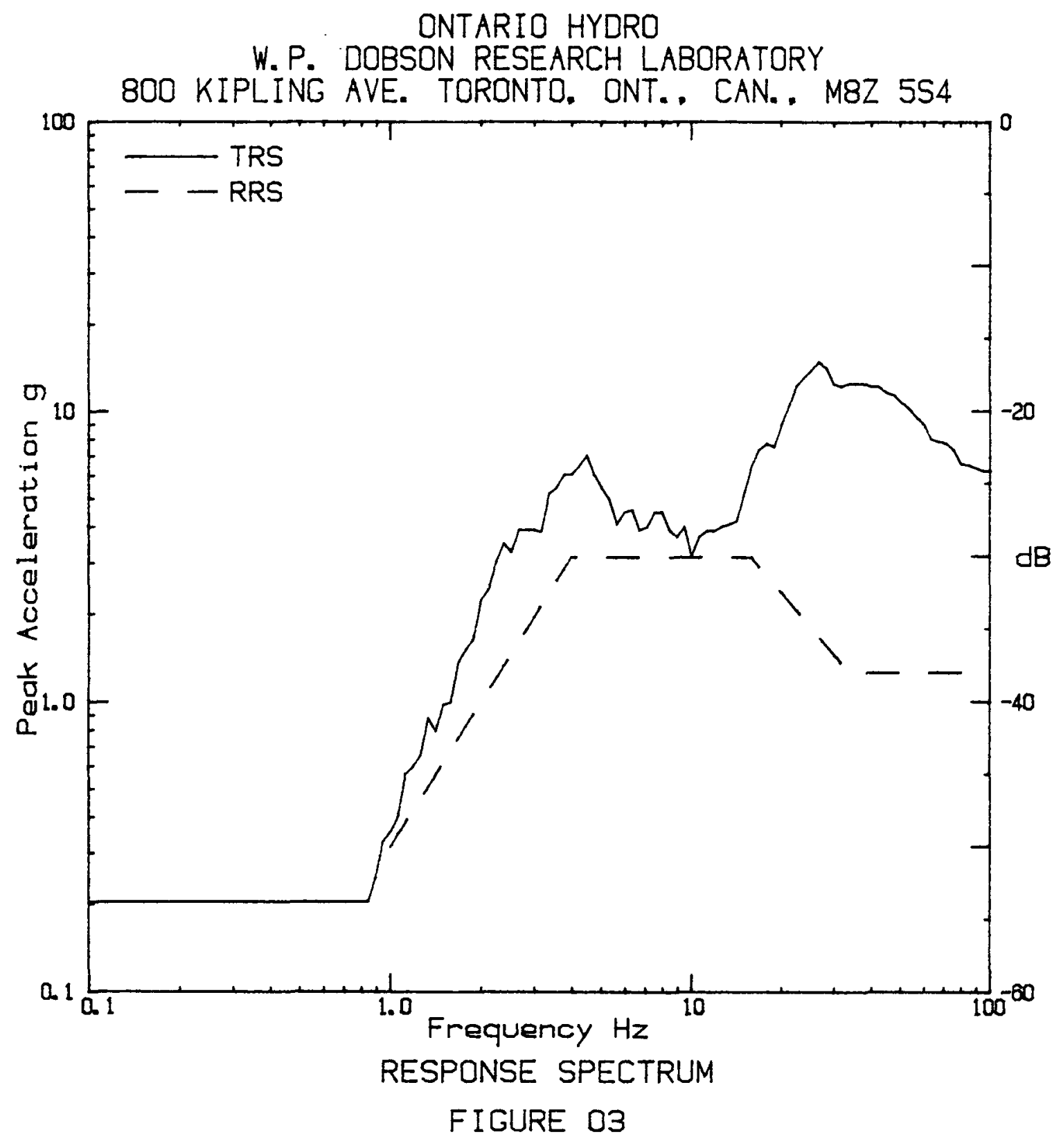

TEST ITEM

Station Cells \& Rack. Exide. Modal EMP-13, Serial 43, 10, 4, 3, 45

PARTICULARS

July 26/84, Time 3a 08. Temp ('C) 23. Humidity(\%) 55. Press (kPa) 100. Graph 5262

SPECIFICATIONS

Specs IEEE 501, Conditions operating: 1 hour rate, span 7

ANALYSIS

Type Maximax. Damping (z) 5, B. W. $=1 / 12$ Dctaves, Axis Z.

Shaker tri-axial, $Z P X=1.26 \mathrm{~g}$

ACCELEROMETER

Wilcoxon, Serial 5759. Range dB49. Location base-mounting plate. Channel 3 


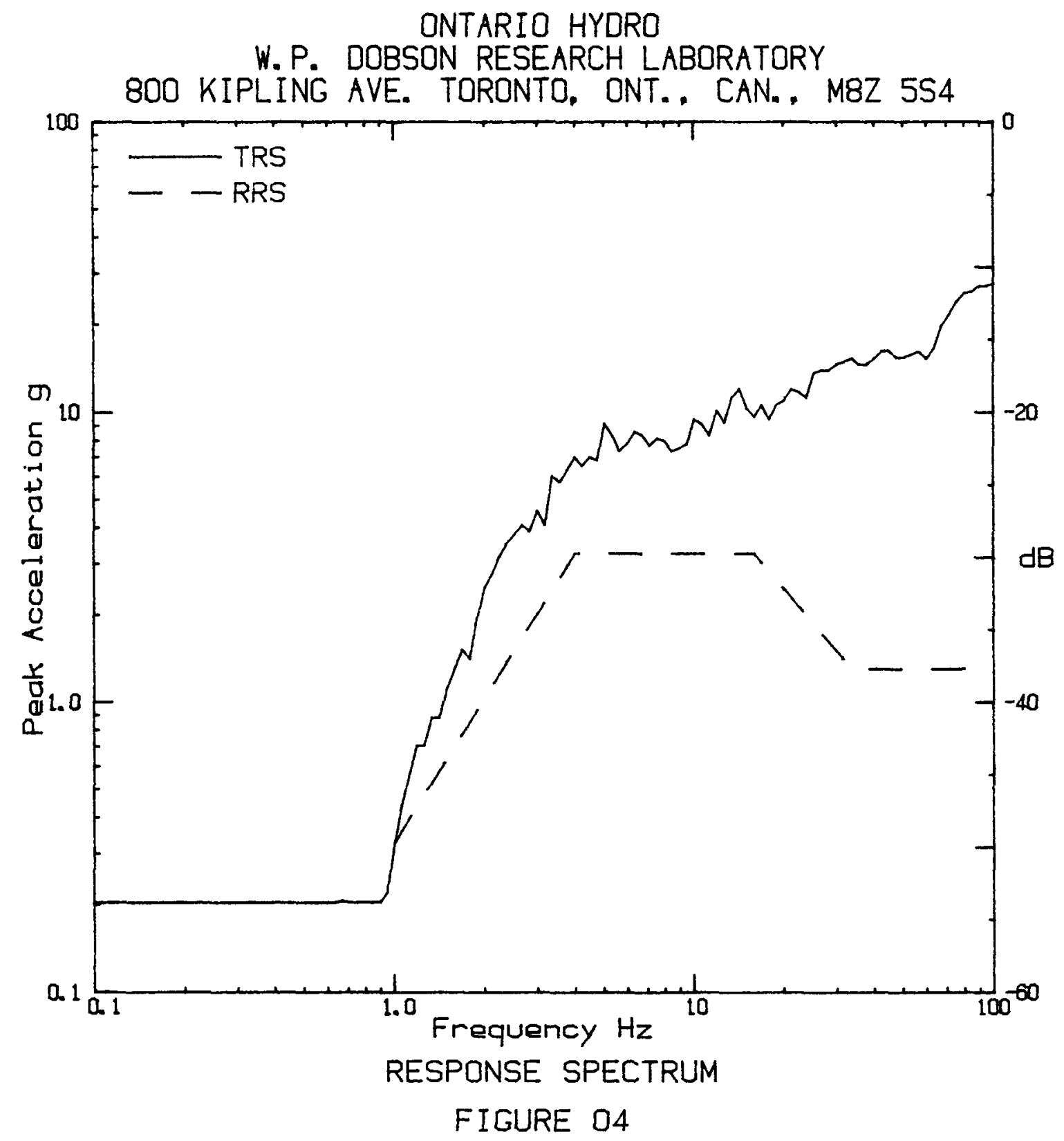

TEST ITEM

Station Cells \& Rack, Exide. Model EMP-13, Serial 43, 10, 4, 3, 45

PART ICULARS

July 26/84, Time 3:08, Temp('C) 23. Humidity(z) 55. Prass (kPa) 100. Graph 5263

SPECIFICATIONS

Specs IEEE 501. Conditions operating: 1 hour rate. span 7

ANALYSIS

Type Maximax. Damping (z) 5. B. $W_{*}=1 / 12$ Octaves, $A x i s X_{*}$ Shaker tri-axial. ZPX=1.31g

ACCELEROMETER

Wilcoxon. Serial 5901. Range dB49. Location top-cell terminal. Channel 4 


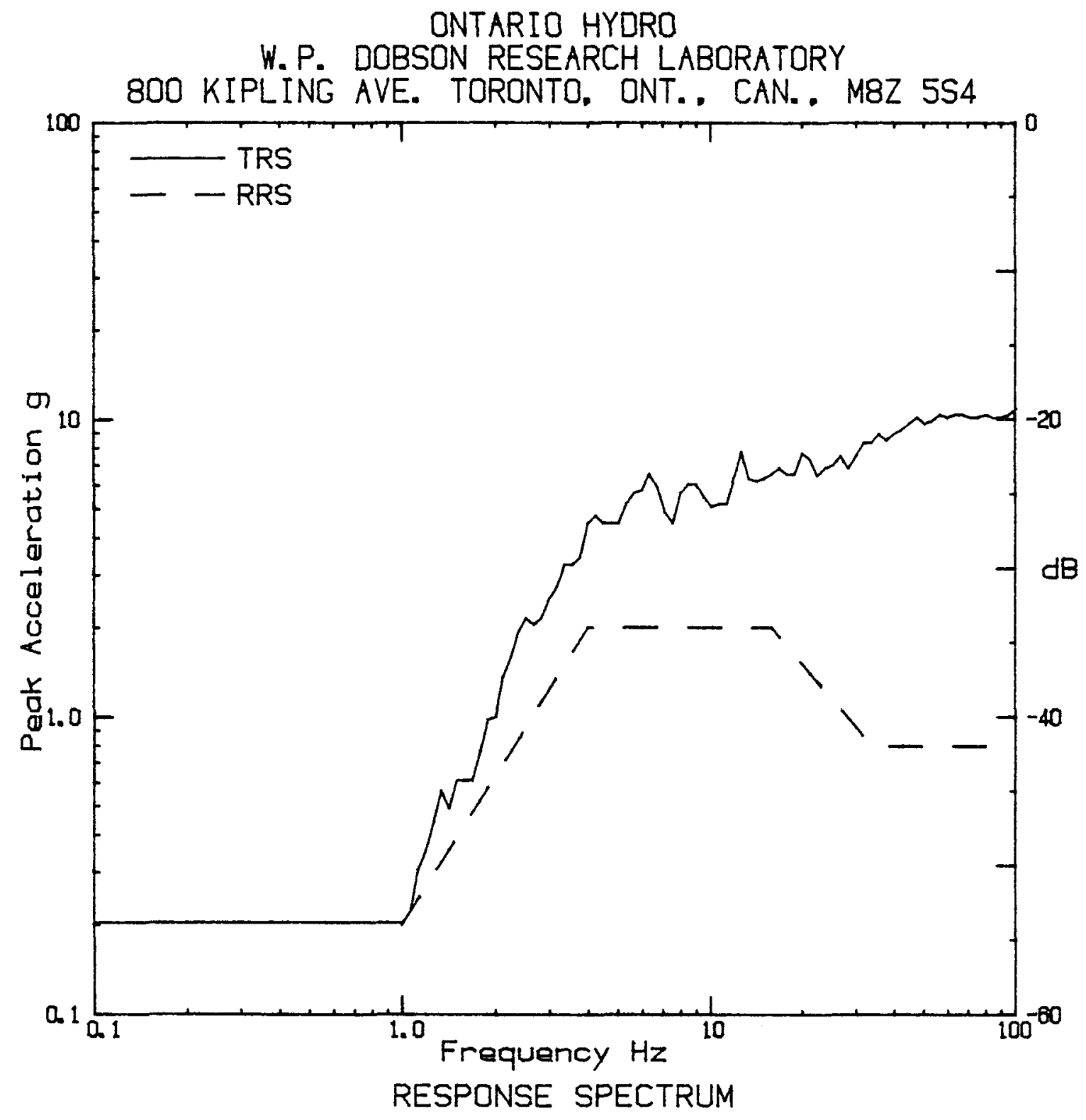

FIGURE 05

TEST ITEM

Station Cells \& Rack. Exide. Model EMP-13. Serial 43, 10,4.3, 45

PART ICULARS July 26/84. Time 3: 08. Temp ('C) 23. Humidity ( $(2)$ 55. Press (KPa) 100.

SPECIFICATIONS

Specs IEEE 501. Conditions operating: 1 hour rate, span 7

ANALYSIS

Type Maximax, Damping (z) 5. B. $W_{0}=1 / 12$ Octaves. Axis $Y_{0}$ Shaker tri-axial. ZPA $=.8 \mathrm{~g}$

ACCELEROMETER

Wilcoxon: Serial 5757. Range dB49, Location top-cell terminal, Channel 5 


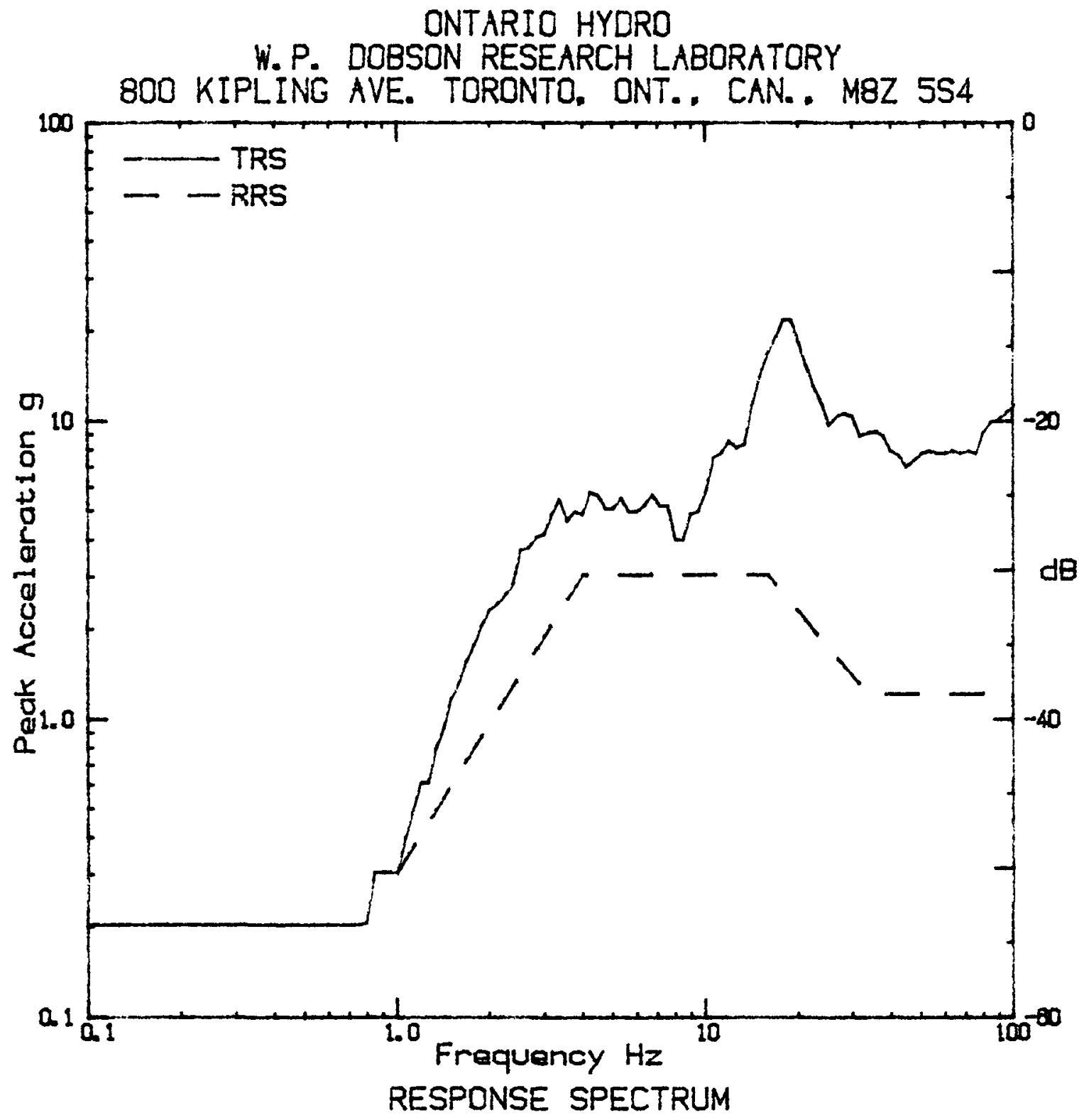

FIGURE OG

TEST ITEM

Station Calls \& Rack, Exide, Modal EMP-13, Serlal 43, 10, 4, 3, 45

PARTICULARS

July 26/84, Time 3a08. Tamp('C) 23. Humidity(x) 55. Pross (kPa) 100.

Graph 5263

SPECIFICATIONS

Spece IEEE 501. Conditions operating 1 hour rate. span 7

ANALYSIS

Type Maximax, Damping cos, B. $W_{0}=1 / 12$ Octaves, Axis Z.

Shaker tri-axial. ZPX $=1.22 \mathrm{~g}$

ACCELEROMETER

Wilcoxon, Sarial S969, Range dB49, Location top-call terminal. Channel 6 


\section{DISTRIBUTION :}

U.S. URC Distribution Contractor 15700 Crabbs Branch Way

Rockville, ID 20850

375 copies for RV

Ansaldo Impianti

Centro Sperimentale del Boschetto

Corso F.H. Perrone, 118

16161 Genova

ITALY

Attn: C. Bozzolo

Ansaldo Impianti

Via Gabriele D'Annunzio, 113

16121 Genova

ITALY

Attn: S. Grifoni

ASEA-ATOK

Department KRD

Box 53

s-721 04

Vasteras

SWEDEN

Attn: A. Kjellberg

ASEA-ATOM

Department TQD

Box 53

S-721 04

Vasteras

SWEDEN

Attn: T. Granberg

ASEA KABEL AB

P.0. BoX 42108

S-126 12

Stockholm

SWEDEN

Attn: B. Dellby

Atomic Energy of Canada, Ltd.

Chalk River Nuclear Laboratories Chalk River, Ontario KOJ $1 J 0$

CANADA

Attn: G. F. Lynch
Atomic Energy of Canada, Ltd. 1600 Dorchester Boulevard West Hontreal, Quebec H3H 1P9

CANADA

Attn: S. Wish

Atomic Energy Research Establishment Building 47, Division M.D.D.

Harwell, Oxfordshire

OXI1 ORA,

ENGLAND

Attn: S. G. Burnay

Bhabha Atomic Research Centre

Health Physics Division

BARC

Bombay-85

INDIA

Attn: S. K. Mehta

British Nuclear Fuels Ltd.

Springfields Works

Salwick, Preston

Lancs

EWGLAND

Attn: W. G. Cunliff, Bldg 334

Brown Boveri Reaktor GKBH

Postfach 5143

D-6800 Mannheim 1

WEST GERMANY

Attn: R. Schemmel

Bundesanstalt fur Materialprufung

Unter den Eichen 87

D-1000 Berlin 45

WEST GERMANY

Attn: $K$. Wundrich

CEA/CEN-FAR

Departement de Surete Nucleaire Service d'Analyse Fonctionnelle

B.P. 6

92260 Fontenay-aux-Roses

FRANCE

Attn: H. Le Meur

$\mathrm{J}$. Henry 
CERA

Laboratorie 1

CH-1211 Geneve 23

SWITZERLAND

Attn: H. Schonbacher

Canada Wire and Cable Limited

Power \& Control Products Division

22 Commercial Road

Toronto, Ontario

CANADA M4G 1Z4

Attn: Z. S. Paniri

Centro Elettrotecnico

Sperimentale Italiano

Research and Development

Via Rubattino 54

20134 Milan,

ITALY

Attn: Carlo Masetti

Commissariat a $1^{\prime}$ Energie Atomique

ORIS/LABRA

BP $\mathrm{N}^{\circ} 21$

91190 Gif-Sur-Yvette

FRANCE

Attn: G. Gaussens

$\mathrm{J}$. Chenion

F. Carlin

Commissariat a l'Energie Atomique CEN Cadarche DRE/STRE

BP $\mathrm{N}^{\circ} 1$

13115 Saint Paul Lez Durance

FRANCE

Attn: J. Campan

Conductores Monterrey, S. A.

P.O. Box 2039

Monterrey, N. L.

MEXICO

Attn: P. G. Murga

Electricite de France

(S.E.P.T.E.N.)

12, 14.Ave. Dubrieroz

69628 Villeurbarnie

Paris, FRANCE

Attn: H. Herouard

H. Hermant
Electricite de France

Direction des Etudes et Recherches

1, Avenue du General de Gaulle

92141 CLAMART CEDEX

FRANCE

Attn: J. Roubault

L. Deschamps

Electricite de France

Direction des Etudes et Recherches

Les Renardieres

Boite Postale $n^{\circ} 1$

77250 KORET SUR LORING

FRANCE

Attn: Ph. Roussarie

V. Deglon

J. Ribot

EURATOM

Commission of European Communities

C.E.C. J.R.C.

21020 Ispra (Varese)

ITALY

Attn: G. Mancini

ERAMATOME

Tour Fiat - Cedex 16

92084 Paris La Defense

FRANCE

Attn: G. Chauvin

E. Raimondo

Furukawa Electric Co., Ltd.

Hiratsuka Wire Works

1-9 Higashi Yawata - 5 Chome

Hiratsuka, Kanagawa Pref

JAPAN 254

Attn: E. Oda

Gesellschaft fur Reaktorsicherheit (GRS) $\mathrm{mbH}$ Glockengasse 2

D-5000 Koln 1

WEST GERMANY

Attn: Library

Health \& Safety Executive

Thames House North

Milbank

London SWIP 4QJ

ENGLAND

Attn: W. W. Ascroft-Hutton 
ITT Cannon Electric Canada

Four Cannon Court

Whitby, ontario L1N 5 V8

CANADA

Attn: B. D. Vallillee

Imatran Voima oy

Electrotechn. Department

P.0. Box 138

SF-00101 Helsinki 10

FINLAND

Attn: B. Regnell

K. Koskinen

Institute of Radiation Protection Department of Reactor Safety

P.0. Box 268

00101 Helsinki 10

FINLAND

Attn: L. Reiman

Instituto de Desarrollo y Diseno

Ingar - Santa Fe

Avellaneda 3657

c.C. $34 \mathrm{~B}$

3000 Santa $\mathrm{Fe}$

REPUBLICA ARGENTINA

Attn: N. Labath

Japan Atomic Energy Research Institute Takasaki Radiation Chemistry

Research Establishment

Watanuki-machi

Takasaki, Gunma-ken

JAPAN

Attn: N. Tamura

K. Yoshida

T. Seguchi

Japan Atomic Energy Research Institute Tokai-Mura

Yaka-Gun

Ibaraki-Ken

319-11

JAPAN

Attn: Y. Koizumi
Japan Atomic Energy Research Institute Osaka Laboratory for Radiation Chemistry 25-1 Mii-Minami machi,

Neyagawa-shi

Osaka 572

JAPAN

Attn: $Y$. Hakase

Kalle Niederlassung der Hoechst AG Postfach 3540

6200 Wiesbaden 1 ,

WEST GERMANY

Biebrich

Attn: Dr. H. Wilski

Kraf twerk Union AG

Department R361

Hammerbacherstrasse $12+14$

D-8524 Erlangen

WEST GERMANY

Attn: I. Terry

Kraftwerk Union AG

Section R541

Postfach: 1240

D-8757 Karlstein

WEST GERMANY

Attn: W. Siegler

Kraf twerk Union AG

Hammerbacherstrasse $12+14$

Postfach: 3220

D-8520 Erlangen

WEST GERHANY

Attn: W. Morell

Motor Columbus

Parkstrasse 27

CH-540I

Baden

SWITZERLAND

Attn: H. Fuchs

National Nuclear Corporation

Cambridge Road

Whetstone

Leicester LE8 3LH

ENGLAND

Attn: A. D. Hayward

J. V. Tindale 
HOK AG Baden

Beznau Wuclear Power Plant

CH-5312 Doettingen

SWITZERLAND

Attn: 0 . Tatti

Jorsk Kabelfabrik

3000 Drammen

NORWAY

Attn: C. T. Jacobsen

Wuclear Power Engineering Test Center 6-2, Toranomon, 3-Chome

Minato-ku

No. 2 Akiyana Building

Tokyo 105

JAPAN

Attn: K. Takumi

Ontario Hydro

700 University Avenue

Toronto, Ontario M5G 1X6

CANADA

Attn: $\mathbf{R}$. Wong

B. Kukreti

Oy strombers Ab

Helsinki Works

Box 118

FI-00101 Helsinki 10

FINLAND

Attn: P. Paloniemi

Radiation Center of Osaka Prefecture

Radiation Application-

Physics Division

Shinke-Cho, Sakai

Osaka, 593, JAPAN

Attn: S. Okamoto

Rappin1

ENEA-PEC

Via Arcoveggio $56 / 23$

Bologna

IIALY

Attn: Ing. Ruggero
Rheinisch-Westfallscher

Technischer Uberwachunge-Vereln e.v.

Postfach 103261

D-4300 Essen 1

WEST GERMANY

Attn: R. Sartori

Sydkraft

Southern Sweden Power Supply

21701 Malmo

SWEDEN

Attn: 0 . Grondalen

Technical University Hunich

Institut for Radiochemie

D-8046 Garching

WEST GERMANY

Attn: Dr. H. Heusinger

UKAEA

Materials Development Division

Building 47

AERE Harwell

OXON OXII ORA

ENGLAND

Attn: D. C. Phillips

United Kingdom Atomic Energy Authority

Safety \& Reliability Directorate

Wigshaw Lane

Culcheth

Warrington WA3 $4 \mathrm{NE}$

BNGLAND

Attn: M. A. H. G. Alderson

Waseda University

Department of Electrical Engineering

4-1 Ohkubo-3, Shinjuku-ku

Tokyo

JAPAN

Attn: K. Yahagi 


$\begin{array}{ll}1800 & \text { R. L. Schwoebel } \\ 1810 & \text { R. G. Kepler } \\ 1811 & \text { R. L. Clough } \\ 1812 & \text { L. A. Harrah } \\ 1812 & \text { K. T. Gillen } \\ 1813 & \text { J. G. Curro } \\ 2155 & \text { J. E. Gover } \\ 2155 & \text { O. M. Stuetzer } \\ 2525 & \text { R. P. Clark } \\ 2525 & \text { D. H. Bush } \\ 2525 & \text { J. L. Chamberlin } \\ 6200 & \text { V. L. Dugan } \\ 6300 & \text { R. W. Lynch } \\ 6400 & \text { A. H. Snyder } \\ 6410 & \text { J. W. Hickman } \\ 6417 & \text { D. D. Carlson } \\ 6420 & \text { J. V. Walker } \\ 6440 & \text { D. A. Dahlgren } \\ 6442 & \text { W. A. Von Riesemann } \\ 6444 & \text { L. D. Buxton } \\ 6446 & \text { L. L. Bonzon (35) } \\ 6446 & \text { W. H. Buckalew } \\ 6446 & \text { L. D. Bustard } \\ 6446 & \text { J. W. Grossman } \\ 6446 & \text { D. B. Hente } \\ 6446 & \text { E. H. Richards } \\ 6446 & \text { F. V. Thome } \\ 6446 & \text { F. J. Wyant } \\ 6447 & \text { D. L. Berry } \\ 6447 & \text { R. R. Bennett } \\ 6449 & \text { K. D. Bergeron } \\ 6450 & \text { J. A. Reuscher } \\ 8024 & \text { M. A. Pound } \\ 3141 & \text { C. H. Ostrander (5) } \\ 3151 & \text { W. L. Garner } \\ & \end{array}$




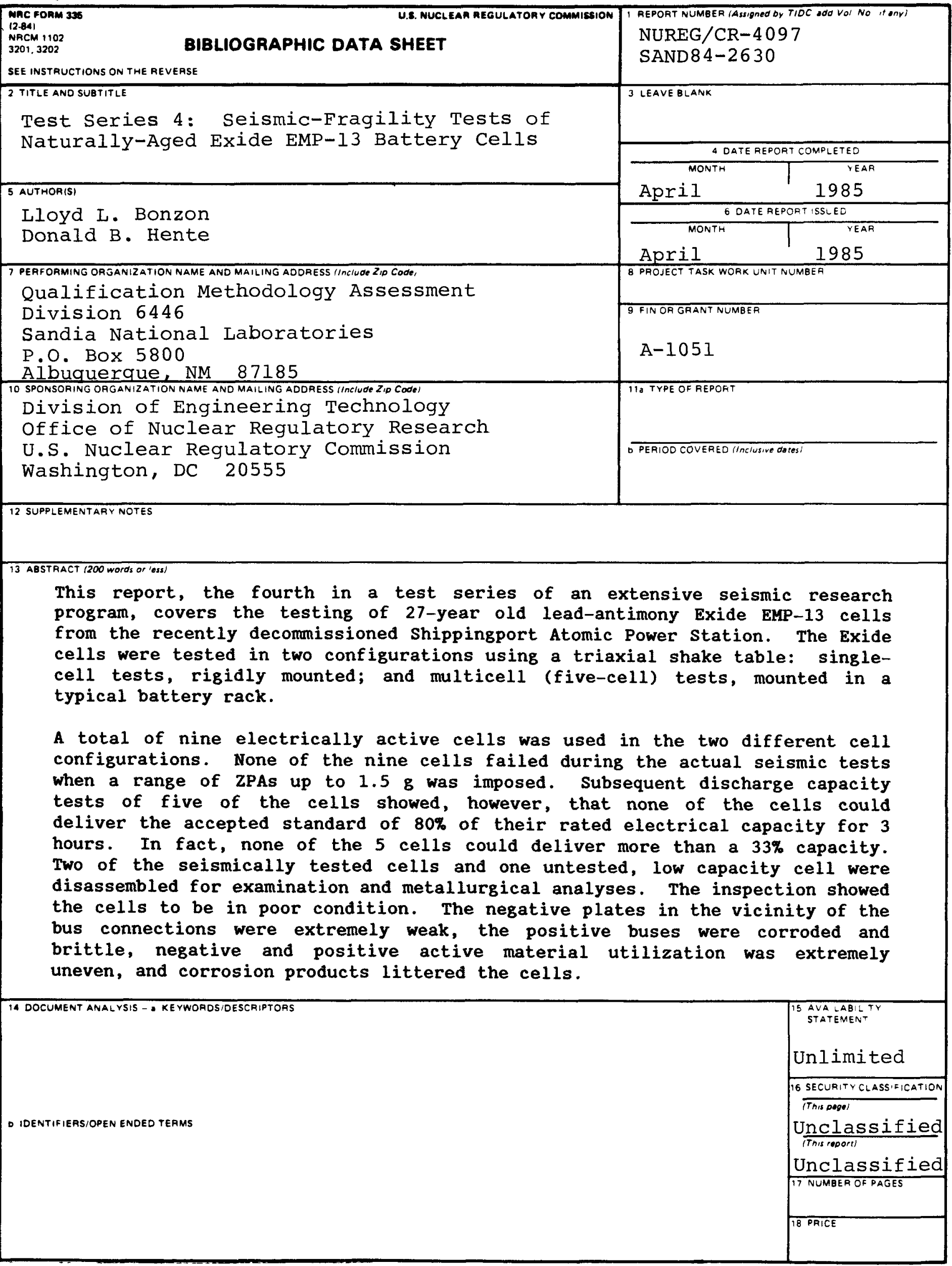

